\title{
[4] Agriculure
}

\section{Guide to the identification of plant macrofossils in Canadian peatlands}
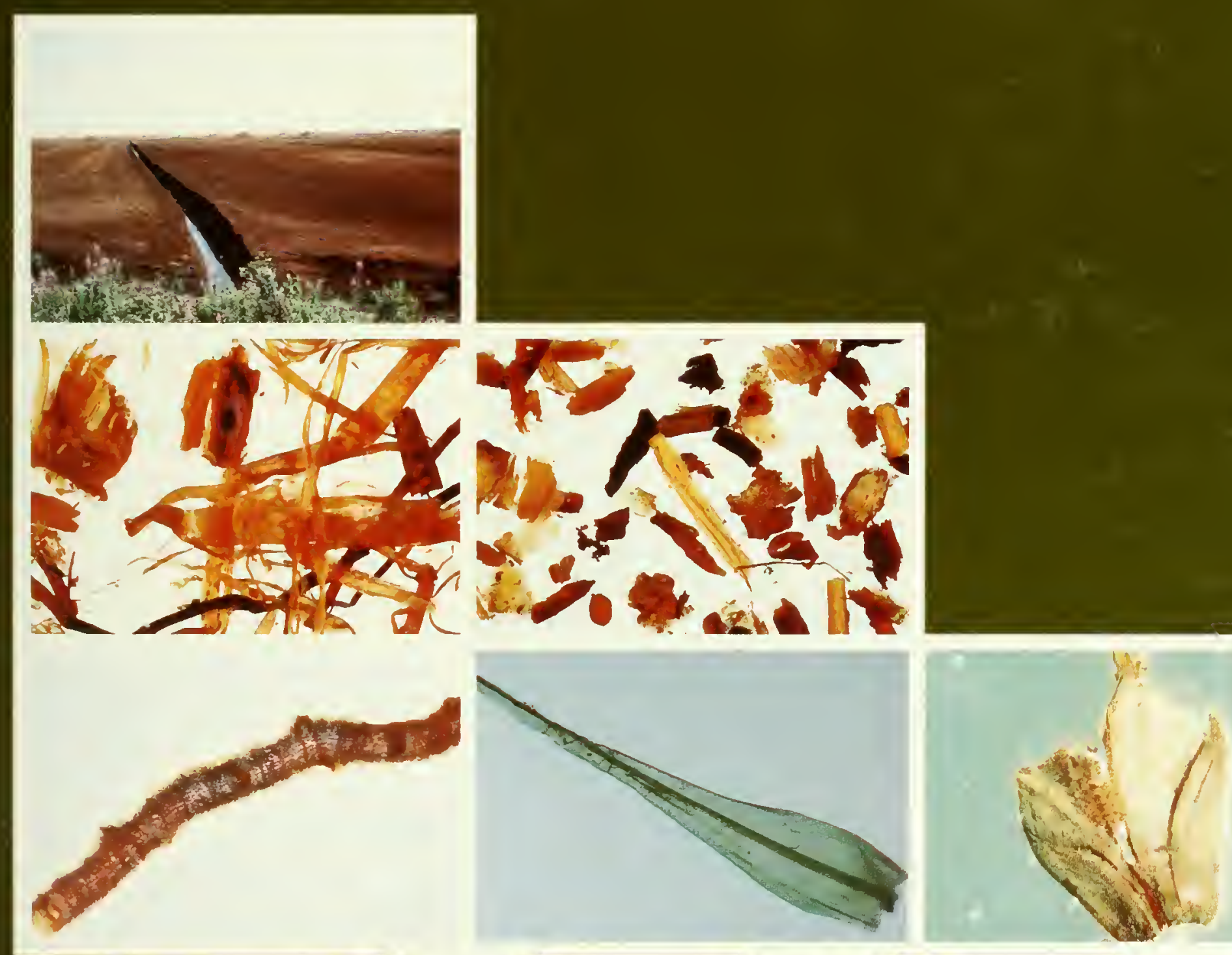
Digitized by the Internet Archive in 2011 with funding from

Agriculture and Agri-Food Canada - Agriculture et Agroalimentaire Canada 


\section{Guide to the identification of plant macrofossils in Canadian peatlands}

P.F.M. Lévesque

$\mathrm{H}$. Dinel

A. Larouche 1

Land Resource Research Centre Ottawa, Ontario

Research Branch Agriculture Canada

Publication No. 1817 

- Minister of Supply and Services Canada 1988
Available in Canada through
Authorized Bookstore Agents and other bookstores
or by mail from
Canadian Government Publishing Centre
Supply and Services Canada
Ottawa, Canada K1A 0S9

\section{Catalogue No. A 15-1817/1988E}

ISBN 0-660-92289-4

Price subject to change without notice.

\section{Canadian Cataloguing in Publication Data}

Lévesque, P. E. M.

Guide to the identification of plant macrofossils in Canadian peatlands

(Publication : 1817E)

Issued also in French under title: Guide illustre des macrofossiles veretaux des tourbières du Canada.

1. Bryoplaytes, Fossil--Identification.

2. Paleobotany-Canada. 3. Peatlands-Canada.

I. Dinel. H1 Henri, 1950 H. Larouche. A.

III. Title. IV. Series: Publication ICanadia

Agriculture Canada). English: 1817E.

QE959.1.4 $1987 \quad 561 ' .80971 \quad$ C870992058 


\section{CON'TEN'TS}

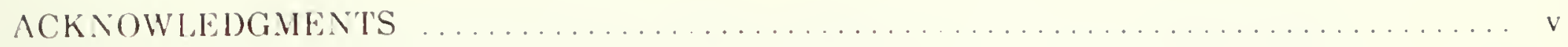

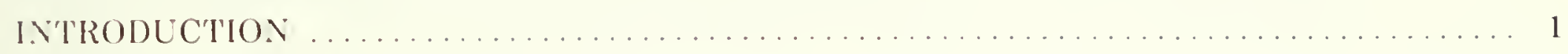

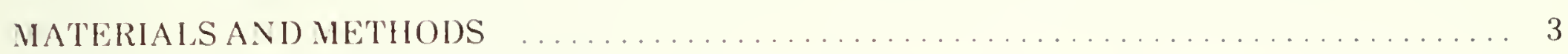

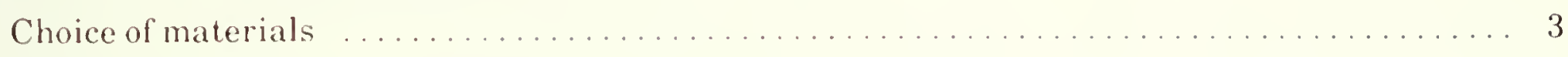

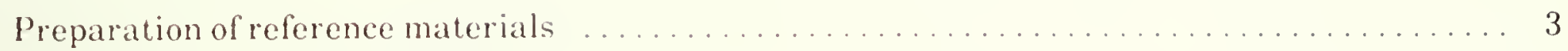

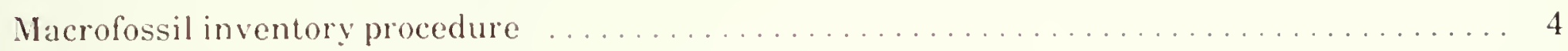

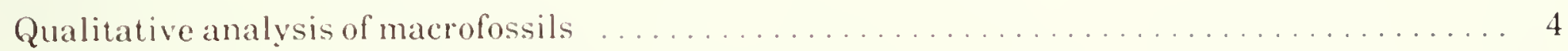

Quantitative analysis of macrofossils and definition of assemblages . . . . . . . . . . 4

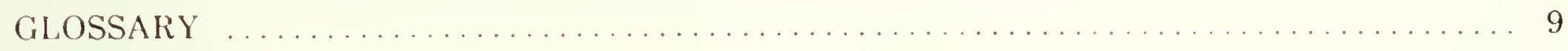

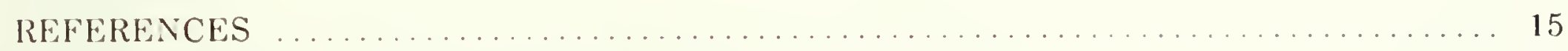

IDENTIFICATION KEYS TO PLANT MACROFOSSILSIN PEATS . . . . . . . . .. 17

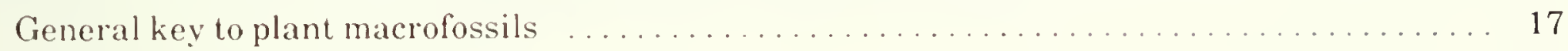

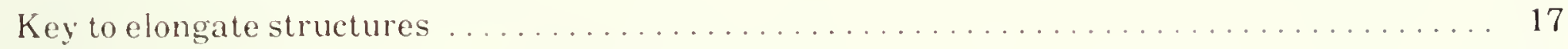

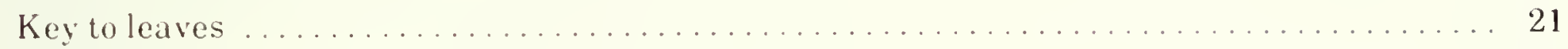

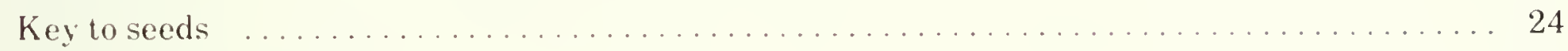

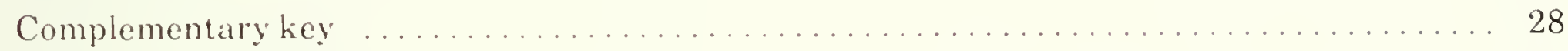

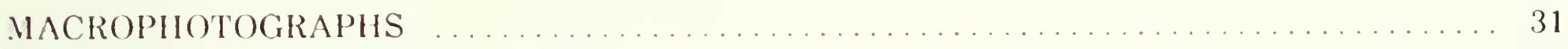

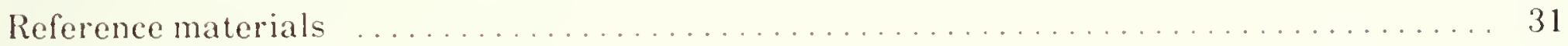

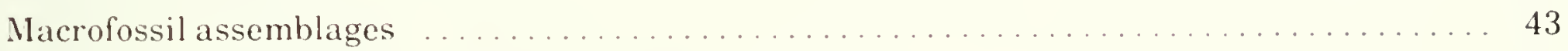

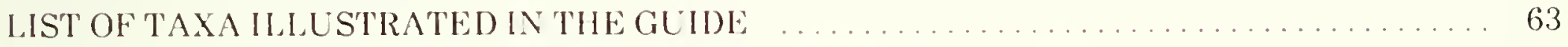





\section{ACKNOWLEDGMENTS}

The authors acknowledge Dr. M-A. Geurts of University of Ottawa and Dr. P. Comtois of University of Montreal for their helpful comments and suggestions, and Dr. P.J.H. Richard of University of Montreal for his support and encouragement. 

In 1974, when the land Resource Research Centre (Centre de recherche sur les terres) initiated its study of peats and peat soils, the level of knowledge in this field was sparse. There was no basic reference work and no identification guide to support any efforts at characterization of peat soils or to permit the identification of macrofossils or peat materia!s. Then, as now, except for the publications by GrosseBrauckmann (1972, 1974, and 1976) there was a scarcity of work devoted to the identification of plant macrofossils in peat.

The elements of the present report were compiled over the years as our own paleobotanical, ecological, and pedological research on peatlands progressed. We are pleased to share the fruits of our labors with others associated, whether closely or remotely, with peat exploitation who feel the need for reference work for use in identifying and differentiating peat materials.

The objective behind the preparation and publication of this guide was to assist prospectors, pedologists, and other potential users in identifying the plant remains and peat materials commonly encountered in Canadian peatlands. The guide lists the most representative peat materials found during the exploration of more than 50 organic deposits in Canada, particularly in eastem Canada, as well as macrofossil analyses for some 30 deposits. In order to facilitate the identification and the registration of differentiating features, the macrofossil assemblages are grouped in terms of their initial association. The elements of fresh plant materials have also been added in order to ensure an improved botanical coverage and a more precise identification of the macroremains.

The macrofossils are treated individually for identification purposes. 'They are then replaced in their respective natural assemblages in order to maintain the botanical and ecological relationships useful in the establishment of the principal types of peat and peat materials.

The photographs of the macrofossils and the reference elements, accompanied by their identification, form the essential features of the guide. The glossary ensures a better understanding of the terminology used, as well as a precise and more appropriate utilization of the descriptions and distinctive characteristics of the plant macroremains.

The identification keys are intended to facilitate the identification procedure. 'They are based on the nature and morphology of the fragments encountered and, when used in the context of our work, should prove to be very effective tools. We hope that the users of the heys will be able to contribute to their further improvement.

'l'he plants whose remains make up peat have been subjected to the effects of time and environmental factors while undergoing the process of fossilization. 'Thus, the peaty mass we see today is composed of elements that are more or less decomposed, modified, or transformed. A certain amount of segregation has taken place, and as a result, the elements encountered today represent the most resistant. The distinctive properties used to identify the plant macrofossils should, therefore, have sufficient resistance to persist for long periods of time. Although segregation of the materials introduces a slight deformation to the botanical component, this does not affect the exercise because the stated objectives are to identify and differentiate the different types of peat materials. It would be another matter if our aim was to reconstruct the "parent" vegetation and its evolution in a particular ecological context.

The level of iclentification of plant macrofossils remains dependent on the conditions imposed by the type of analysis possible in the field and on the means available to the prospector. The equipment generally used by a prospector consists of an ordinary hand lens $(4-20 \mathrm{X})$, and the work is usually done in unfavorable lighting conditions. Water-washing of the materials on a $150-\mu \mathrm{m}$ sieve results in a more revealing examination. It is still possible to confirm or reject an initial identification by conducting a laboratory verification, using a binocular microscope at higher magnification.

The guide lists 390 plant specimens, that is, 240 macrofossil elements and 150 reference elements. These elements are grouped under 22 families (40 genera), and are subdivided into the following four groups:

Lignosae - four families ( 13 genera)

Herbacae - five families (12 genera)

Muscinae - nine families (nine genera)

Pteridophytae - four families (six genera) 



\section{MA'TERIAL AND METHODS}

\section{Choice of materials}

The macrofossils inventoried or used here are linked to 15 types of assemblages. 'The understanding we have acquired concerning peat materials, their principal composition, their distribution, and their relative contribution to the overall peat mass is the result of investigations conducted on more than 50 deposits located in the temperate zone of Canada, and of macrofossil analyses of materials taken from approximately 30 of these deposits. The materials sampled, which enabled us to identify 15 typical macrofossil assemblages, were taken from seven different deposits (Table 1) and covered six different types of peat landform. 'The desire to avoid repetition of the same types of macrofossils and to keep them within their natural assemblages was the prime motive behind our choice. Due to the insights we acquired in the field, and from the investigations of other authors, the 22 families (40 genera) of plants listed in this guide are in accordance with the botanical profile of the vast majority of the peatlands of the temperate zone of Canada.

The peat material was wet-sieved in order to separate macrofossils larger than $0.450 \mathrm{~mm}$ that could be identified at a magnification of less than $20 \mathrm{X}$, according to the procedure described by Dinel and Lévesque (1976). This sieving step permitted us to remove the very fine particulates, as well as the decomposition products enerusting the surface of the macrofossils. It also enabled us to inventory the macrofossils in terms of their size, which greatly improved the quantitative information obtained

Organs of living plants were added to the macrofossil collection to expand the botanical coverage of this report. 'The additions comprise species which could be or have been found at one time or another in peat materials sampled by us.

\section{Preparation of reference materials}

The reference materials were collected during visits to various peat deposits in eastern Canada. 'The speeimens were washed in water and cleaned of all materials that might obscure the distinctive morphological elements. They were then preserved in a solution of formaldehyde, acetic acid, and ethanol (Johansen 1968). The specimens were lightly stained with a solution of methyl blue in order to give contrast to morphological elements that would otherwise have been difficult to see. The treatment with methyl blue also proved useful in the identification of certain fossilized Muscinae leaves.

Table 1. Provenance of typical macrofossil assemblages

\begin{tabular}{|c|c|c|c|c|}
\hline Typical macrofossil assemblages & Peat landform & Site & Coordinate & es \\
\hline $\begin{array}{l}\text { Lignosae-Herbacae } \\
\text { Lignosae-Ierbacae-Pteridophytae } \\
\text { Herbacae-Muscinae (SH + DP) } \\
\text { Herbacae-Lignosae (LA) }\end{array}$ & Deltaic marsh & Keswick, Ont. & $\begin{array}{l}79^{\circ} 31^{\prime} \text { long. } \\
44^{\circ} 12^{\prime} \text { 'lat. }\end{array}$ & $\begin{array}{l}W \\
N\end{array}$ \\
\hline $\begin{array}{l}\text { Herbacae-Muscinae } \\
\text { Pteridophytae-Lignosae-Herbacae }\end{array}$ & Basin swamp & Alfred, Ont. & $\begin{array}{l}74^{\circ} 49^{\prime} \text { long. } \\
45^{\circ} 28^{\prime} \text { lat. }\end{array}$ & $\begin{array}{l}\text { W } \\
\text { N }\end{array}$ \\
\hline $\begin{array}{l}\text { Herbacae-Muscinae-Lignosae } \\
\text { Muscinae-Herbacae }\end{array}$ & Basin swamp & Albion Road, Ont. & $\begin{array}{l}75^{\circ} 37^{\prime} \text { long. } \\
45^{\circ} 18^{\prime} \text { lat. }\end{array}$ & $\begin{array}{l}\text { W } \\
\text { N }\end{array}$ \\
\hline Muscinae & Dome bog & St. Charles, N.B. & $\begin{array}{l}64^{\circ} 57^{\prime} \text { long. } \\
46^{\circ} 38^{\prime} \text { lat. }\end{array}$ & $\begin{array}{l}\text { W } \\
\text { N }\end{array}$ \\
\hline $\begin{array}{l}\text { Herbacae } \\
\text { Herbacae-Lignosae }\end{array}$ & Coastal high marsh & St. Andrew, P.E.I. & $\begin{array}{l}62^{\circ} 50^{\prime} \text { long. } \\
46^{\circ} 22^{\prime} \text { lat. }\end{array}$ & $\begin{array}{l}\text { W } \\
\text { N }\end{array}$ \\
\hline $\begin{array}{l}\text { Lignosae-Herbacae-Muscinae } \\
\text { Lignosəe-Muscinae-Herbacae }\end{array}$ & Basin bog & Gable Head, P.E.I. & $\begin{array}{l}63^{\circ} 33^{\prime} \text { long. } \\
46^{\circ} 26^{\prime} \text { lat. }\end{array}$ & $\begin{array}{l}\text { W } \\
\text { N }\end{array}$ \\
\hline $\begin{array}{l}\text { Muscinae-Lignosae } \\
\text { Muscinae-Herbacae-Lignosae }\end{array}$ & Raised bog & Black Banks, P.E.I. & $\begin{array}{l}64^{\circ} 00^{\prime} \text { long. } \\
46^{\circ} 44^{\prime} \text { lat. }\end{array}$ & $\begin{array}{l}\text { W } \\
\text { N }\end{array}$ \\
\hline
\end{tabular}


Macrofossil inventory procedure

The methodology used in the inventory of the macrofossils may be divided in to two steps. First, the botanical identification of the fragment was made, followed by the quantitative evaluation of the different botanical components that defined the macrofossil assemblage. In our study, however, identification and the quantitative evaluation were done at the same time.

\section{Qualitative analysis of macrofossils}

The foregoing system enabled us to identify macrofossils specimen by specimen. It also made it possible to take into account the origin and the botanical nature of the macroremains as well as the degree of expertise of the analyst. All the macroremains inventoried are identified by an alphabetic code composed of two letters to indicate the origin and the hotanical nature of each fossil; the code is used to identify the botanical components (B.C.) during the counting (Fig. 1). Lists I, II, III, and IV were established for this purpose. They are not exhaustive, and their contents can be shortened, added to, or adjusted, according to usage.

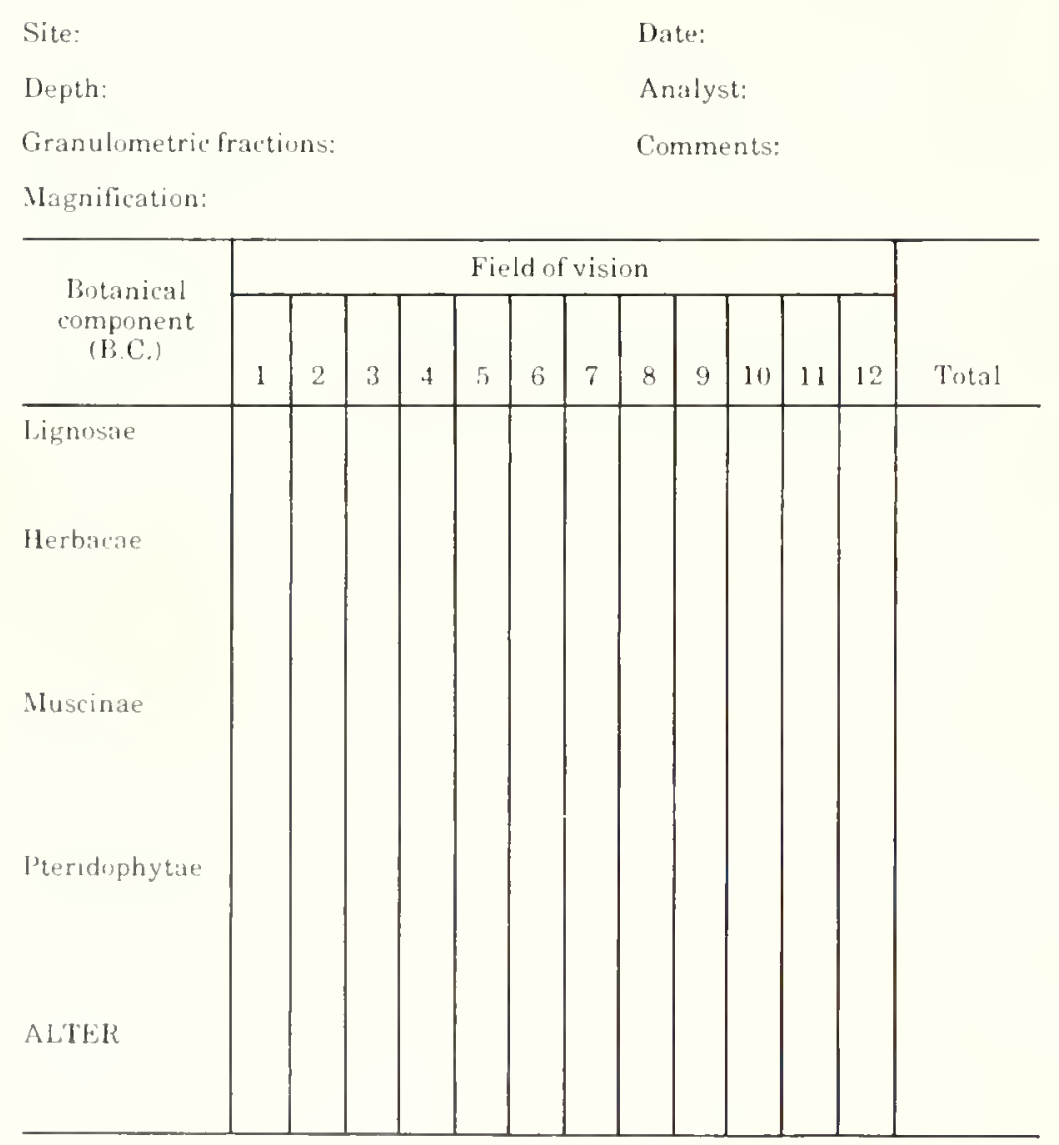

Fig. 1. Tally sheet

The four levels of differentiation used in this system (Table 2) have the advantage of providing an identification of the macrofossils. In this way, the first level, being of an inclusive nature, allows the identification of a macrofossil as belonging to the Lignosae, Herbacae, Muscinae, or Pteridophytae group. The other levels of differentiation, however, assign to a macrolossil an identification that is progressively more refined and exclusive, and they demand a higher degree of expertise regarding the organs and tissues of peatland plants.

Table 2. Levels of differentiation of the botanical origin of macrofossils

Level 1 luevel 2 Level 3 Level 4

\section{Groups}

Lignosae (LI)

Families Genera Species

Herbacae (HE)

Pteridophytae ( $\mathrm{PT})$

Muscinae (MU)

ALTER $\left(\mathrm{AL}_{4}\right)$

This way of differentiating the botanical origin of the plant macrofossils and the macrofossil assemblages has led to the creation of several terms that allow the systematic grouping of certain families within the context of contemporary plants. The first level of differentiation is divided into four groups (Lignosae, Ilerbacae, Pteridophytae, and Muscinae) that correspond to the dominant plant groups encountered in the various peat materials. Next, the assignment is progressively made to families, then to genera, and then to species. As a result of this process, the Lignosae group contains all the arborescent and shrubby vegetation: the llerbacae group encompasses all the herbaceous families (Cyperaceae, Gramineae, Joncaceae): the Pteridophytae group is used in instances where the macrofossils to be identified may belong to the Equisetaceae, the Osmondaceae, or the Polypodiaceae; and the Muscinae group is used for macrofossils that may belong to all the vegetal families contained in the Bryophyta division.

Quantitative analysis of macrofossils and definition of assemblages

The counting of a minimum of 500 macrofossils is done on each of the three granulometric fractions retained after the wet-sieving of $30 \mathrm{~g}$ of peat material. The counting of all the material in these fractions is virtually impossible, so a subsample is taken containing a minimum of 500 specimen fragments, which are then spread out on a microscopic slide provided with a grid. Particular attention is given to the proper spreading of the specimens on the slide in order to avoid overlapping. Each of the fields of vision were counted, using a binocular microscope, until the minimum number of individual specimens is 
obtained. In general, 10 or 12 fields of vision are necessary in order to obtain a count of 500 specimens (Dinel et al. 1983).

After the counting of each of the three granulometric fractions is completed, this information is grouped in a summary data sheet (Fig. 2), which allows us to define the macrofossil assemblage being studied. According to the objectives of the study, it is possible to obtain more or less detailed information on the origin and botanical nature of the macrofossils, and on the relative frequency of occurrence of each of these fossils, in accordance with the degree of expertise of the analyst.

This method is very effective for differentiating peat materials in terms of their botanical origin while keeping the dimensions of the macrofossil in mind. In practice, the analyst would have a tendency to overestimate the importance of the larger specimens at the expense of the smaller ones. However, in paleoecological studies, this method allows us to collect more information on the total population of macrofossils, and makes it possible to obtain an improved interpretation (Dinel 1984).

List I. List of organs, tissues, and their codes

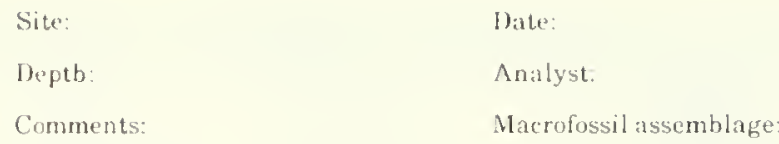

Site: Date:

Deptb:

Analyst:

Comments:

Macrofossil assemblage

Magnification:

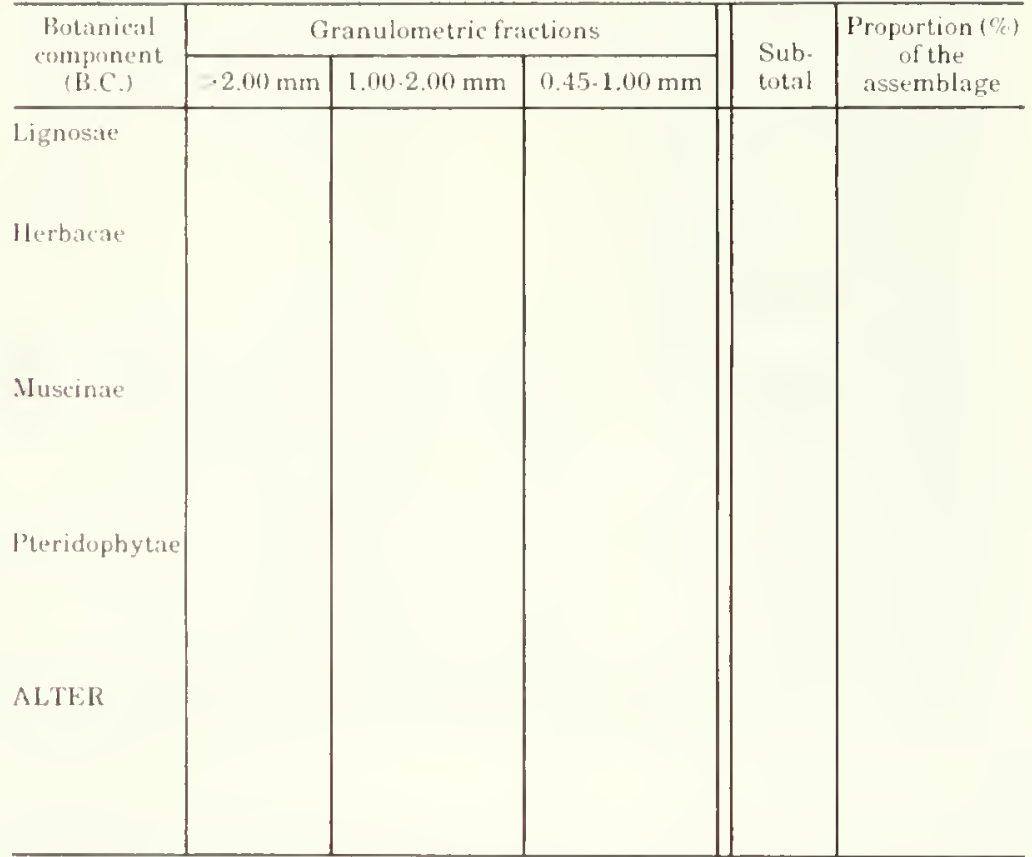

Fig. 2. Summary sheet

English

French

latin

Code

branch

branchlet

bract

bud

bud scale

capsule

collenchyma

cone scale

cortex

crown

epidermis

fruit

leaf

leafy stem

mesoblast

needle

node

residual tissues

rhizome

rhizome scale

root

runner

sclerenchyma

seed

sporangium

stem

strobile

vascular bundle

xylem

branche
rameau
bractée
bourgeon
écaille de bourgeon
capsule
collenchyme
écaille de cones
écorce
collet
épiderme
fruit
feuille
tige feuillée
mésoblaste
aiguille
noeud
reste tissulaire
rhizome
écaille de rhizome
racine
stolon
sclérenchyme
graine
sporange
tige
strobile
nervure
xylème

ramus
ramellus
-
gemma
-
-
collenchyma
-
cortex
-
liber
fructus
folium
stipes-folium
-
acus
nodus
-
rhiza
radix
-
sclerenchyma
granum
sporangium
stripes
strobilus
nervus
-

$\mathrm{Rm}$

Re

$\mathrm{Br}$

Ge

Eb

$\mathrm{Ca}$

$\mathrm{Cl}$

Ec

Co

Cf

$\mathrm{Li}$

$\mathrm{Fr}$

$F_{0}$

Sf

Me

Ac

No

$\mathrm{Rt}$

Rh

Er

Ra

$\mathrm{Sn}$

$\mathrm{Sc}$

Gr

Sp

St

$\mathrm{Sr}$

$\mathrm{Ne}$

$\mathrm{Xy}$ 
List II. List of families and their codes

\begin{tabular}{llll}
\hline Aceraceae & AC & Grimmiaceae & GI \\
Amblystegiaceae & AM & Gramineae & GR \\
Aquifoliaceae & AQ & Hypnaceae & HY \\
Araliaceae & AR & Jypericaceae & HE \\
Aulaconniaceae & AU & Joncaginaceae & JO \\
Betulaceae & BE & Labiateae & LB \\
Brachytheciaceae & BR & Iycopodiaceae & LY \\
Bryaceae & BY & Myricaceae & MY \\
Capriofoliaceae & OA & Osmondaceae & PS \\
Climaciaceae & CL & Polypodiaceae & PI \\
* Conifer & CO & Polytrichaceae & PO \\
Cupressaceae & CU & Primulaceac & PL \\
Cyperaceae & CY & Salicaceae & PM \\
Dicranaceae & DI & Selaginellaceae & SA \\
Empetraceae & EM & Sphagnaceae & SE \\
Equisetaceae & EQ & Umbelliferaceae & SH \\
Ericaceae & ER & & UM \\
Gentianaceae & GN & & \\
\hline
\end{tabular}

* Other tasonomic unit

List III. List of genera and their codes

\begin{tabular}{|c|c|c|c|}
\hline Abies & $A B$ & Lycopus & LO \\
\hline Acer & $\mathrm{AC}$ & Lysimachia & $\mathrm{L} S \mathrm{~S}$ \\
\hline Alnus & $\mathrm{AL}$ & Menyanthes & ME \\
\hline Amblystegium & AY & Myrica & MR \\
\hline Andromeda & $\mathrm{AN}$ & Mnium & $\mathrm{MN}$ \\
\hline Aralia & AA & Nemopanthus & $\mathrm{NE}$ \\
\hline Aronia & $\mathrm{AR}$ & Onoclea & $O N$ \\
\hline Aulacomnium & $\mathrm{AO}$ & Osmunda & $\mathrm{OM}$ \\
\hline Betula & BT & Phragmites & PH \\
\hline Calamagrostis & $\mathrm{CM}$ & Picea & PE \\
\hline Calliergon & $\mathrm{CG}$ & Pinus & PN \\
\hline Carex & $\mathrm{CR}$ & Pleurozium & PR \\
\hline Chamaedaphne & $\mathrm{CS}$ & Pohlia & PB \\
\hline Cladium & CD & Populus & PP \\
\hline Climacium & $\mathrm{Cl}$ & Potentilla & PJ \\
\hline Dicranum & DC & Polypodium & PY \\
\hline Drepanocladus & DP & Polytrichum & $\mathrm{PC}$ \\
\hline Dryopteris & DR & Pteridium & PT \\
\hline Dulichium & $\mathrm{DU}$ & Ptilium & $\mathrm{PU}$ \\
\hline Elocharis & EL & Rhacomitrium & $\mathrm{RO}$ \\
\hline Empetrum & EP & Rhododendron & $\mathrm{RH}$ \\
\hline Equisetum & $\mathrm{EV}$ & Rhynchospora & $\mathrm{RY}$ \\
\hline Eriophorum & EI & Salix & SL \\
\hline Gaylussacia & GA & Scheuchzeria & $\mathrm{SZ}$ \\
\hline Glyceria & GL & Scirpus & $\mathrm{SC}$ \\
\hline Hylocomium & HIL & Spartina & $\mathrm{SP}$ \\
\hline Hypericum & $\mathrm{HA}$ & Sphagnum & SH \\
\hline IIурпит & HP & Thuja & TH \\
\hline Juncus & $J U$ & Triglochin & $\mathrm{TR}$ \\
\hline Kalmia & $\mathrm{KA}$ & Typha & TP \\
\hline Larix & LA & Vaccinium & VA \\
\hline Ledum & LE & Viburnum & VI \\
\hline Lycopodium & LC & Viola & $\mathrm{VO}$ \\
\hline
\end{tabular}


List IV. List of secondary components (ALTER)

Acarians

ACAR

Aggregate of fine roots of Herbacae

AGHE

Aggregate of fine materials

AGAM

Calcarius (calcareous)

CALC

Cenococcum

CENO

Charcoal

ClIAR

l'aecis (fecal pellets)

FEPE

Gastropoda (one valve)

GAST

llelicoids

HELI

Mveorhizae

MUCO

Mycorhizae ectotrophic

MYEC 



\section{GLOSSARY}

aculeate

Having very small prickles.

\section{acuminate}

Tapering to the apex; sides more or less pinched in before the tip.

\section{alar cell}

Differentiated cell at the base of the leaf.

\section{alveolate}

Having the appearance of a honeycomb.

\section{anasomosis}

Ornamentation on the surface of the bark or the tegument of seeds, composed of elongate rope-like ridges, many of which cross or touch one another (e.g., the bark surface of

Chamaedaphne calyculata older than 2 years).

\section{areolate}

Having small spaces between the leaf veins.

\section{asymmetric}

Not symmetrical.

\section{barbellate}

Having short, stiff, hooked hairs or bristles.

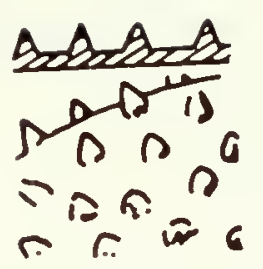

\section{canescent}

llaving a fine, grayish white

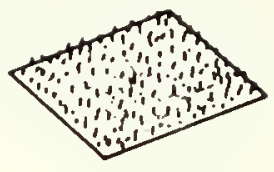
pubescence.

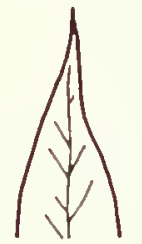

\section{carenate}

Longitudinal protrusion, or keel, along the back of an organ (e.g., a leaf).

\section{collenchyma ( $p l$ collenchymata)}

A support tissue composed of living cells more or less elongate, equipped with an irregularly lignified primary wall (Pl. 31-9).

colliculate

Having small elevations.

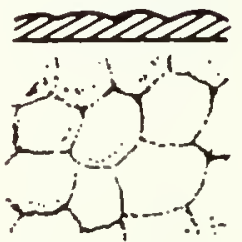

\section{conduplicate}

The $V$-shaped cross section common to certain linear leaves (needles), e.g., the leaf of Juniper communis.

\section{cordate}

Heart-shaped.

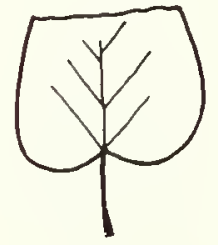

\section{costa (pl. costae)}

Leaf vascular bundle associated with the Muscinae.

\section{cucullate}

Hood-shaped; having basal edges rolled inward.

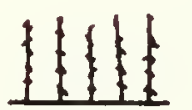

\section{(1)}


cuneate

Varrowly triangular with acute angle toward base: wedge-shaped.

cuspidate

Abrupt, short, sharp, firm point at the apex.

\section{cymbifoliate}

IIaving the form of a gondola or boat.

\section{deltoid}

Triangular.

\section{dentate}

Toothed, directed outward.

\section{elliptic}

Shaped like an ellipse; widest in centre and two ends equal.

\section{emarginate}

Having a shallow marginal notch.

\section{entire}

Having the margin continuous, or not divided by teeth or serrations.
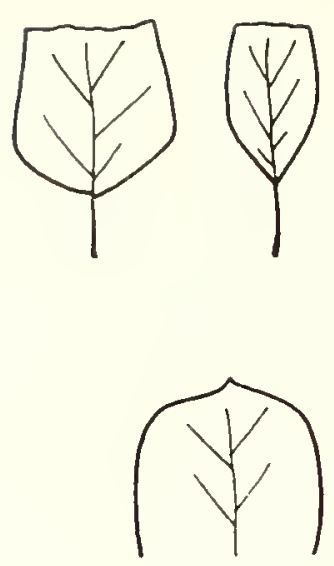

\section{falcate}

Scythe- or sickle-shaped.
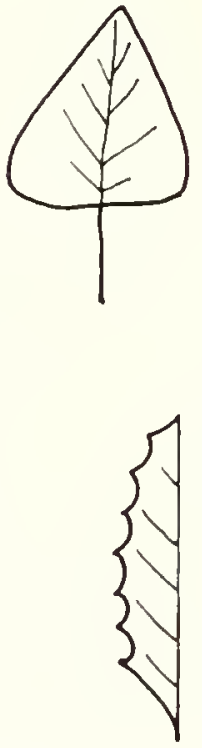

foveate

Pitted.

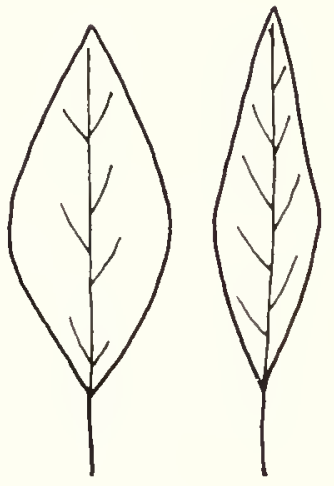

\section{glochicliate}

Having barbed tips.

granulate

Granulated

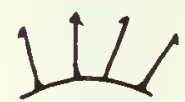

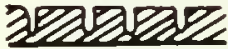

- 000

0000

$\circ 000$

0.000

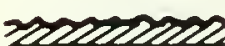

$000 \% 00 \mathrm{\circ}$ $\because 000 \%$

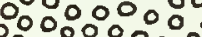

0.000000

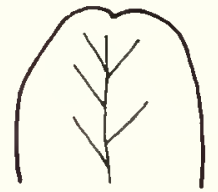

hilum

Scar left on the tegument of the seed after the detachment of the funiculus.

\section{hirsute}

Having moderately coarse,

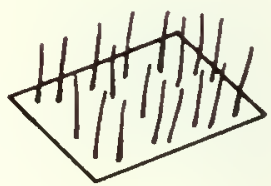
stiff hairs. 


\section{hydathode}

Structure, modified from leaf conductive tissue, that allows the exudation of water through a pore (Scheuchzeria palustris) (Pl.9-9).

\section{hydrocyte}

A cell that covers the stem of Sphagnum sp., and which permits the retention of a large amount of water (Pl.31-1).

\section{insect elytra}

Chitinous, leathery outer wing parts that cover and protect the flight wings of Coleoptera (beetles) (Pls. 14-10 and 17-9).

\section{lanceolate}

Tapering to a point at apex: several times longer than wide.

\section{linear}

Leaf narrow and flat with sides parallel.

\section{lineate}

Marked with lines or stripes.

\section{lineolate}

Marked with fine lines.

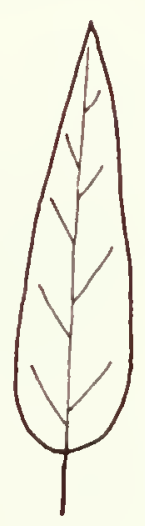

\section{obovate}

More or less ovate with basal end narrower.

\section{obtuse}

Blunt at the apex.

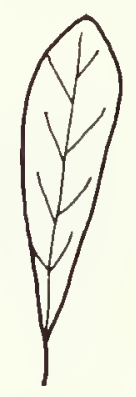

\section{oogonium (pl. oogoniums)}

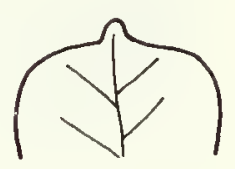

mycorrhiza (pl. mycorrhizae)

Fungi living in association with roots of certain plant species.

Organ where the female cells are formed in the Thallophytes (Pl.31-4), e.g., Characeae.

\section{operculum (pl, opercula)}

Lid covering the mouth of a moss capsule.

oval

Broadly elliptic.

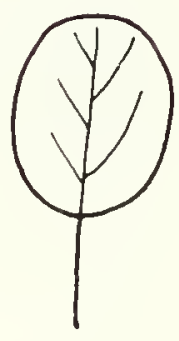

\section{ovate}

Having an outline similar to longitudinal section of an egg; oval-shaped.

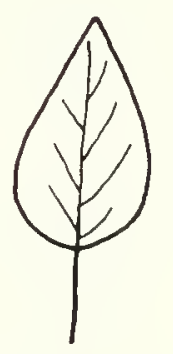


Haring the stem or support at tached to the lower surface instead of at the margin or base: umbrellalike.

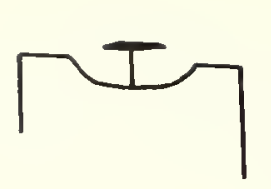

perigynium (pl. perigynia)

Fruit envelope of the Carex group (PI.19-9).

pubescent

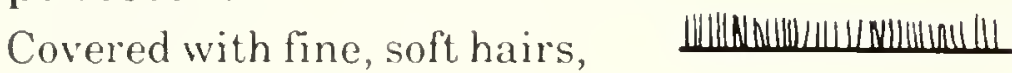
or downy.

\section{punctate}

Dotted with depressions or minute spots.

\section{pustulate}

Covered with pustules; pimple-like elevated area covering surface tissues.

\section{rachis}

Part of a plant bearing the folicles (leaflets) in the fern group (Pls.31-1 and 30-3).

\section{ramate}

Related to branch leaf.

\section{reticulate}

Having veins or lines that form a network.

retuse

Having the apex rounded or obtuse with a slight notch.

revolute

Property of leaves whereby the edges are partially curled downward, e.g., leaf of Ledum groenlandicum.

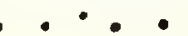

$\therefore \because \therefore$
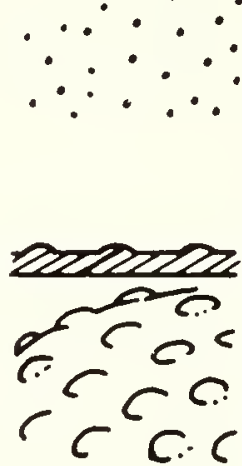

\section{ribbed}

Having marks like a rib; ridged.

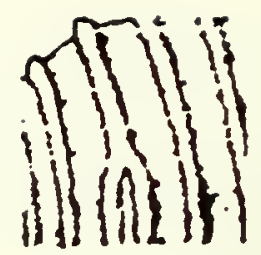

rounded-obtuse

Circular; not pointed or acute.

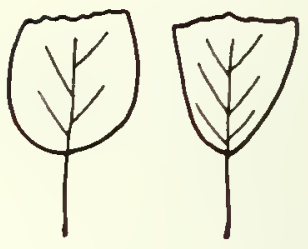

\section{rugose}

Wrinkled.

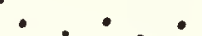

\section{scabrous}

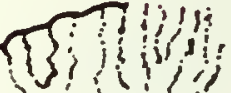

in

)

If mili

Rough to the touch; prickly.

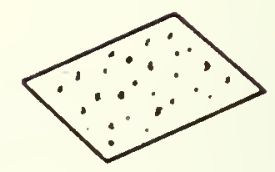

\section{scalariform}

IIaving transverse bars.

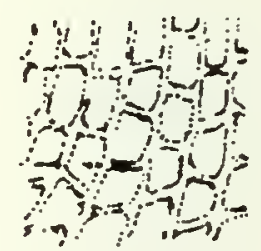

sclerotium (pl. sclerotia)

Asexual mass of fungal mycelia.

\section{scrobiculate}

Having numerous shallow grooves.

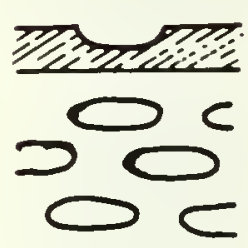

\section{semicircular}

Half-mooned outline of the transverse cross section of leaves, e.g., leaf of Pinus banksiana.

\section{serrate}

Saw-toothed, directed forward. 
spatulate

Broad and rounded at apex

and tapering at base: shaped

like a flattened spoon.

sporangium (pl. sporangia)

Spore sac of a capsule.

\section{statoblast}

Discoid capsule covered by a chitinous membrane, used for asexual reproduction in bryozoans (P1.31-7).

\section{stipitate}

Ilaving or borne on a support, or short stalk.

\section{striate}

Marked with parallel lines.

style

Upper elongation of the ovary within which the pollenic tube develops.

\section{sulcate}

Furrowed, or grooved.

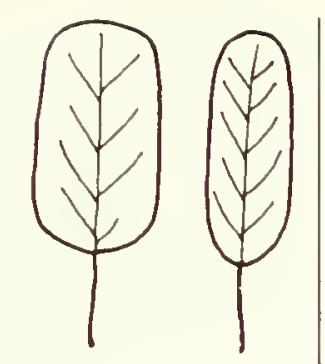

\section{tegument}

Seed case, or envelope.

tomentose

Covered with densely matted hairs.

\section{truncate}

Base or apex transversely straight or nearly so, as if cut.

\section{tuberculate}

Having small nodules.

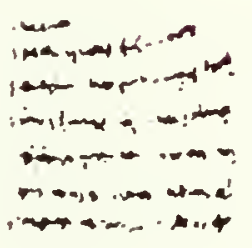

uncinate

Bent at the apex like a hook.

\section{undulate}

Having a wavy surface.

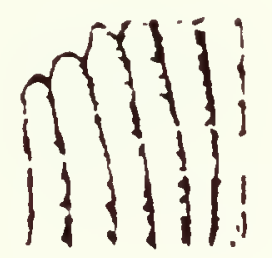

\section{verrucose}

Warty.

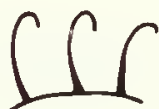

8

लำt"

ति $60^{6}$

$\therefore \approx C^{\circ}$

40

if

ग1:

?
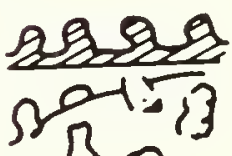

5000 



\section{REFERENCES}

Berggren, C. 1969. Atlas of seeds. Part 2: Cyperaceate. Swed. Nat. Sci. Res. Counc. Stockholm. 68 p.

Conrad, H.S.; Redfearn, P.L. 1979. How to know the mosses and liverworts. Dubuque, Ia.: Wm. C. Brown Co. 320 p.

Crum, H. 1976. Mosses of the Great Lake region. Michigan: University herbarium, Univ. Michigan. $404 \mathrm{p}$.

Crum, H.A.; Anderson, L.E. 1981. Mosses of eastern North America. New York: Columbia Univ. Press. Vols. 1-2.576 p.

Dinel, H. 1984. Aspects paléo-écologiques et pédologiques du marais tourbeux de Keswick, Ontario. Montreal, P.Q.: Univ. Montreal. Thesis. $218 \mathrm{p}$.

Dinel, H.; Larouche A.; Lévesque, M. 1983 Evaluation de deux méthodes de quantification des macrofossiles dans les matériaux tourbeux. Nat. Can. 110:429-434.

Dinel, H.; Lévesque, .M. 1976. Lne technique simple pour l'analyse granulométrique de la tourbe en milieu aqueux. Can. J. Soil Sci. $56: 119-120$.

Fernald, M.L. 1950. Gray's Manual of botany 5 th ed. New York: American Book Co. 1632 p.

Gleason, H. 1952. The new Britton and Brown illustrated flora of the northeastern United States and adjacent Canada. New York: N.Y Bot. Gard. 3 vol.

Grosse-Brauckmann, G. 1972. Uber pflanzliche Makrofossilien mitteleuropaischer 'Torfe. 1. Gewebereste Krautiger Pflanzen und ihre Merkmale. Telma 2:19-55.

Grosse-Brauckmann, G. 1974. Uber pflanzliche Makrofossilien mitteleuropaïscher Torfe. 2. Weitere Reste (Früchte und Samen, Moose u.a.) und ihre Bestimmungsmoglichkeiten. Telma 4:51-117.

Grosse-Brauckmann, G. 1976. Ablagerungen der Moore. Pages 91-133 in K H Göttlich, ed. Moore - und Torfkunde Stuttgart.

Grout, A.J. 1903. Mosses with hand-lens and microscope. Ashton, Md: Eric Lundberg. $416 \mathrm{p}$.

Harrington, H.D.; Durrell, L.W. 1957. How to identify plants. Chicago, Ill: The Swallow Press Inc. 203 p.

Johansen, D.A. 1968. Plant microtechnique. New York: McGraw-Hill Book Co. 523 p.
Katz, N.J.; Katz, S.W.; Kipiani, M.G. 1965. Atlas and keys of fruits and seeds occurring in the quaternary deposits of the USSR. Moscow. $366 \mathrm{p}$.

Lalrouche, A. 1979. Iistoire post-glaciaire comparée de la végétation à Sainte-Foy et au Mont des Éboulements, Québec, par l'analyse macrofossile et l'analyse pollinique. Sainte-Foy, P.Q.: Univ. Laval. These. 117 p.

Iévesque, M. 1981. Characterization and differentiation of peat materials in the context of peat soils classification. Proceedings of the organic soils mapping and interpretation workshop. Fredericton, N.13.: Agriculture Canada. pp. 76-104

Lévesque, M.; I)inel, H. 1977. Fiber content, particle-size distribution and some related properties of four peat materials in eastern Canada. Can. J. Soil Sci 57:187-195.

Lévesque, M.; Dinel, H. 1982. Sone morphological and chemical aspects of peats applied to the characterization of Histosols. Soil Sci. 133:324-332.

Lévesque, M.; Dinel, H.; Marcoux, R. 1980. Evaluation des critères de différenciation pour la classification de 92 matérialux tourbeux du Québec et de l'Ontario Cann. J Soil Sci. 60:479-486.

I.évesque, M.; Millette, J.A. 1977. Description morphologique et aspects chimiques de la tourbière à laîches de Farnham, Québec. Nat. Can. 104:511-526.

Lévesque, M.; Morita, H.; Schnitzer, M.; Mathur, S.P. 1980. The physical, chemical and morphological features of some Quebec and Ontario peats. Agriculture Canada. LRRI Contrib. 62. 70 p.

Marie-Victorin (Frère E.C.) 1964. Flore Laurentienne. Montreal, P.Q.: Univ. Montreal. Press. 925 p.

Murley, M.M. 1951. Seeds of the Cruciferae of north eastern America. Am. Midl. Nat. $46(1): 1-81$

Nilsson, T. 1968. Notes de cours de paléoécologie; Textes et illustrations (suédois). Sweden: Univ. Lunds. 63 plates, 238 p

Watts, W.A.: Winter, T.C. 1966 Plant macrofossils from Kirchner Marsh, Minnesota; A paleoecological study. Geol. Soc. Am. Bull. 77·1339-1360 

T'he following identification keys have been developed on the basis of the morphology and nature of specimens encountered in the various peatlands studied. More than 100 taxa divided among 26 specimen ty pes have been listed

The purpose of the keys is to describe briefly the botanical nature and origin of a specimen. Starting from a general key, the user can determine the specific key corresponding to the organic nature of the specimen to be identified. Afterward, within each key, it is then possible to establish a code composed of numbers which refer to the persistent descriptive elements of the macrofossil. Under this code, additional morphological elements can be found.

To identify a given specimen the following steps should be taken:

1. Using the general key, establish the speeific key corresponding to the nature of the specimen.

2. Determine the code corresponding to the persistent morphological elements (classification criteria) appearing in the specific key.

3. Using the code obtained, refer to the key specific to the code obtained in (2) and follow the key indicators to determine the origin of the specimen.

4. Compare the morphological elements of the specimen to those of the key, making use of the macrophotographs.

5. When the foregoing steps are completed, it is possible that the identification obtained might not be satisfactory or that the user might come to an impasse. It will then be necessary to verify the choice of classification criteria (how the code was obtained). If the same result is obtained a second time, it could indicate that the specimen falls outside our classification criteria.

The following is an example of the steps to follow in identifying a specimen. We wish to identify a specimen that has the following morphological properties: elongate, opaque, original form, dull, cylindrical, and nodulose (Pl. 27-3):

1. General key: Go to (1) because specimen is cylindrical, subelongate; surface is glossy or dull; and nodes are present.

2. Specific key: Obtain a code composed of three numbers.

First number: Tissue type $=2$ for ligneous Second number: Node type $=2$ for dot-like Third number: Surface type $=2$ for dull

The code is therefore 222 .

3. In the specific key 1.0 , go to 222 ; examine the following additional morphological properties: foliar scar, tri-verticillate, and longitudinal groove below the foliar scar.

Our specimen is therefore most likely a stem of Kalmia angustifolia (StKA an ).

1. General key to plant macrofossils

1. Specimen cylindrical, subelongate, having no bilateral symmetry, and more or less truncated at extremities; surface glossy to dull. Specimens subcircular, with loose tissues, and having one or more nodes. Stems and branches exhibiting foliar nodes or scars. (If they do not, go to 4.) Structure with leaves. (Go to 2.) (Structure includes stems, branches, roots, rachis, and rhizomes.)

\section{Key to elongate structures (p. 17)}

2. Specimen flattened, often translucent, having several or no vascular bundles. (If specimen shows bilateral symmetry, it is a leaf; otherwise it is a piece of thin bark.) This definition includes leaves assoclated or not associated with branches and thin barks.

Key to leaves (p.21)

3. Specimen with outline more or less spherical to cylindrical; surface glossy to dull; usually having bilateral symmetry whose plane passes through the major axis. Length less than $15 \mathrm{~mm}$ (includes seeds, terminal buds of mosses, and unopened cones of conifers.)

Key to seeds (p.24)

4. Specimens having other shapes. (These include wood, bud seales, opaque bark, ephippia, epiderma, fruits, hydathodes, mesoblasts, root nodules, oogoniums, opercula, sporangia, and statoblasts.)

Complementary key (p.28)

1. Key to elongate structures

This key was developed according to the type of tissue, node, and surface of the specimen.

1.1 Definition of classification criteria

\subsubsection{Tissue type}

(1) Herbaceous: Soft tissue, includes herbaceous plants and mosses, generally flattened in the peat matrix; dark stems of Sphagnum sp. fall into this category; for example, fossil stems of Typhasp.

(2) Ligneous: Rigid tissue, generally covered with bark, and retaining its original form in the peat matrix; for example, branchlets of Picea sp.

\subsubsection{Node type}

The definition of node here corresponds to all external structures that give rise to a branch or root. According to the particular specimen, the node can take several forms: 
(1) Annular-circular: Node corresponds to a ring-like feature, more or less broad, circling the clongate structure; for example, rhizome of Menyanthes trifoliata.

(2) Dot-like: Node corresponds to an external mark: aerial buds and foliar scars; for example, branches of Ledum groenlandicum.

(3) Absent: Without node.

\subsubsection{Surface type}

Surface type refers to the surficial character of the specimen.

(1) Glossy: There is no surfice sculpture and light is reflected by the surface, for example epidermis of the stem of the Cyperaceae.
(2) Dull: The rugose surface prevents the reflection of light, for example stem of Kalmia sp.

(3) Verrucose-tuberculate: Surface projections of more or less high relief are visible to the naked eye or by using a hand lens. The projections of the nodes, if they are sufficiently closely spaced, result in a tuberculate surface, for example branchlets of Picea sp.

(4) Striate-anastomotic: Small-scale tissue strands cover the surface. These might anastomose one another, for example stem of Chamaedaphne calyculata older than 2 years.

(5) Other.

1.2 Key to specific identification of elongate structures

111

(a) Structure pale whitish beige. Internodal length rather constant (approximately $2 \mathrm{~cm}$ ); root insertion points few, adjacent to nodes, and all on the same side. Remains of sheath-forming leaves over the nodes present ........... .................................. 3chehzeria palustris (Pls. 32-3, 71)

(aa) Rhizomes of other types $\ldots \ldots \ldots \ldots \ldots \ldots \ldots \ldots$ Cyperaceae

112

(a) Diameter, approximately $1 \mathrm{~cm}$; internodal length $1-4 \mathrm{~cm}$; root insertion points scattered over internodal space. Nodes continuous, annular, thin, and welldelineated. Internodal surface generally dull ................... .................................. 8)

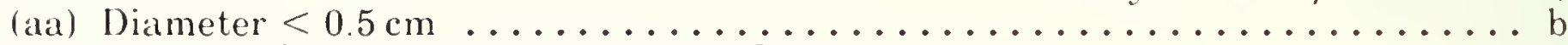

(b) Absence of roots in internodal space. Stem pale or dark ..............

(bb) Presence of at least one root insertion point $\ldots \ldots \ldots \ldots \ldots \ldots \ldots \ldots$

(c) Stem dark. Insertion points corresponding to base of leaves. Stem partially scaly

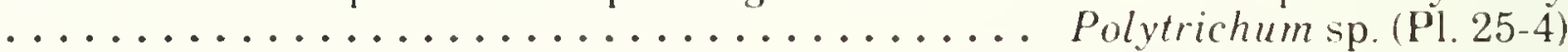

(cc) Stem pale. Node forming a thick and swollen ring. Surface distinctly striate (collenchyma fibers) $\ldots \ldots \ldots \ldots \ldots \ldots$ Calamagrostis canadensis

(ccc) Internodal surface nonstriated. Node clearly delineated and narrow ..........

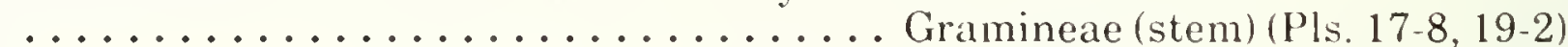

(d) Rhizome short, up to $4 \mathrm{~cm}$. Presence of dot-like and annular nodes, closely spaced

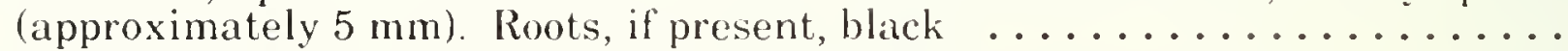
........................ Eriophorum spissum (Pls. 8-7, 23-2)

(dd) Rhizome small (diameter 3-5 mm), short or long; internodal spacing small $(<1 \mathrm{~cm}$ ). Nodes well-defined. Absence of lignified strand-like tissues. If one or more of these characteristics do not apply to the specimen, record "Rhizome of the Herbacae"; if not ............. Cypercaceae (Pls. 18-10,18-11,21-6)

122

(a) Structure pale, beige. Roots of the order $N+1$ grouped and perpendicular to the roots of the order $\mathrm{N}$ (rhizome) .............. Typha sp. (Pls. 9-5, 8-1)

(aa) Structure pale, beige. Roots of variable types. Presence of hairs or projections on surface; if not, record "Herbacae" ........ Cyperaceae (Pls. 17-11, 17-12, 29-8)

(b) Stem dark, more or less reddish, spongy appearance. Foliar scars alternate, perpendicular, or nearly so, to the stem axis ....... Sphagnum sp. (PIs. 14-8, 24-11)

(bb) Stem dark, variable appearance. Foliar scars often formed of basal remains of leaves. If leaves present, refer to key to leaves; if absent $\ldots \ldots \ldots \ldots \ldots$ .............................. Bryale (Pls. 15-11,24-1, 24-3, 24-6) 


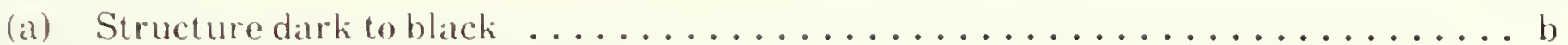

(a) Structure pale, contains at least two eentral ligneous axes .............. c

(b) Root network nondendritic, that is, roots of the order $\mathrm{N}+1$ attached in perpendicular fashion to roots of the order $\mathrm{N}$ : roots of the order $\mathrm{N}+2$ rare or nonexistent;

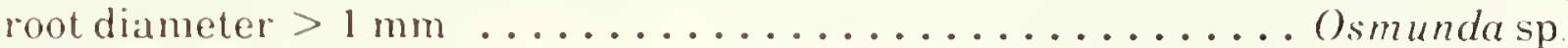

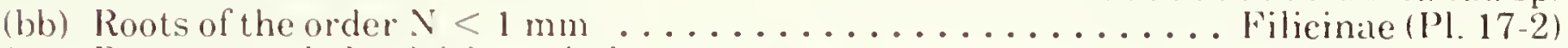

(c) Root network dendritic; no hairs on roots ........... Herbacare (Pls. 13-7, 9-3)

(ce) Specimen clearly elongate and smooth. Nodes, if present, point-type, opposed, more or less spaced, and usually circular; single vascular sear . . . . . . . . . . . .................. Pilieinae (rachis) (Pls. 29-5, 30-1, 30-3, 30-6)

212

Nodes annular, discontinuous, formed of several root-insertion points. internodal spacing approximately $10 \mathrm{~cm}$, rhizome ligneous ................

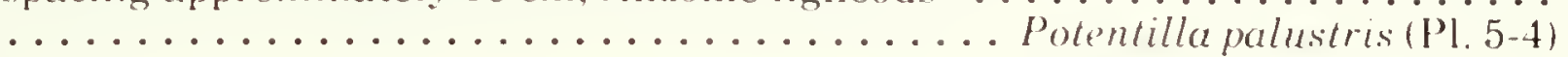

(a) Foliar scars often tri-verticillate: longitudinal grooves below each scar .........

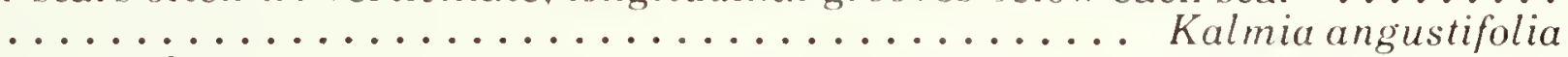

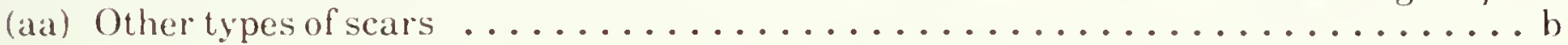

(b) Structure black, more or less rectilinear, often intermixed with peaty sediments ...

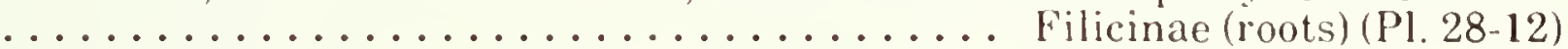

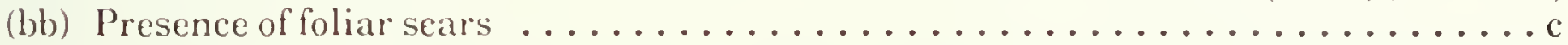

(c) Twig with small diameter (approximately $3 \mathrm{~mm}$ ), rectilinear; alternating foliar scars

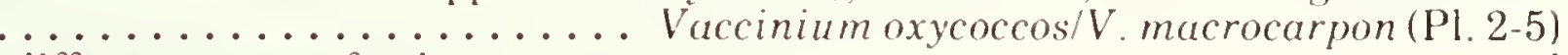

(ce) Other different types of twigs .......................... d

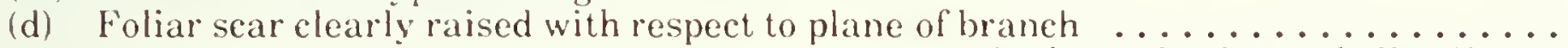

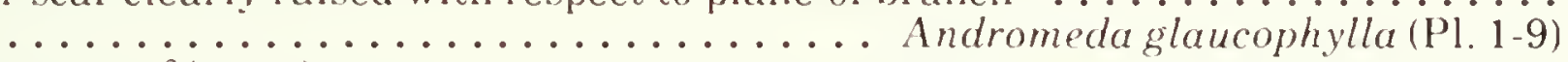

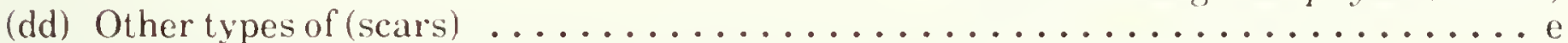

(e) Vascular scar, single, linked to bud by miniscule ramp; glabrous branch .......

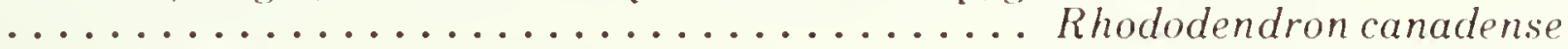

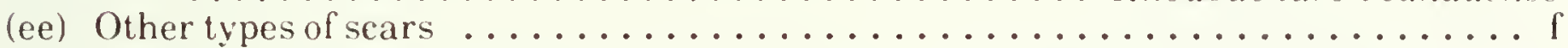

(f) Annual branchlet, pubescent. Plane of foliar scar at same level as that of branchlet

(1) Foliar scars only ....................... Lignosae (stem) (Pl. 13-2)

(2) Root scars only (axis often sinuous and with an asymmetric cross section .... $\ldots \ldots \ldots \ldots \ldots \ldots \ldots \ldots \ldots \ldots$ Lignosae (root) (Pl. 18. 12)

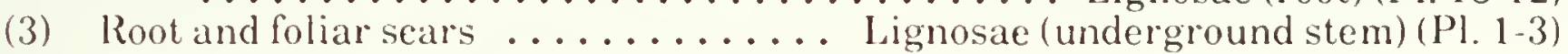

(a) Branchlet, if bark present, verrucose; bud, if present, ornamented on each side by a guard scale, acuminate ....Vaccinium angustifolium/V. myrtilloides (Pl. 2-1)

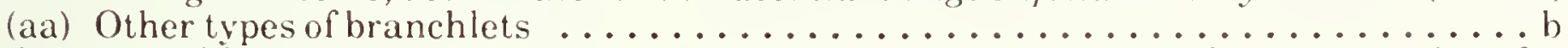

(b) Branchlets, clearly tuberculate, each tubercule representing the support site of a

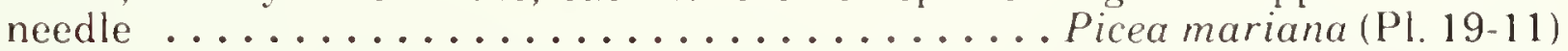

(bb) Branchlet having a few lenticels, and with bud being carried on a projection larger

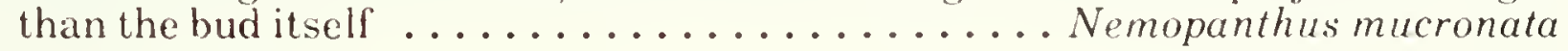

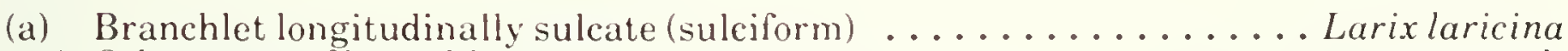

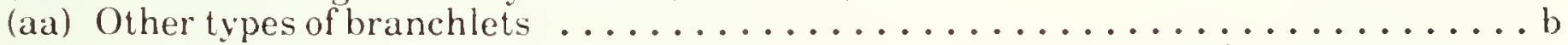

(b) Annual branchlet finely pubescent; branchlets $>2$ vears, striated, anastomotic ...

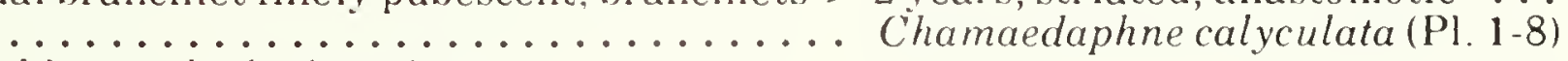

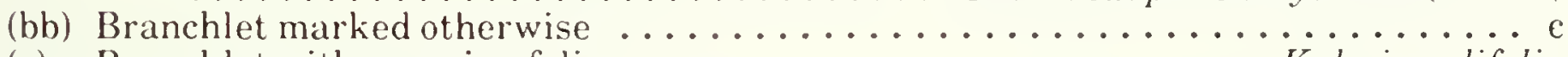

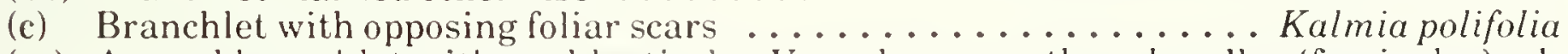

(ce) Annual branchlet with oval lenticels. Vascular scar: three bundles (fascicules), al-

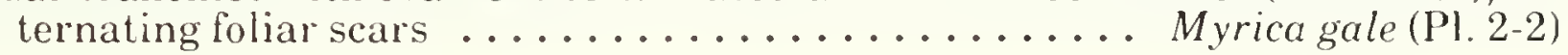

(a) Specimen black on surface, with a pale central axis

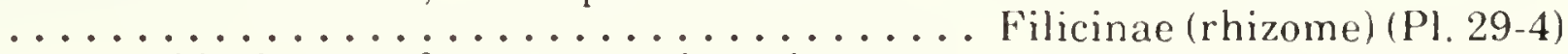

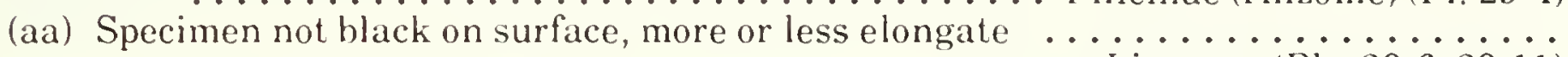
Lignosae (Pls. 29-6, 29-11) 
Branchlet flattened, covered with leaves of two sorts $\ldots \ldots \ldots \ldots \ldots \ldots$

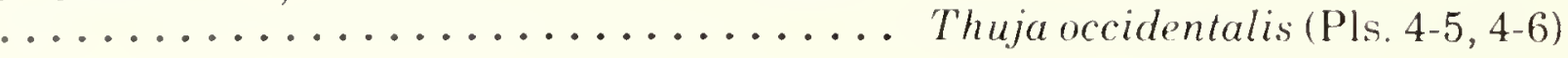

Black specimen (diameter $5-10 \mathrm{~cm}) \ldots \ldots \ldots \ldots$ Osmunda sp. (rhizome) 
This key is based on the identification of outline type and margin type, the form of the apex and base, and the cross section transverse to the major axis of the leaf.

2.1 Description of the classification criteria

2.1.1 Outline type

(1) Lanceolate-elliptic: Sphagnum sp.

(2) Oblanceolate: Myrica gale

(3) Linear: Larix laricina

(4) Other

2.1.2 Margin type

(1) Entire: Kalmia angustifolia

(2) Dentate over entire margin of leaf blade: Vaccinium angustifolium

(3) Dentate only near tip: Myrica gale

(4) Other

2.1.3 Type of apex

(1) Pointed: Picea sp
(2) Blunt: Kalmia sp.

(3) Emarginate: Abies balsamea

(4) Acuminate: Aulacomnium sp.

(5) Cuspidate: Plagiomnium sp.

2.1.4 Type of base

(1) Cuneiform-attenuate: Myrica gale

(2) Rounded: Kalmia sp., Chamaedaphne calyculata

(3) Truncate: Dicranum sp.

(4) Other

2.1.5 Cross section shape

(1) Elliptic: Polytrichum sp.

(2) Spatulate-linear: Osmunda sp

(3) Conduplicate-semicircular: Pinus banksiana

(4) Revolute: Andromeda glaucophylla

(5) Triangular: Pinus strobus:

(6) Rectangular: Picea sp.

2.2 Key to specific identification of leaves

\section{4}

(a) Petiole and underside of leaf tomentose-woolly; upper leaf surface colliculate ..... .....................................

(aa) Tip pointed-acuminate. Abaxial cover composed of straight, short hairs .......

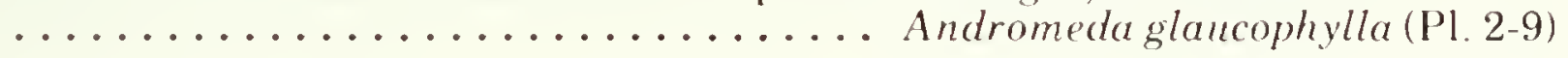

11124

Petiole curved and offset with respect to the major axis of leaf; length $<1 \mathrm{~cm} \quad \ldots$. ........................ Vaccinium oxycoccos (Pl. 3-5)

\section{3}

(a) Leaf opaque (coniferous), with scale-like form $\ldots \ldots \ldots \ldots \ldots \ldots \ldots$

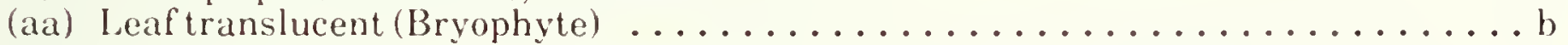

(b) Costa single, up to two-thirds length of leaf; cell broadly hexagonal ..........

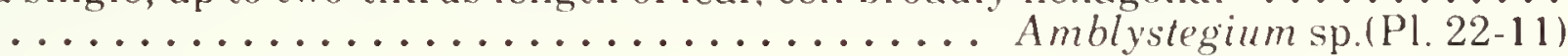

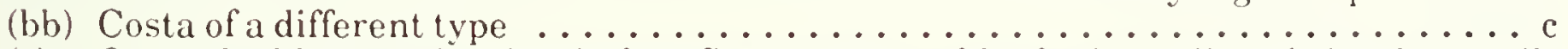

(c) Costa double, terminating before first quarter of leaf; alar cells subcircular, welldifferentiated. Leaves strongly cucullate at tip. Stem dark, red; junctions, if present, pinnate ............Pleurozium schreberi (Pls, 15-7, 12-11)

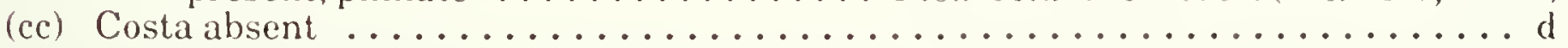

(d) Branch leaf complex dark brown. Leaves glossy, with cells elongate and sinuous; alar cells showing slight differentiation ......... Scorpidium sp. (Pl. 26-1)

(dd) Leaf cucullate, dull and whitish, detaching easily from the stem; leaf-blade composed of a network of complex cells ........... Sphagnum sp. (Pl. 15-1)

(e) Leaves of two types on branchlet; presence of resiniferous vesicle on underside of

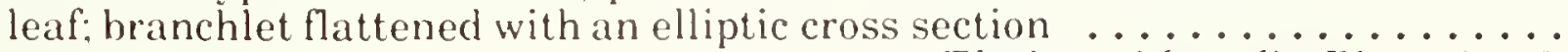

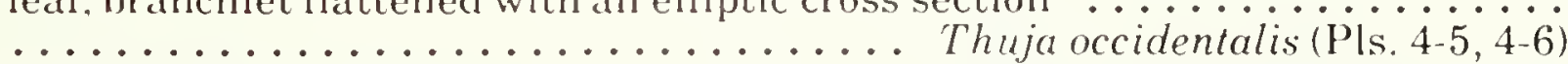

(ee) Leaves all the same, possessing dorsal resiniferous vesicle toward base; branch with a circular cross section .............. Juniperus horisontalis (Pl. 4-2)

\section{2}

(a) Leaf length $<6 \mathrm{~cm} \ldots \ldots \ldots \ldots \ldots \ldots \ldots$ Kalmia angustifolia (Pl. 14-3)

\section{2}

Leaf length $<1.8 \mathrm{~cm} \quad \ldots \ldots \ldots \ldots \ldots$ Vaccinium macrocarpon (Pl. 3-7) 
(a) Leaf plane, wrinkled or not, uncarenate, with costa extending beyond the upper half of leaf; branchlet, if present, hooked at tip; leaves more or less falciform . . . . . ........................ Drepanocladus sp. (Pls. 21-12, 22-7)

(aa) Leaf more or less revolute. Costa single, well visible, disappearing before reaching the apex. Foliar cells subcircular ........ Aulacomnium sp. (Pls. 31-8, 32-5)

12112

(a) Leaf veins not reaching margin; petiole pubescent; resembling Vaccinium myrtilloides ...................... Vaccinium anjustifolium (Pl. 3-1)

(aa) Veins obscure, petiole glabrous, presence of small dots (peltate), more or less glossy, on the whole leaf surface ........ Chamaedaphne calyculata (Pls. 2-7, 4-11)

12222

Veins parallel and pinnate, terminating at leaf margin; margin crenelate ......

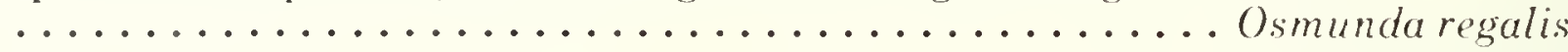

13133

Costa terminating slightly before leaf tip; paraphyllia and propagula present at leaf axes Climacium sp. (Pls 11-9, 11-12)

13232

Costa complete; margin doubly denticulate Mnium sp.

\section{1}

Leaf often attached to stem. When unattached, base of leaf broadened and corresponding to sheath connected to stem. In the fossil state, denticulated portion at tip may be obscure ........... Polytrichum sp. (Pls. 25-3, 12-7)

13432

Costa double and obscure at base of leaf. Several paraphyllia present at base of each branch. Branch leaves wrinkled and falciform; stem leaves larger than those of branch leaves. Branches pinnate ........ Ptilium crista-castensis (Pl. 12-4)

13433

(a) Leaves gently acuminate from base to tip ........ Dicranum sp. (Pls. 12-2, 12-3)

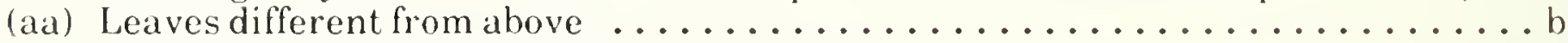

(b) Leaves cucullate and strikingly dentate at tip. Paraphyllia numerous; costa double. Branches 2-3 times pinnate in one plane

...................... Hylocomium splendens (Pls. $12-5,12-6)$

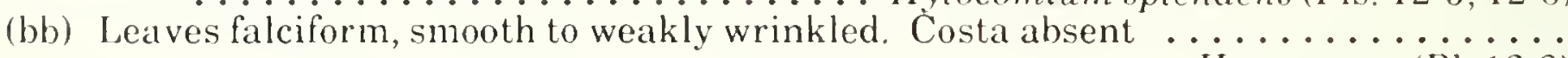
.......................... Hypnum sp. (Pl. 12-8)

13532

Costa complete; foliar cells polygonal; margin simply denticulate . . . . . . . . . .

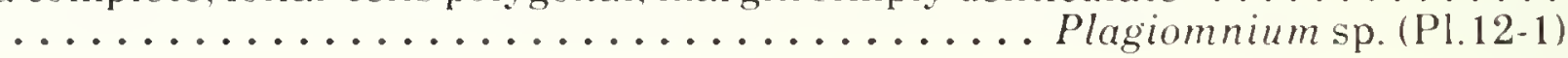

23212

Presence of tiny glandular hairs (white in fossil state) on both sides of leaf . . ....

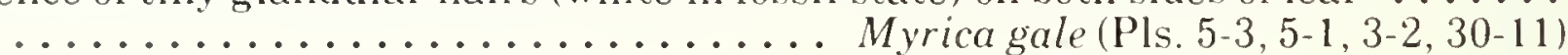

\section{4}

(a) Leaf outline spatulate-linear; width approximately $2 \mathrm{~mm}$; surface glossy in fossil

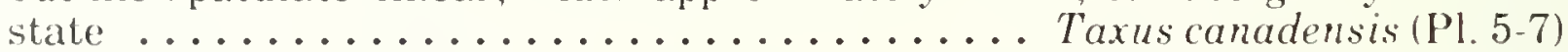

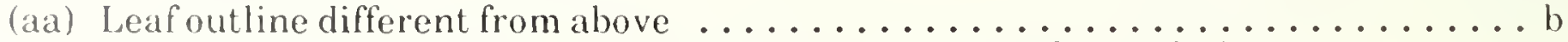

(b) Apex pointed-acuminate. Abaxial surface composed of straight hairs .........

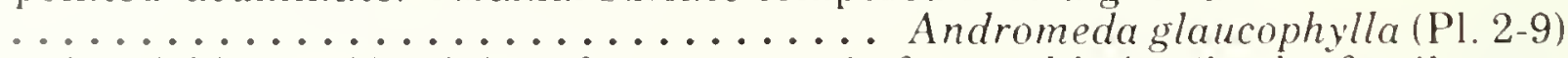

(hb) Apex pointed-blunt. Abaxial surface composed of curved hairs (in the fossil state, there is a possibility of confusion with (b)) ........ Kalmia polifolia (Pl. 15-5) 
(a) Resiniferous canals intermittent. Some canal-associated swelling apparent on sur-

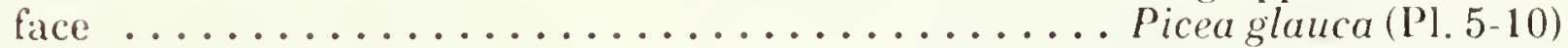

(a) Resiniferous canals continuous. Two continuous lines sometimes visible on surface $\ldots \ldots \ldots \ldots \ldots \ldots \ldots \ldots$ Picea mariana $(\mathrm{Pls} .15-2,5-6,5-12)$

31245

Leaves attenuate in long direction from base toward tip. Leaf base often curved. Petiole included within overall length of leaf. Resiniferous canals laterally exiting $(12 \mathrm{X}) \ldots \ldots \ldots \ldots \ldots \ldots \ldots$. . . . . . . . . . 17-3)

31341

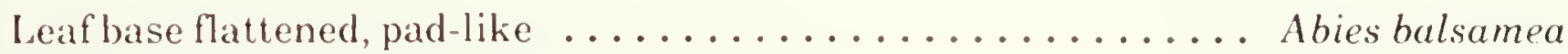
31433

Leaf opaque, with a whitish row of stomata underneath $\ldots \ldots \ldots \ldots \ldots \ldots$ $\ldots \ldots \ldots \ldots \ldots \ldots \ldots$ Juniperus communis (Pl. 6-1)

\section{5}

(a) Resiniferous canals visible on smooth face of leaf ........... Pinus resinosa

(a) Resiniferous canals not visible ............. Pinus banksiana (Pl. 5-8)

32145

Leaves usually denticulate on the three corners at apex; base often decomposed and

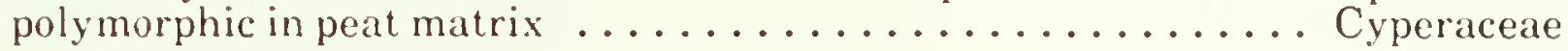

33212

Leaf glossy in fossil state. Petiole generally straight and offset with respect to leaf

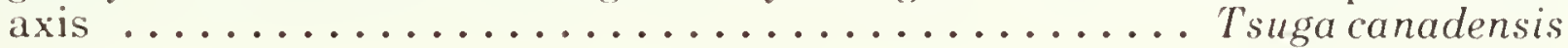

41133

(a) Leaf spiny, without resiniferous vesicle .......... Lycopodium sp. (Pl. 31-10)

(aa) Leaf spiny, with resiniferous vesicle on dorsal face ......... Thuja occidentalis 
This key is based on identification of the outline characteristics, shape of cross section perpendicular to the major axis of the specimen, and type of surface relief. It is used for the identification of seeds and of plant structures that might resemble seeds. In determining the characteristics that follow, no consideration has been given to appendices or projections.

\subsection{Description of the classification criteria}

\subsubsection{Outline characteristics}

(1) Circular: Menyanthes trifoliata

(2) Angular: Chamaedaphne calyculata

(3) Elliptic: Andromeda glaucophylla

(4) Lanceolate: Picea sp.

(5) Elongate-linear: Ledum groenlandicum

3.1.2 Shape of cross section perpendicular to the major axis of the specimen

(1) Circular: Cenococcum sp.

(2) Triangular: Carex oligosperma

(3) Elongate-elliptic: Abies balsamea

\subsubsection{Type of surface relief}

The characteristics of the seed surface are important. They should be examined on the flattened surfaces (if possible), far from the hilum, if present, and at a magnification of $10 \mathrm{X}$ (hand lens). The illustrated glossary contains examples of the types of relief.

Five alternatives are proposed:

(1) Glossy: An absence of any structure capable of defracting the illumination light must be noted. A luminous point must be apparent on the surface of the seed At higher magnification, there might be a network of some kind visible, but this detail is not taken into account, for example Menyanthes trifoliata

(2) Dull: The tegument surface reflects little or no light. The outline of the luminous point defined in (1) is either scarcely visible or absent; type example: Scirpus americanus

(3) Reticulate, colliculate, scalariform An apparent relief prevents the surface from being regular, for example Chamaedaphne calculata.

(4) Sulcate: For example, Pinus banksiana

(5) Others

3.2 Key to specific identification of seeds

112

(a) Seed wrinkled close to hilum; hilum covering almost one quarter of surface. Tegument sometimes corrugate .............. Taxus canadensis (Pl. 7-2)

(aa) Specimen black, subspherical, having no visible features on the surface. Diameter $0.3-5 \mathrm{~mm}$. Belongs to a lower fungus order ....................................... 31-12)

131

(a) Seed having hilum at edge, with a thick tegument. In the fossil state seed often broken in half ................. Menyanthes trifoliata (Pl. 9-11)

(a) Seed usually black, with slightly concave surface. In the fossil state seed often with a few spiked bristles at one of extremities $\ldots \ldots \ldots \ldots \ldots \ldots \ldots$ Polygonum lapathifolium $(\mathrm{Pl}$. $11-8)$

(a) Seed having an appendage at each end $\ldots \ldots \ldots \ldots \ldots \ldots \ldots \ldots \ldots$

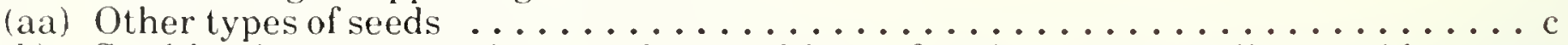

(b) Seed having a narrowing trend toward base, forming an appendix; turgid appear-

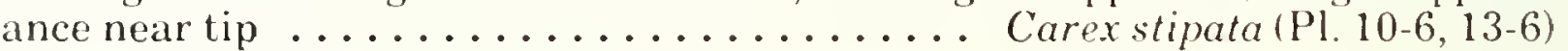

(bb) Other types of seeds, with blunt tip and hase more or less stipitate ..........

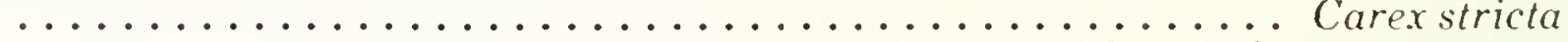

(c) Seed, usually brown-beige; hilum located on one more or less flat surface .......

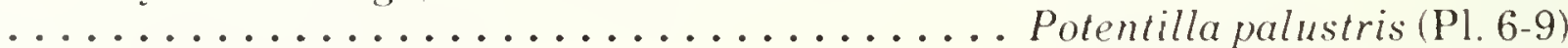

(cc) Seed with a "trap-door" at side ............ Potamogeton sp. (Pl.31-5) ........................ Larix laricina (mesoblast) (Pl. 16-11) 
(a) Small seed (approximately $1 \mathrm{~mm}$ ); at higher magnification, tegument is reticulate ........................ Vaccinium myrtilloides (Pl. 6-4)

(aa) Seed (approximately $3 \mathrm{~mm}$ ) with flattened base and bent style

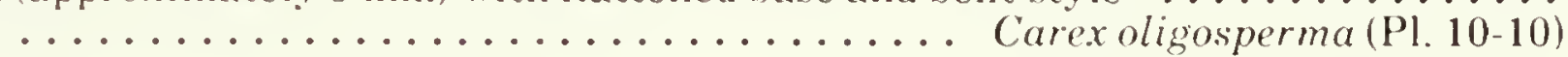

223

Seed having a scalariform network over at least one face, often resembling the shape of a piece of pie ..................... Wa maedaphne calyculata (Pl. 6-2)

232

(a) Seed having elongated resiniferous pockets up to and beyond half the seed length

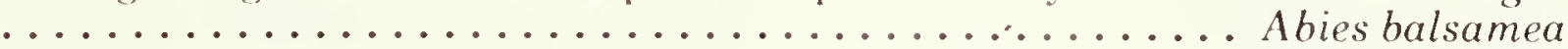

(aa) Seed shriveled lengthwise, with a noticeable fold or crease in the middle; style persistent ............................... carinita (Pl. 11-4)

312

(a) Specimen composed of less than 10 scales; tip of at least the first two scales upturned slightly (opposed) .................. Thuja occidentalis (cone)

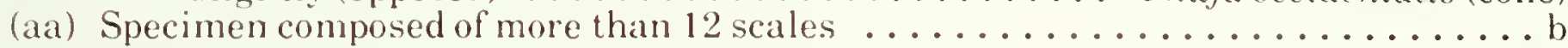

(b) Specimen elongate and cylindrical, in excess of $2.5 \mathrm{~cm}$; outline of tip of wing at least $1.5 \mathrm{~mm}$ from tip of scale .............. Picea glauca (cone) (Pl. 7-3)

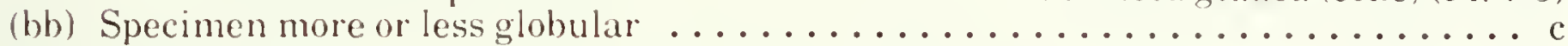

(c) Scales thicker at tip, nondenticulate and subelliptic: top side of scale more or less

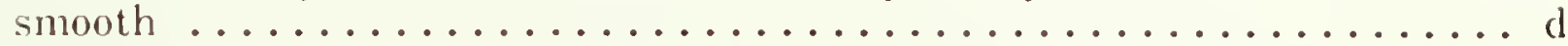

(cc) Scales thin, subcircular, with a denticulate tip; top side of scale rugose ........

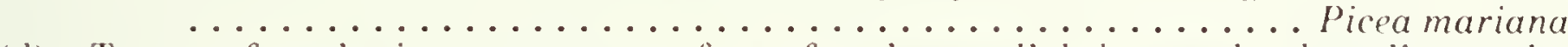

(d) Traces of seed wings on concave lace of scale parallel: bracteal subtending scale, emarginate and flabelliform ............................. canadensis

(dd) Traces of seed wings on concave face of scale divergent; bracteal clearly mucronate; cone well-preserved, embossed at base ... Larix laricina (cone scale) (Pl. 16-4)

(a) Seed truncate at base; style long and straight .......... Carex limosa (Pl. 11-3)

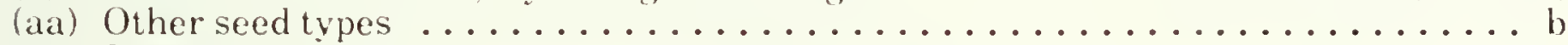

(b) Seed approximately $5 \mathrm{~mm}$; dorsal surface sulcate $\ldots \ldots \ldots \ldots \ldots \ldots \ldots$ .................................... 6emanthus mucronata (Pl.

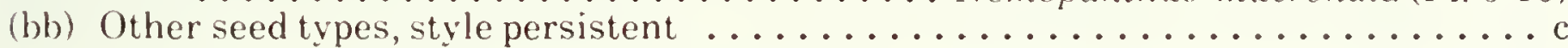

(c) Seed corners paler than sides, approximately $1.5 \mathrm{~mm} \ldots \ldots \ldots \ldots \ldots \ldots$ $\ldots \ldots \ldots \ldots \ldots \ldots \ldots \ldots \ldots$ Carex paupercula $(\mathrm{Pl} .10-5)$

(cc) Corners same color as sides; approximately $3 \mathrm{~mm}$; perigynium pubescent .......

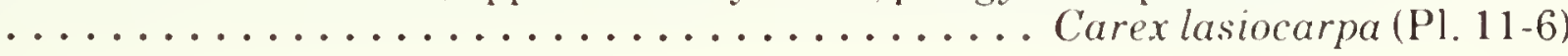

331

Seed small (approximately $2 \mathrm{~mm}$ ), with hilum on the edges at tip $\ldots \ldots \ldots \ldots$ $\ldots \ldots \ldots \ldots \ldots \ldots \ldots \ldots \ldots$ Andromeda glaucophylla $(\mathrm{Pl}$. 6-6)

(a) Specimen dark or pale, composed of an assemblage of leaves. (Partial desiccation is an aid in verification . ................. refer to Key to leaves)

(aa) Unadorned specimen (seeds) .................... b (Carex spp.)

(b) Seed with angular outline; tip blunt; base more or less cuneiform; sides converging

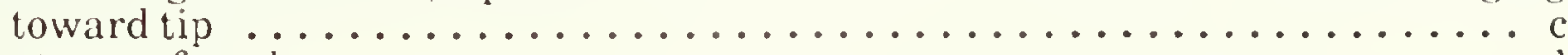

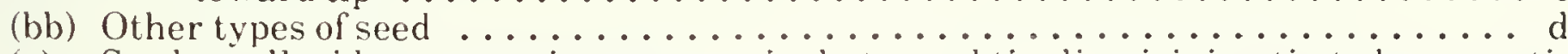

(c) Seed small; sides converging progressively toward tip; line joining tip to base, rectilinear from one side of seed .............. Carex cephalantha (Pl. 10-8)

(cc) Seed with sides converging abruptly toward tip. Line joining tip to base, not rectilinear ............................................. 10-9)

(d) Seed with sides subparallel, having a subspatulate outline; style dehiscent, tip truncate, base angle $<90^{\circ} \ldots \ldots \ldots \ldots \ldots$ Carex trisperma (PI. 10-12)

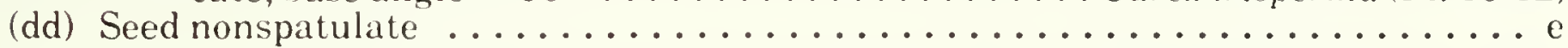

(e) Seed with imperfect bilateral symmetry; style persistent, base angle $<90^{\circ} \ldots \ldots$

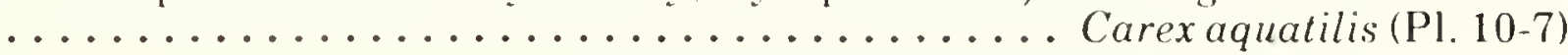




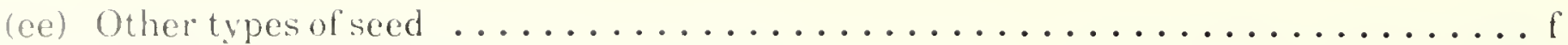

(f) Tip blunt, base angle approximately $90^{\circ} \ldots \ldots \ldots \ldots \ldots$ Carex canescens (P1 10-11)

(ff) 'lip truncate, base more or less stipitate ............. Carex chordorrhiza

412

(a) Seed speckled overall (length 3.8-7.5 mm), shaped like an elongated disk ...... f

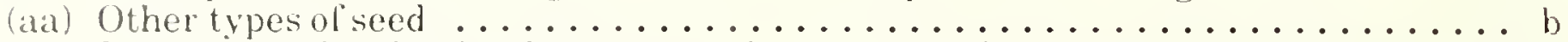

(b) Specimen pale, elastic when squeezed, composed of several leaves intimately imbricated and resembling a seed ......... Sphagnum sp. (apical bud) (Pl. 22-6)

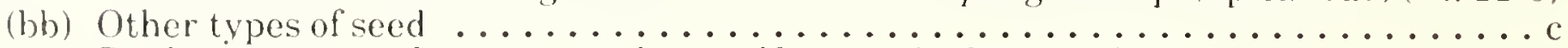

(c) Seed truncate, pale at one end, cuneiform-apiculate at the other: length approxi-

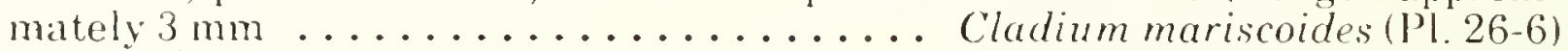

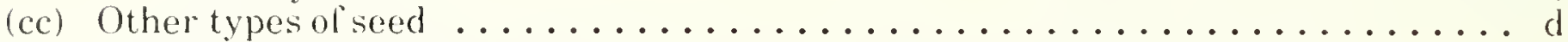

(d) Seed appendiculate at one end; sometimes partially covered by a membrane ......

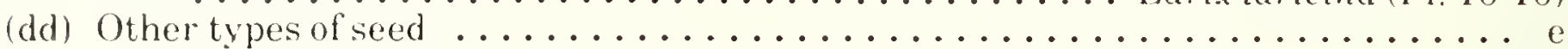

(e) Seed pale, with longitudinally arranged resiniferous pockets .............

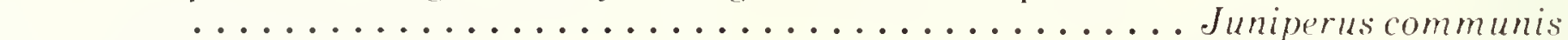

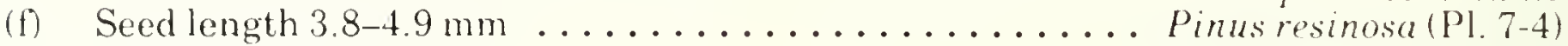

(ff) Seed length $6.0-7.5 \mathrm{~mm} \ldots \ldots \ldots \ldots \ldots \ldots \ldots$. . . . . . Pinus strobus (Pl. 6-11)

(a) Seed with trianguiar outline; length variable $(1-2 \mathrm{~mm}$ to $2-3 \mathrm{~mm}) \ldots \ldots$

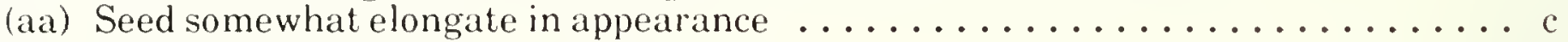

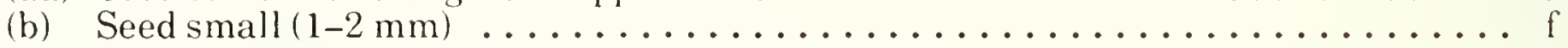

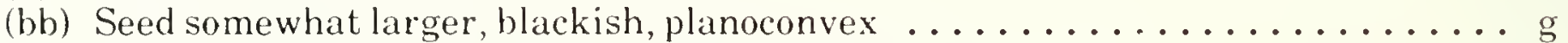

(c) Seed with blunt tip, without appendix; base slightly tapered and more or less stipi-

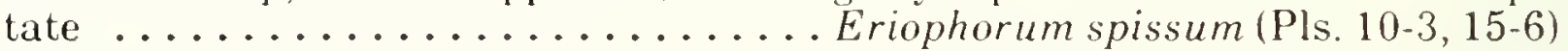

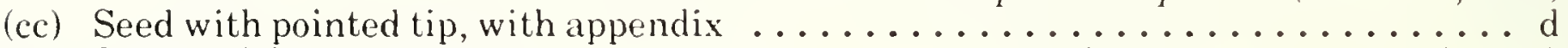

(d) Seed with blunt corners ............... Eriophorum virginicum (Pl. 10-4)

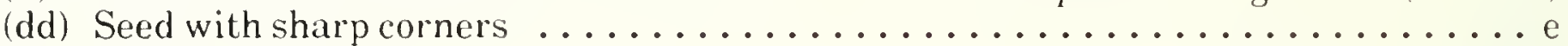

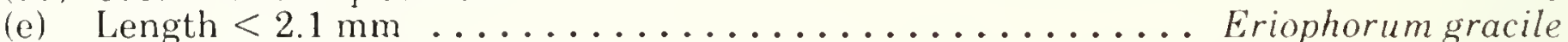

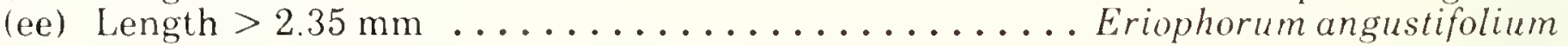

(f) Seed corners paler than faces; tip of perigrnium straight and clearly bidentate ....

(f) Coners same color as faces, tip of perignium curved seed tip truncate and mucron-

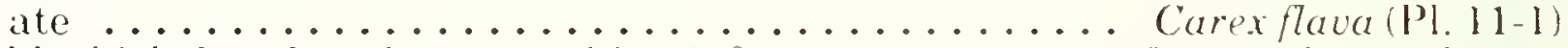

(g) Seed blackish; basal angle approaching $90^{\circ} \ldots \ldots \ldots \ldots$...... Scirpus heterochaetus

(gg) Seed with basal angle approaching $45^{\circ} \ldots .$. Scirpus acutus/S. validus (PI. 24-4)

431

Seed glossy, with a more-or-less globular projection at tip

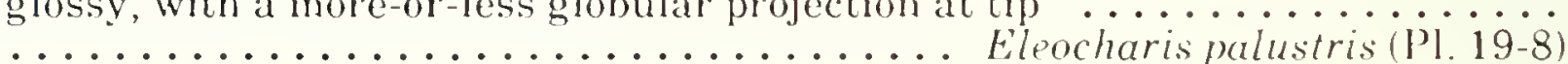

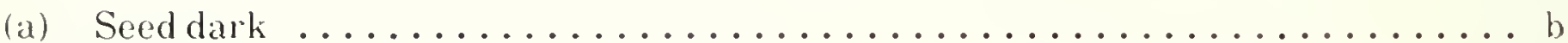

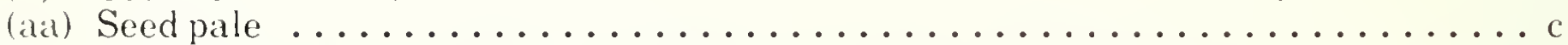

(b) Seed having some traces of resiniferous pockets; pockets small, length not exceeding

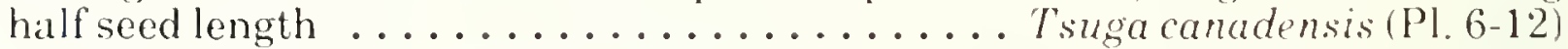

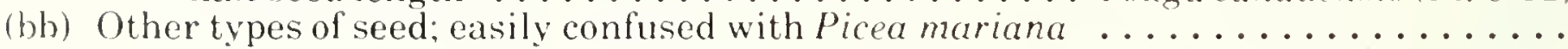

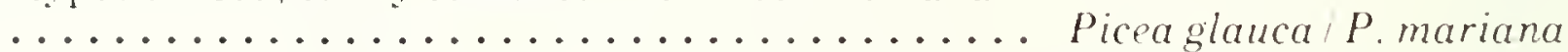

(c) Seed tapered at both ends: clear demarcation between style and body of seed .....

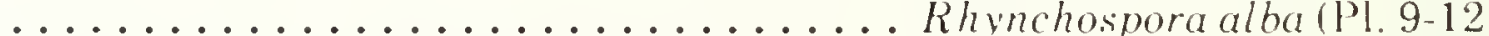

(cc) Seed truncate at one end. At higher magnification (30X), traces of the two fleshy wings of the fruit noticeable at base of seed $\ldots \ldots \ldots \ldots$ Myrica gale (finit without wings) (Pl. 6- 7 )

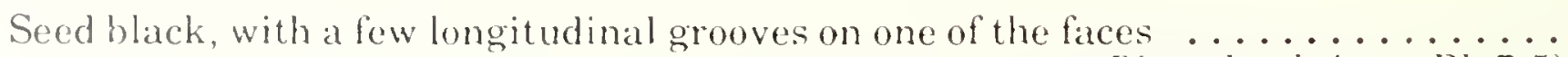

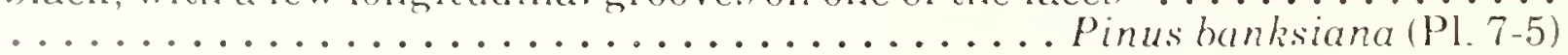




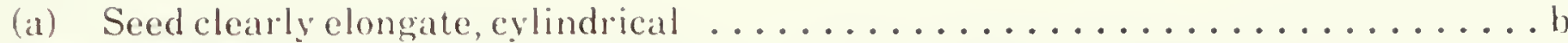

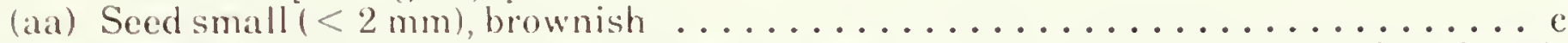

(b) Seed reticulate at one end and striate at the other ......... Callapalustris

(bb) Seed with triangular cross section at one end ........ Carex pauciftora (Pl. 11-2)

(c) Seed with a very visible ridge (cord) traversing length of seed $\ldots \ldots \ldots \ldots \ldots \ldots$ ........................... Vaccinum oxycoccos (Pl. 6-3)

(cc) Other types of seed, with a small black spot at each end $\ldots \ldots \ldots \ldots \ldots \ldots \ldots$

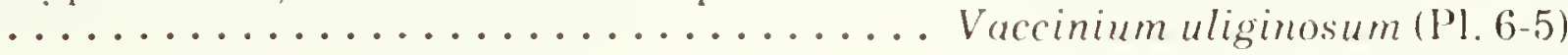

522

Seed pale, approximately $5 \mathrm{~mm}$; dorsal surface sulcate (refer also to 322 ) . . . . . . .................................. 6emonthus mucronata (P1. 10)

531

Seed tapered at both ends ...... Carex sp. (Ovales) (Carex sp. two-sided) (Pl. 18-3) 532

(a) Seed winged, with a few traces of elongated resiniferous vesicle .....................

(aa) Seed often with a few barbed bristles a base, extending beyond tip, or nearly so

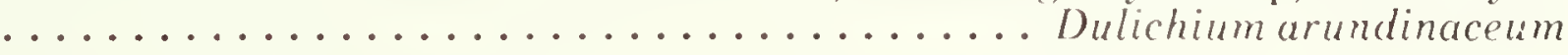


This key includes the following objects: fruit, hud scales, opaque bark bits, wood fragments, mesoblasts, oogoniums, hydathodes, sporangia, opercula, ephippia, statoblasts, sclerotia, and mycorrhizae.

The key is based on the outline type, form of the cross section perpendicular to the major axis, and type of structures noted on the specimen.

\subsection{Description of the classification criteria}

\subsubsection{Outline type}

(1) Circular: Fruit of Chamaedaphne calyculata

(2) Hemicyclic: Case (ocrea) of Equisetum sp.
(3) Elliptic: Cone of Larix laricına

(4) Lanceolate: Nodule of Alnus rugosa

(5) Spatulate-linear: Bark of conifers

4.1.2 Form of the cross section perpendicular to the major axis

(1) Circular: Mesoblast of Larix laricina

(2) Semicircular: Operculum of Sphagnum spp.

(3) Elliptic: Fruit of Myrica gale

(4) Lanceolate:

(5) Spatulate-lanceolate: Rachis of the Filicinae

4.1.3 Type of structures

(1) Unadorned: Wood fragment

(2) Composed of several elements: Mesoblast of Larix laricina

4.2 Specific identification key of the "VARIA"

112

Structure composed of a verrucose pedicel, scales (sepals), a globular part half enclosed by scales, and an appendix at the tip. The two first scales are opposed. Presence of microplates, especially on the scales and the pedicel .......... ..................... Chamaedaphne calyculata (fruit) (Pl. 28-7)

121

Specimen cupola- or dome-shaped. It covers and encloses the capsule of the Sphagnales .................... Sphagnum sp. (operculum) (Pl. 30-7)

132

Specimen triradiate, composed of two lateral wings and central seed. Possibly presence of whitish glands on fossilized specimen, if well preserved .......... ...................................... Myrica gale (fruit) (Pl. 6-7)

152

Specimen small, discoidal (approximately $1 \mathrm{~mm}$ ), with multiple glochidiate rays on periphery ............... Cristatella mucedo (statoblast) (Pl 31-7)

(a) Structure small (approximately $0.5 \mathrm{~mm}$ ), thin, hemilanceolate $\ldots \ldots \ldots \ldots$ .................................... (ephippium) (Pl 31-3)

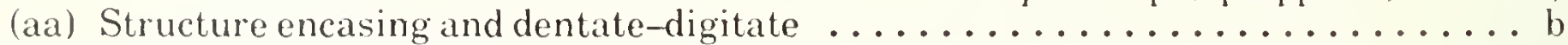

(b) Sheath (or fragment) pale at base, with blackish teeth. Central cavity covering half, or more, of stem or rhizome, if present. Lateral cavity invisible, or barely visible, to the naked eye ................. Equisetum fluviatile

(bb) Sheath of other type, but digitate ............. Equisetum sp. (Pl. 17-4)

311

Specimen small (approximately $0.5 \mathrm{~mm}$ ), ellipsoidal, surface covered with helicoidal ridges (more than eight) ............. Chara sp. (oogonium) (Pl. 31-4)

312

(a) Specimen (approximately $1 \mathrm{~mm}$ ), composed of more than 10 scales; if well-preserved, embossed at the base (refer also to 312 , Key to seeds) . ............... ....................................... laricina (cone) (Pl. 16-4)

(aa) Specimen cylindrical, composed of several rows of scales intimately imbricated (refer also to 212, Key to seeds) ........... Larix laricina (mesoblast) (Pl. 16-11) 
(a) Structure thin and elongate (approximately $1 \mathrm{~cm}$ ), resembling exactly the "finger and nail" ............... Scheuchzeria palustris (hydathode) (Pl. 9-9)

(a) Structure dult, finely lined, with corners somewhat rounded (mechanical erosion), composed of tubular microfibers ........... wood fragment (Pl. 13-3)

NOTE: The absence of "pores" in the annual rings is a diagnostic criterion for "conifer wood." The presence of "pores," visible by hand lens or by the naked eye, indicates "deciduous wood."

332

Specimen subglobular, small (approximately $0.2 \mathrm{~mm}$ ), composed of dark-colored axis and dehiscent vesicle ............ Polypodiaceae (sporangium) (Pl. 17-6)

412

Structure dark-colored, pyriform (approximately $5 \mathrm{~mm}$ ), mucronate at tip. A number of these structures may collect to form a dendritic assemblage ........

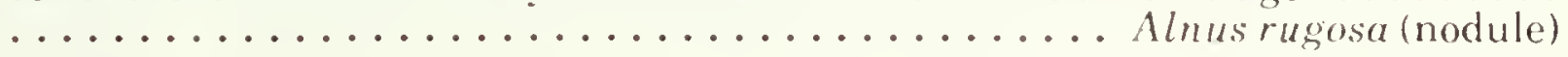

521 (refer to 331 (aa))

551

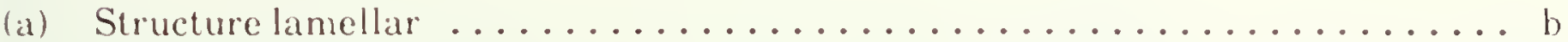

(aa) Structure elongate, more or less cylindrical; foliar scars, if present, opposed; vascular scar unique and irregular ................ Filicinae (rachis)

(b) Structure opaque, with subregular network of cells ..... Conifer (bark) (Pl. 13-5)

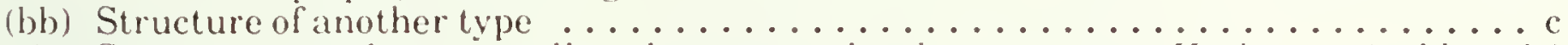

(c) Structure translucent, outline elongate or circular ...... Herbaceae (epidermis)

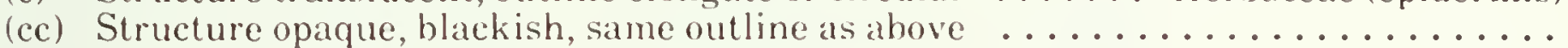
Filicinae (epidermis) (Pl. 29-10) 



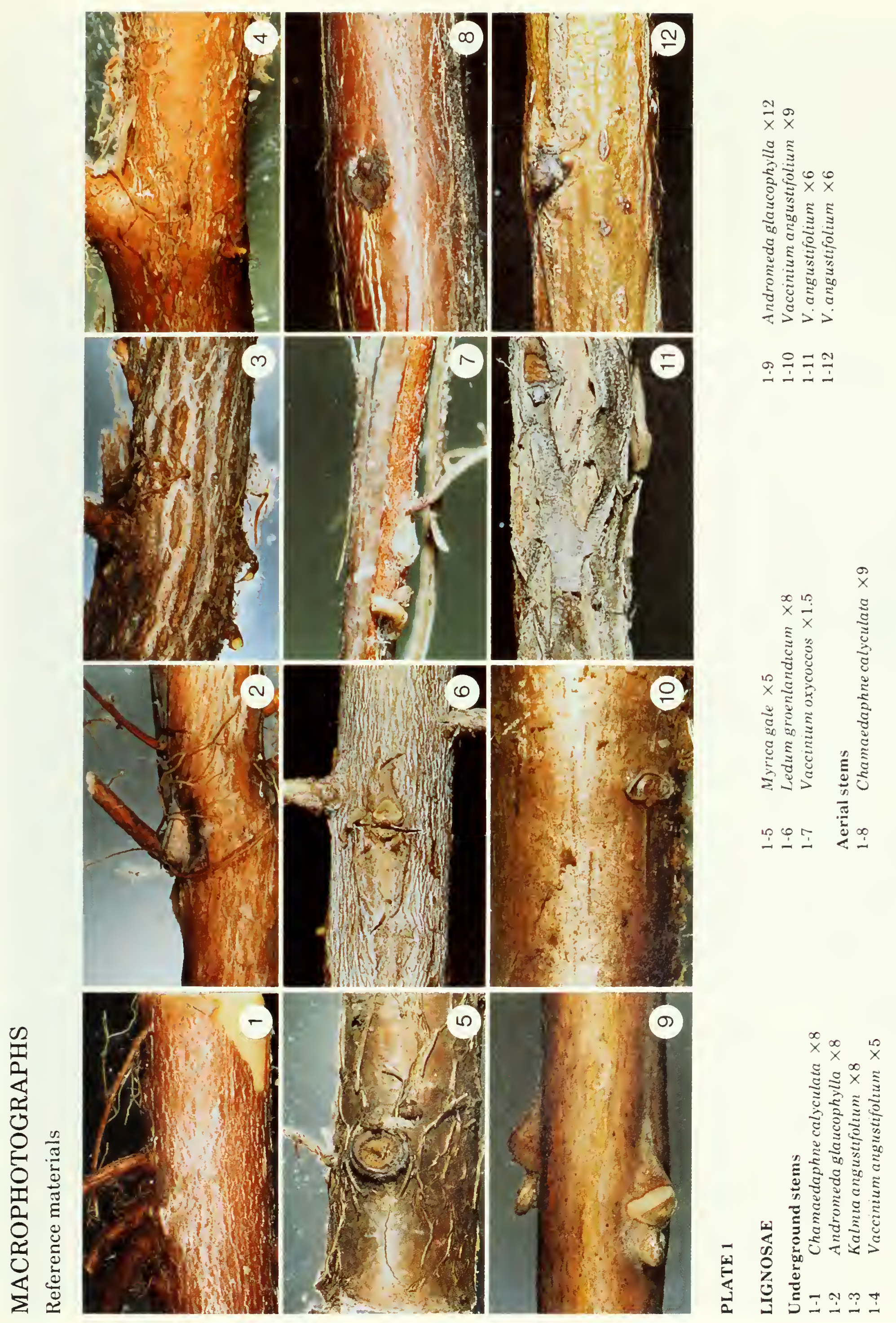



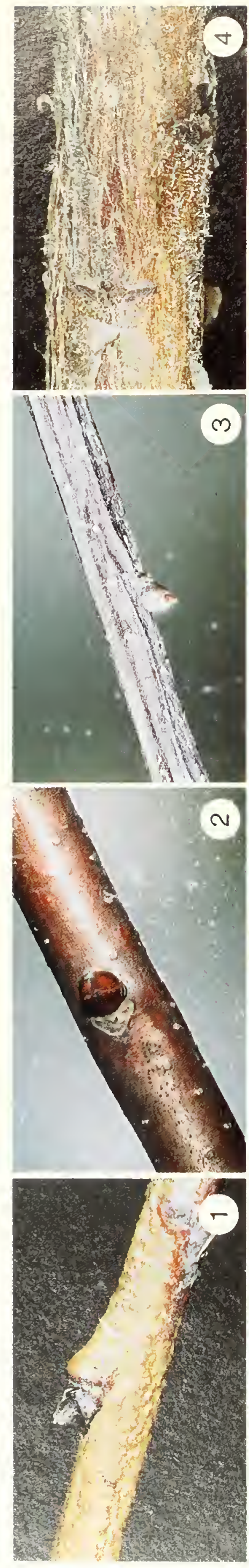
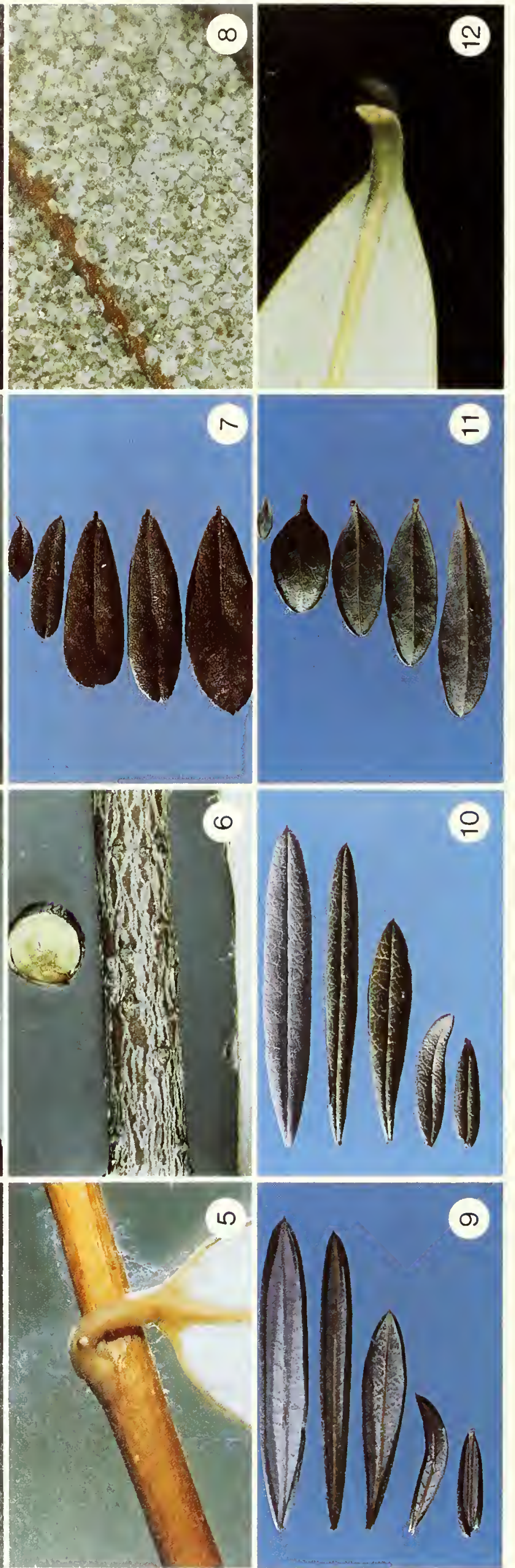

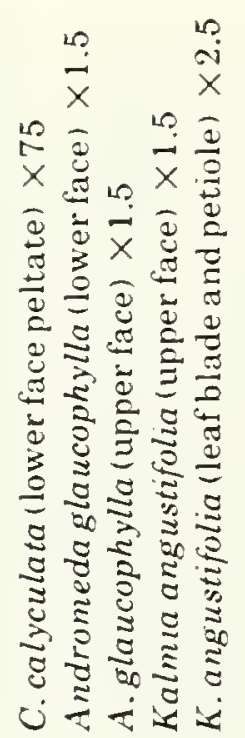

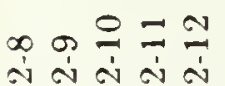
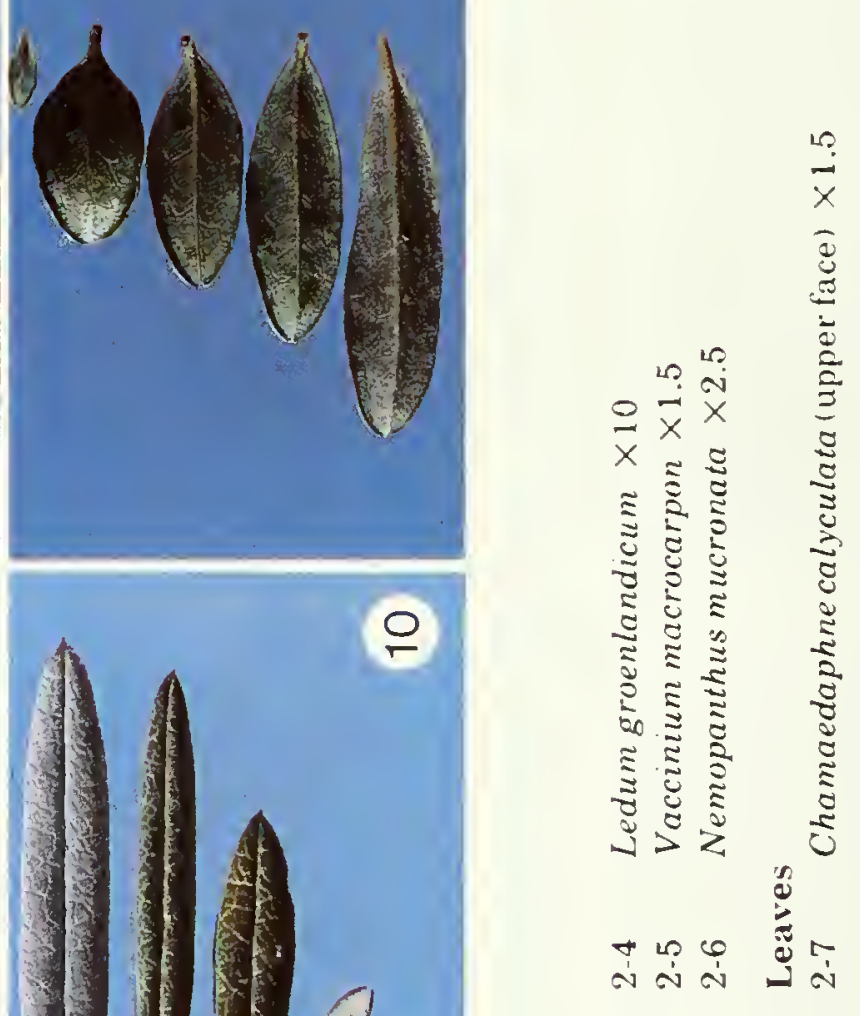

$\ddot{x}$

芌

옹 


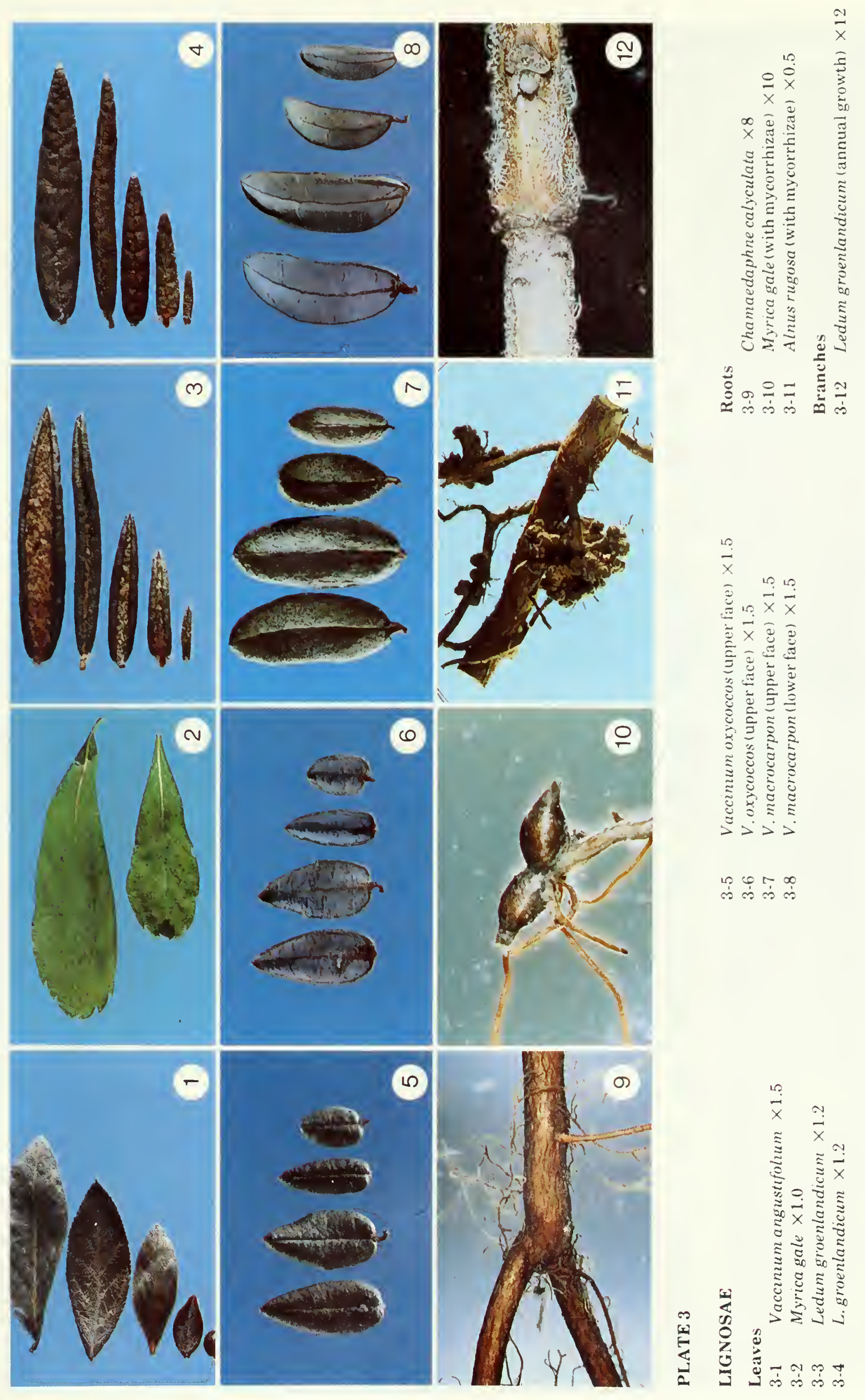




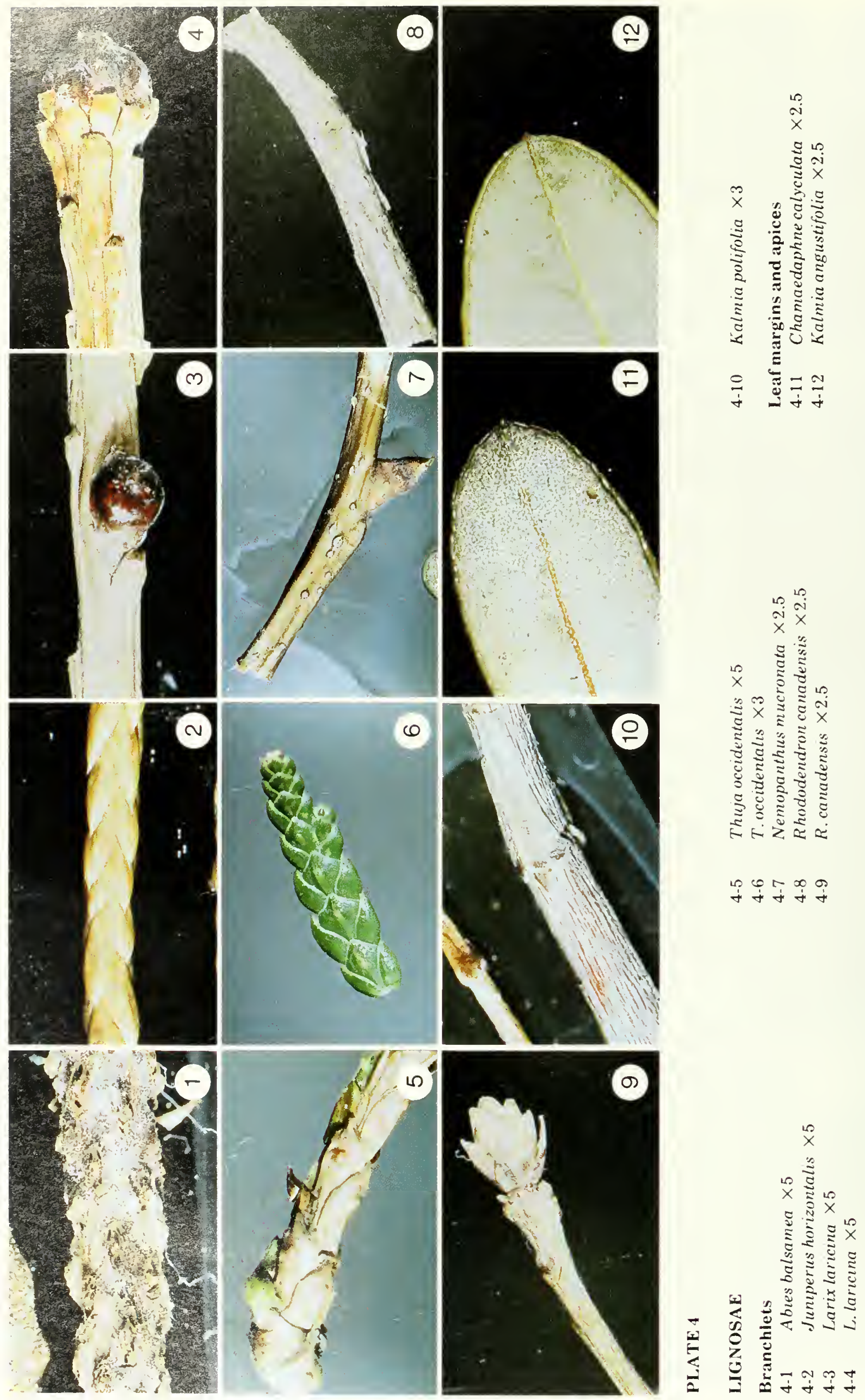




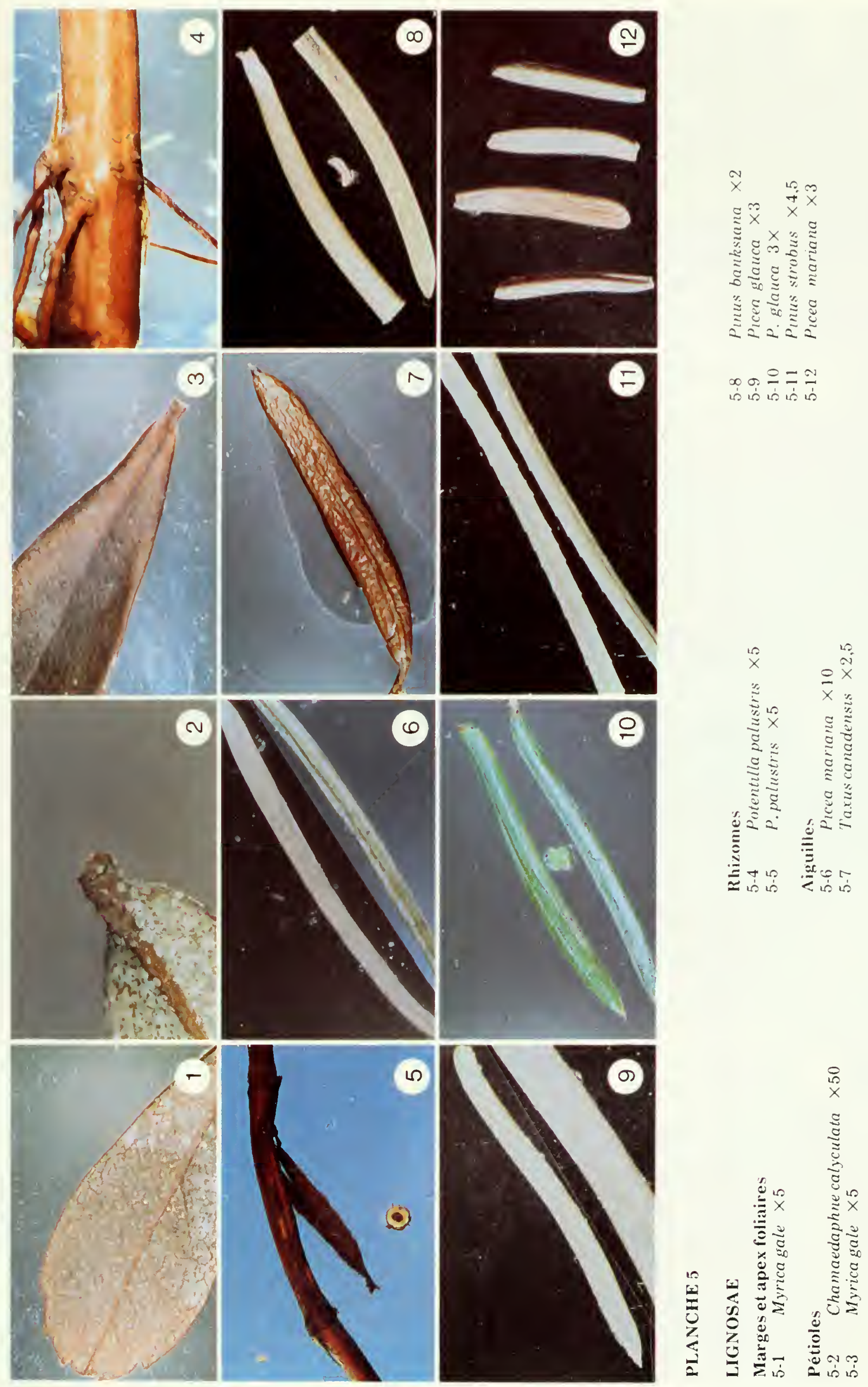




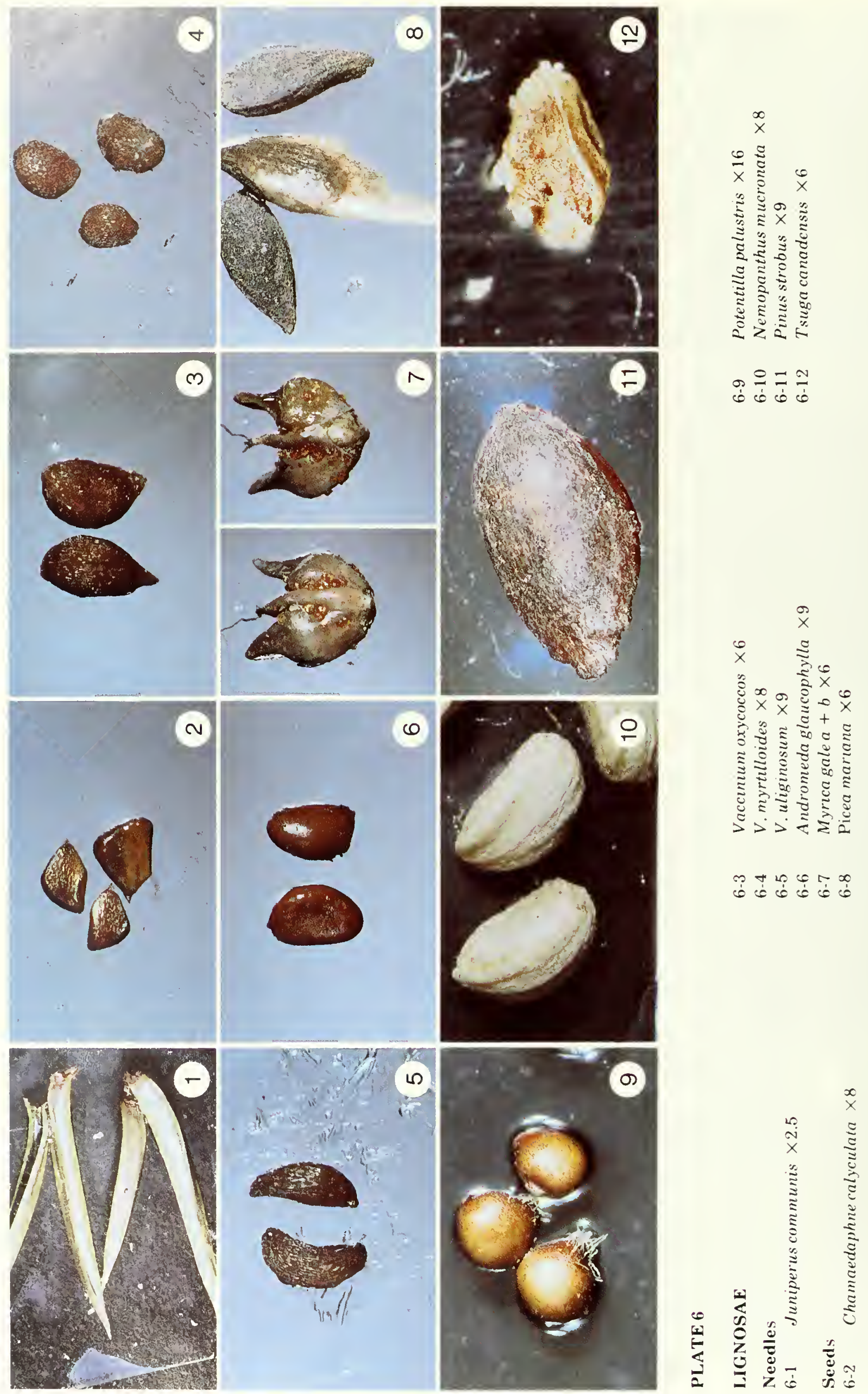




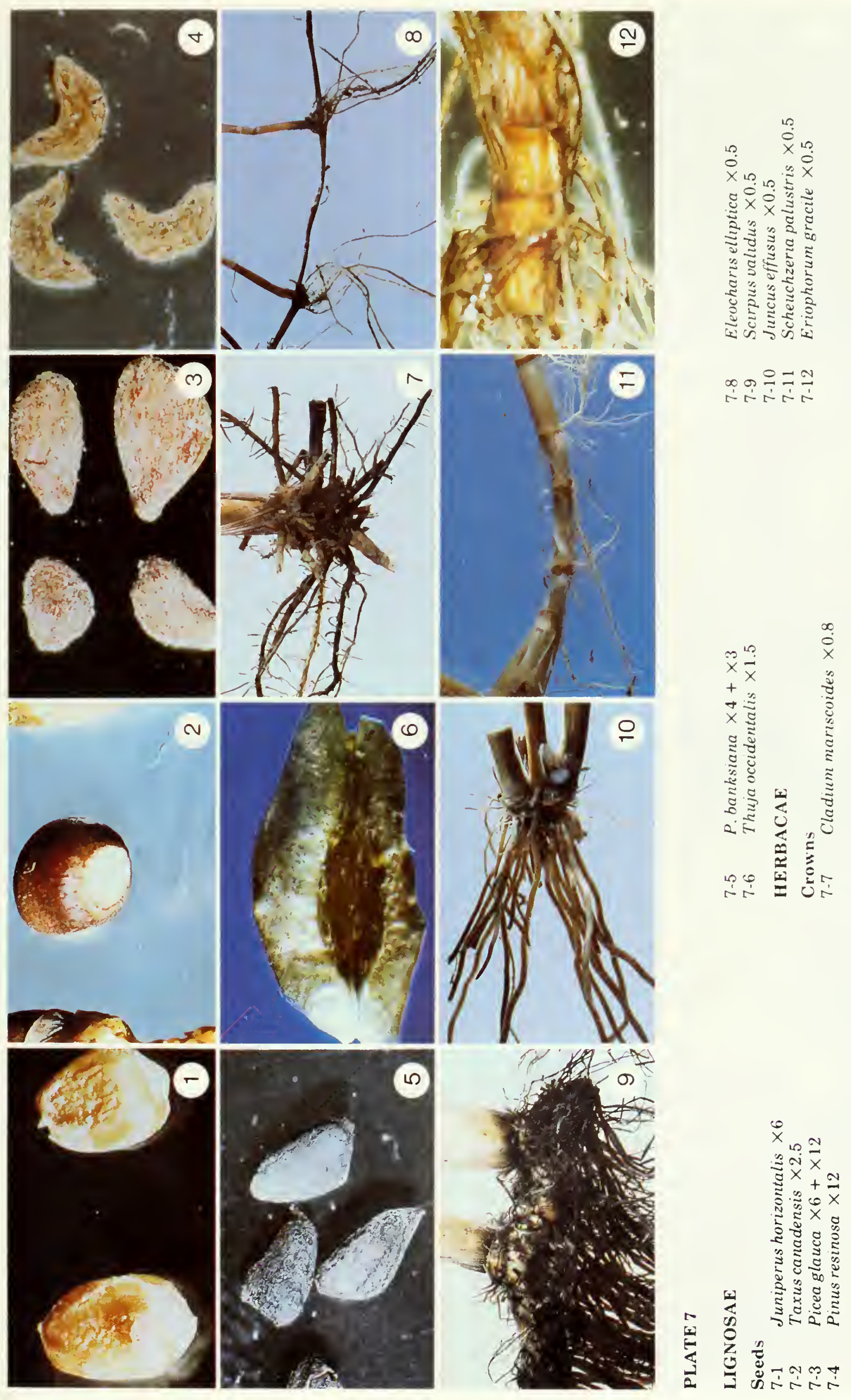




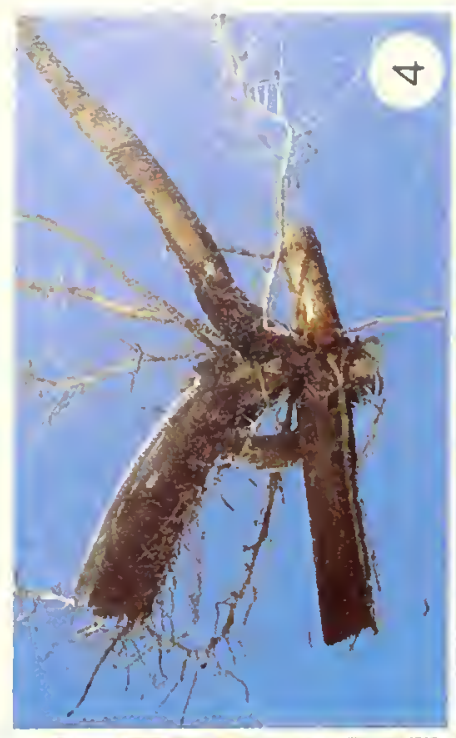

$11 \mathrm{n}$
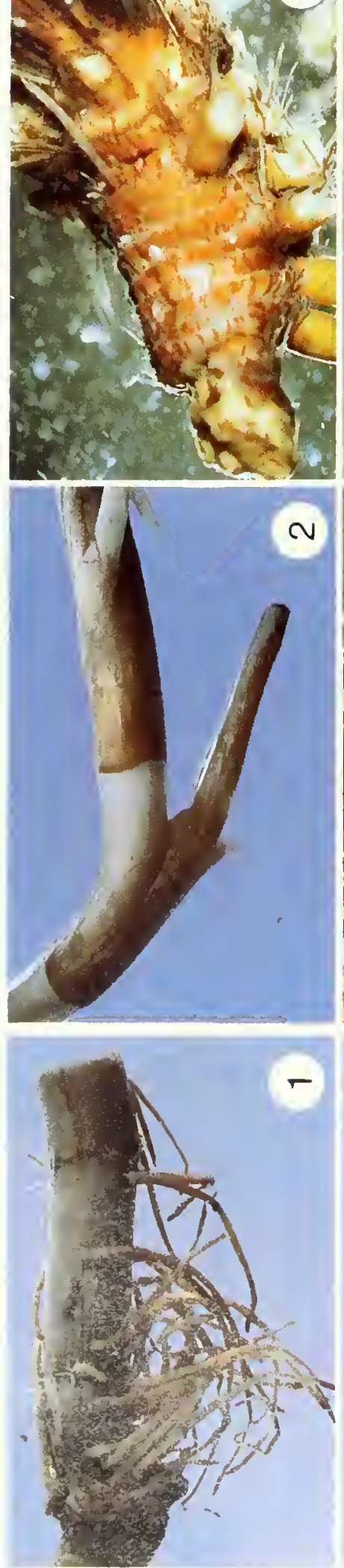
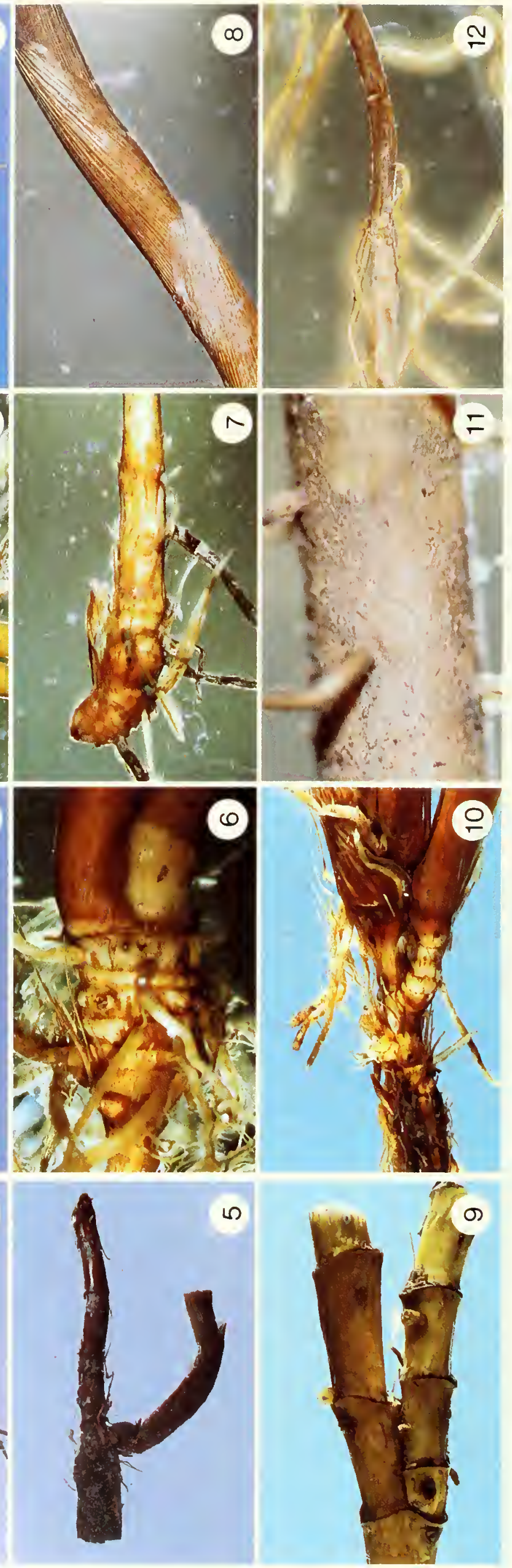

$\stackrel{0}{x} \stackrel{0}{x} \quad \frac{0}{x}$

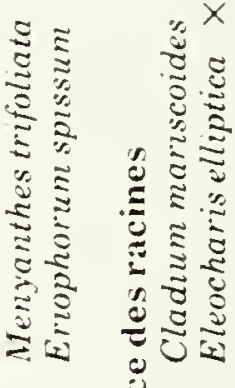

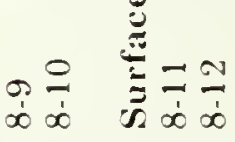
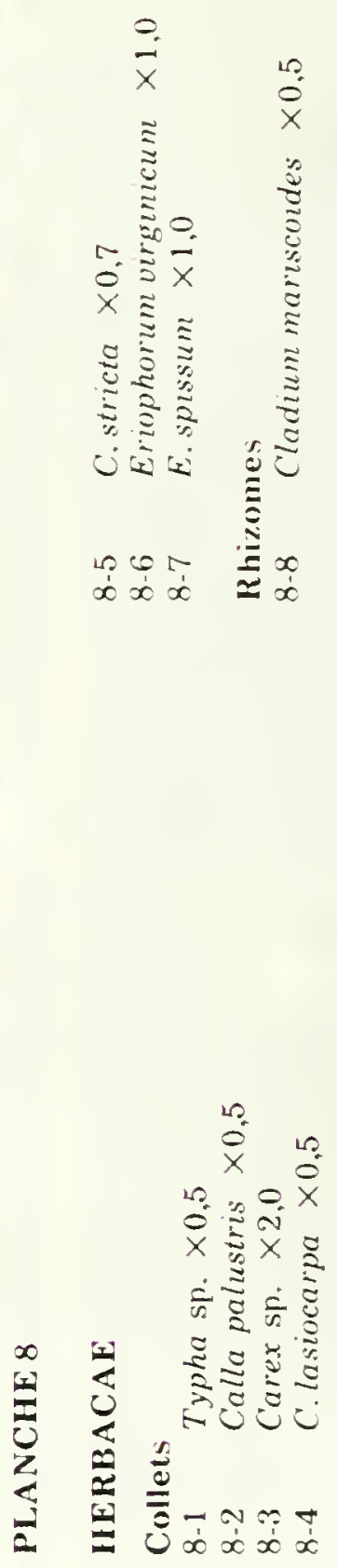


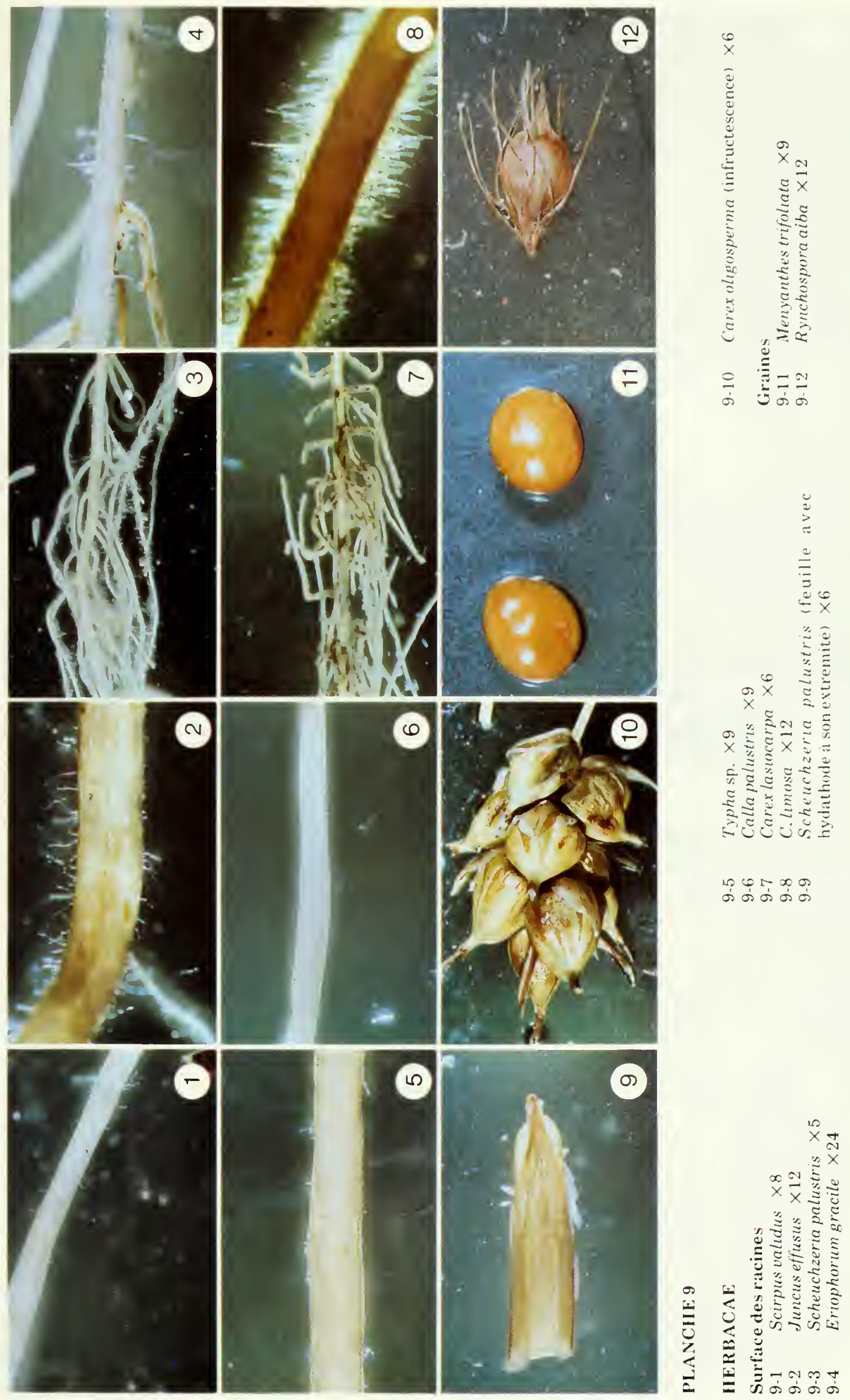




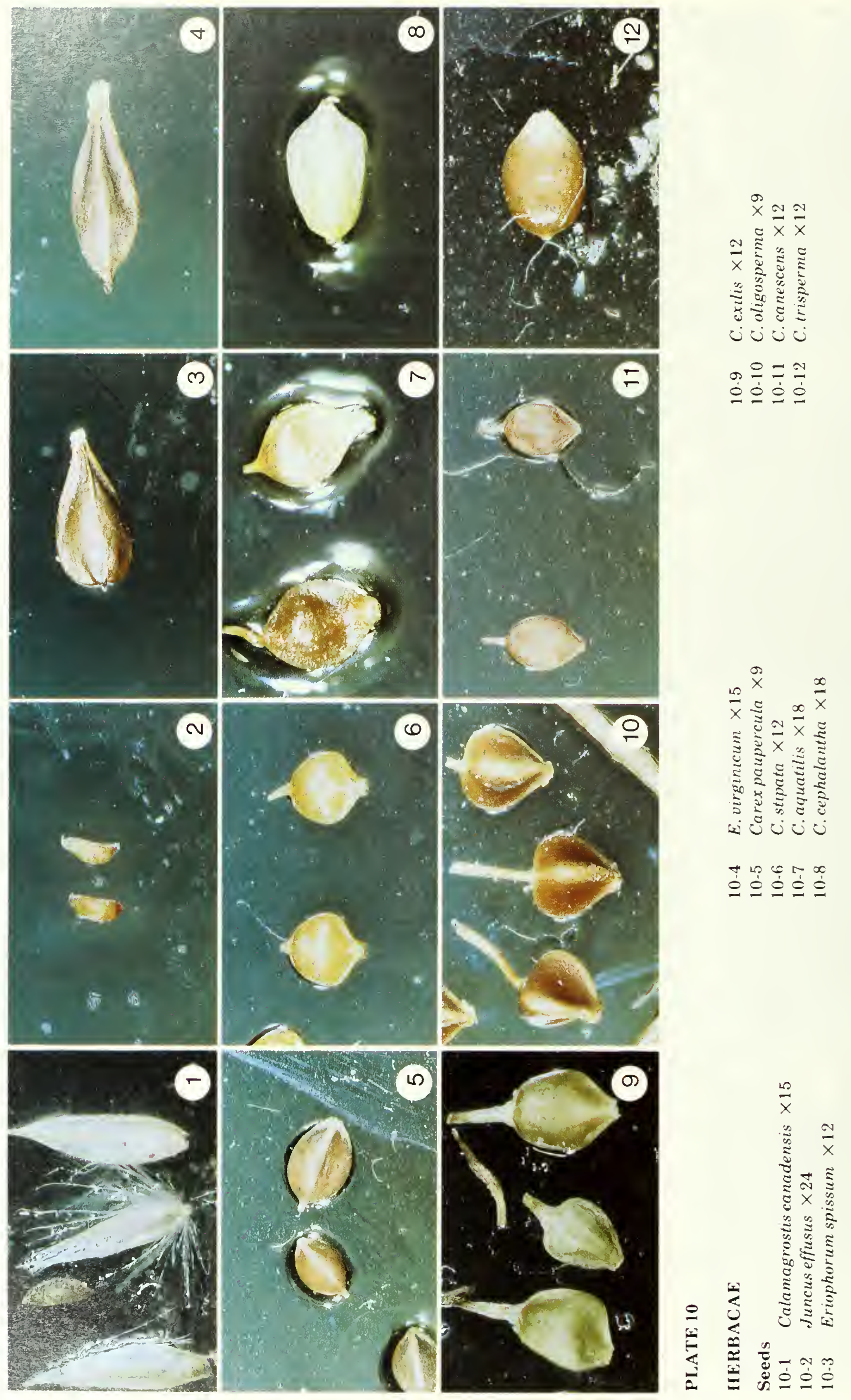




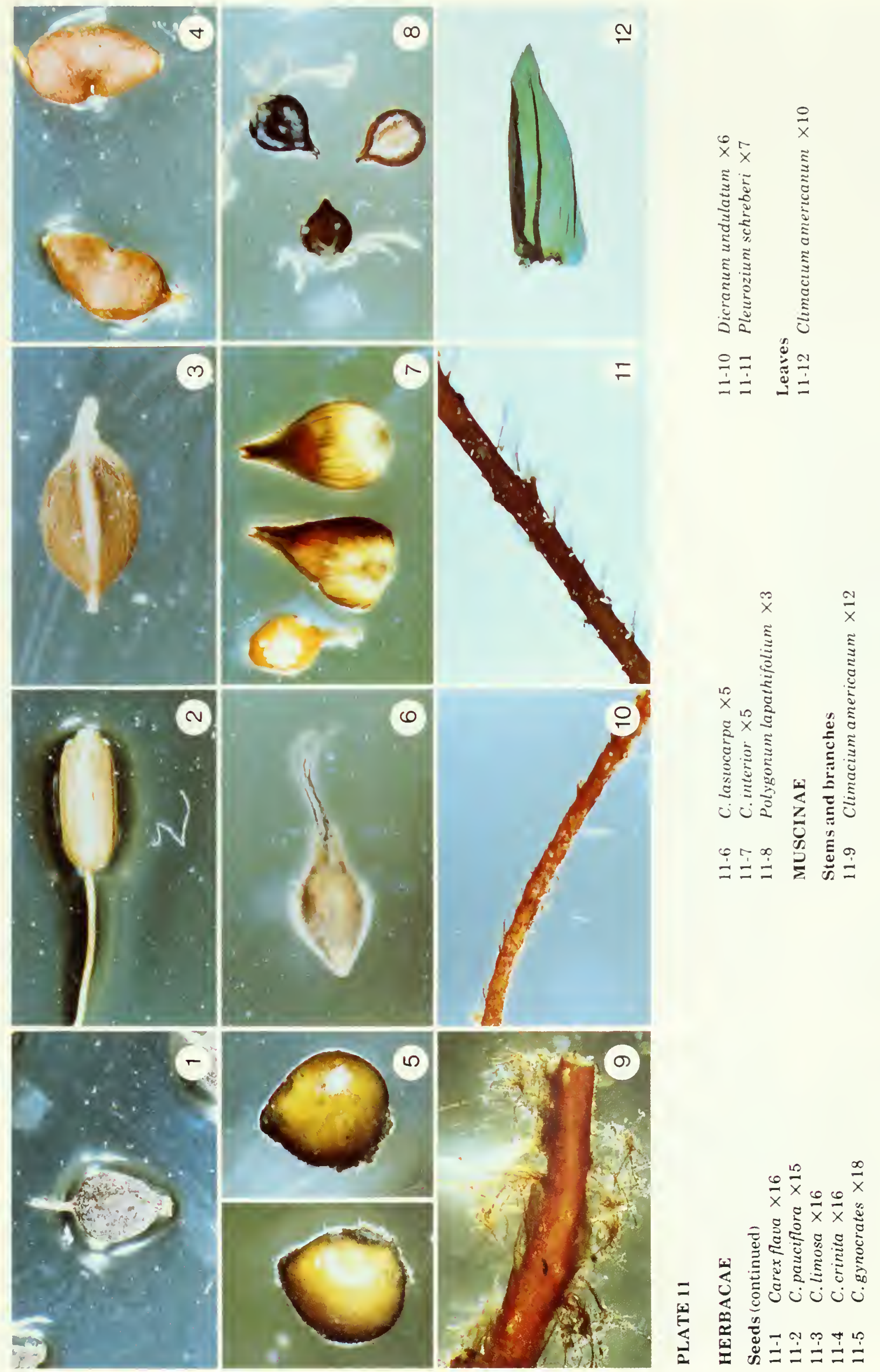




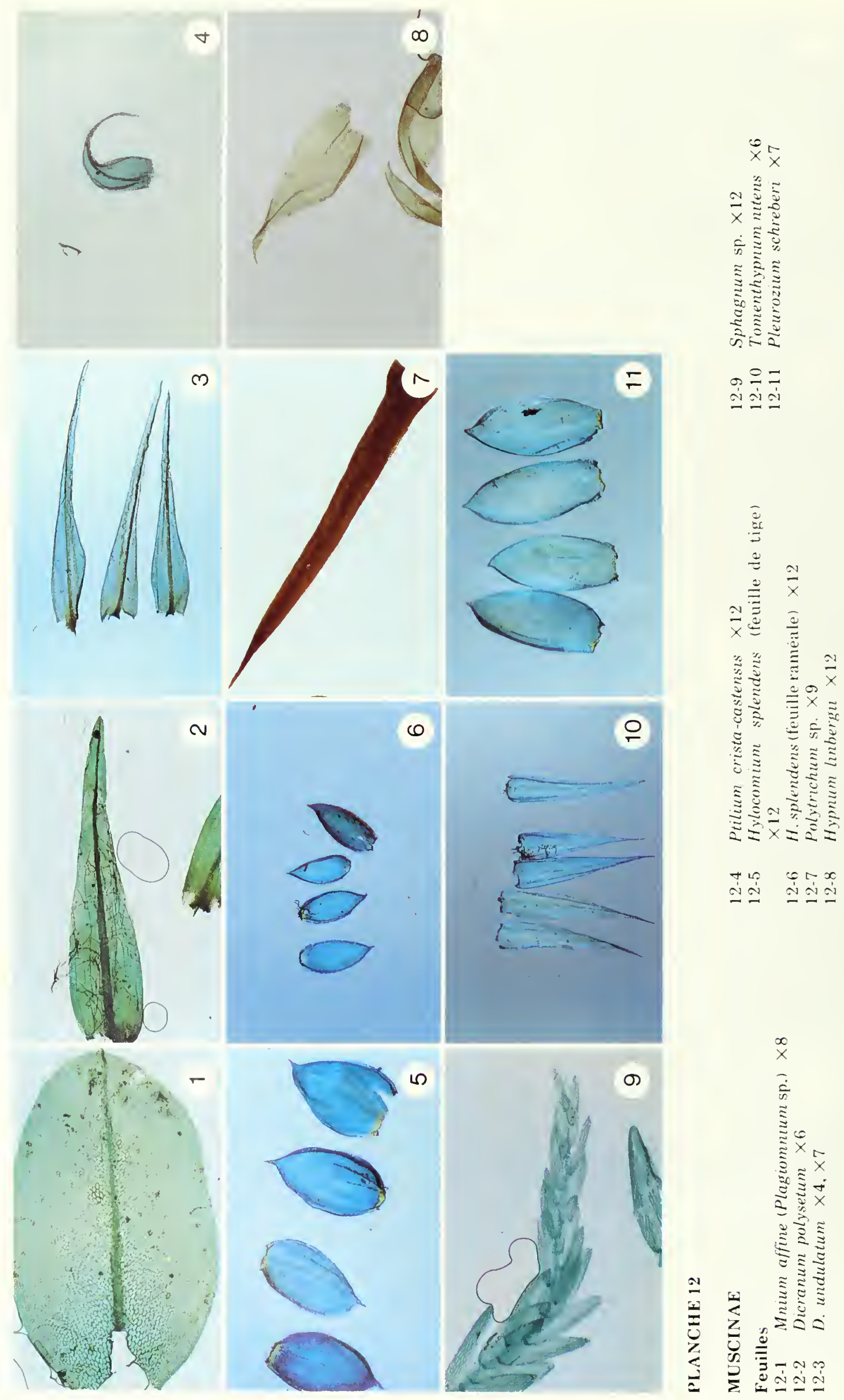




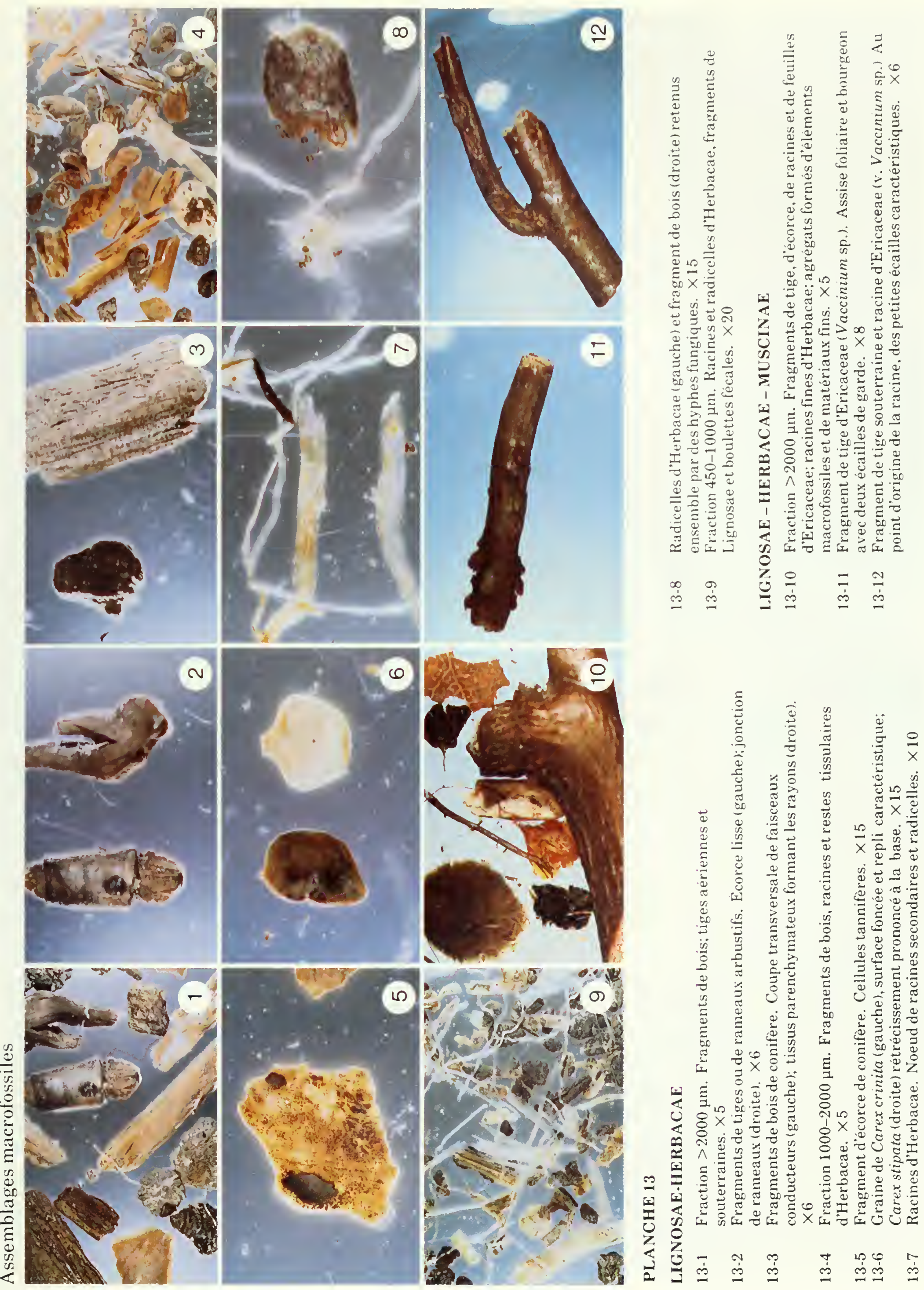



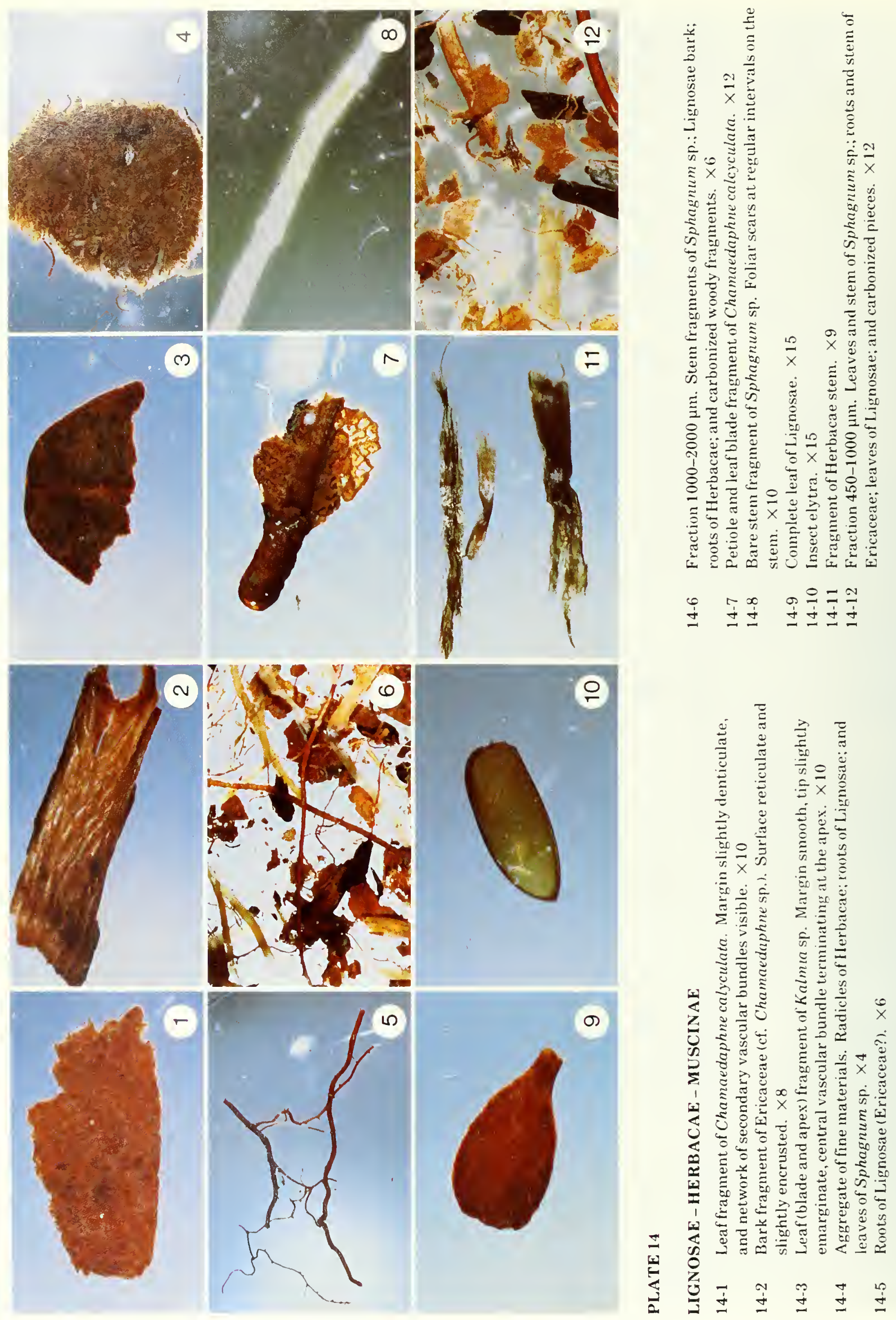


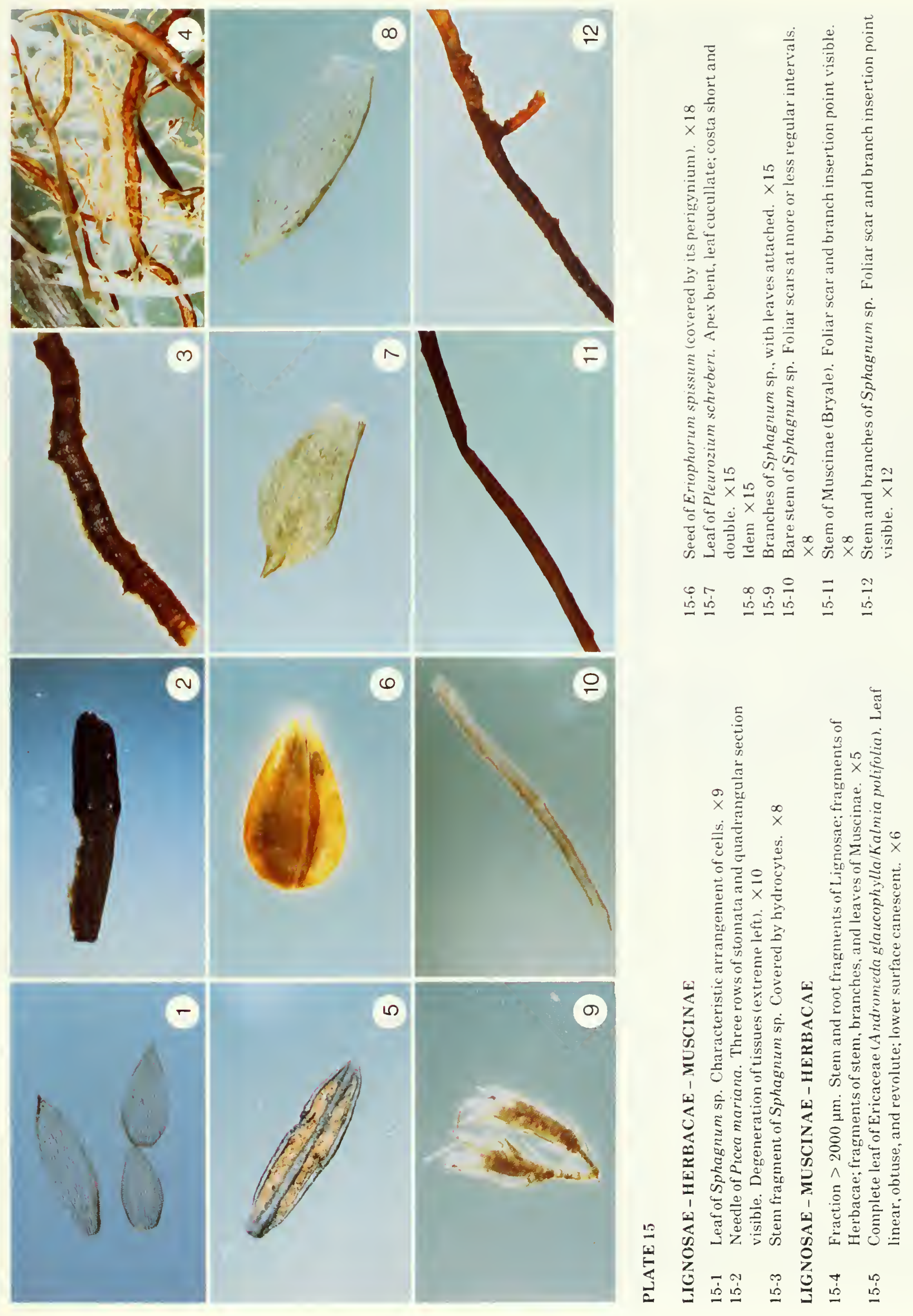




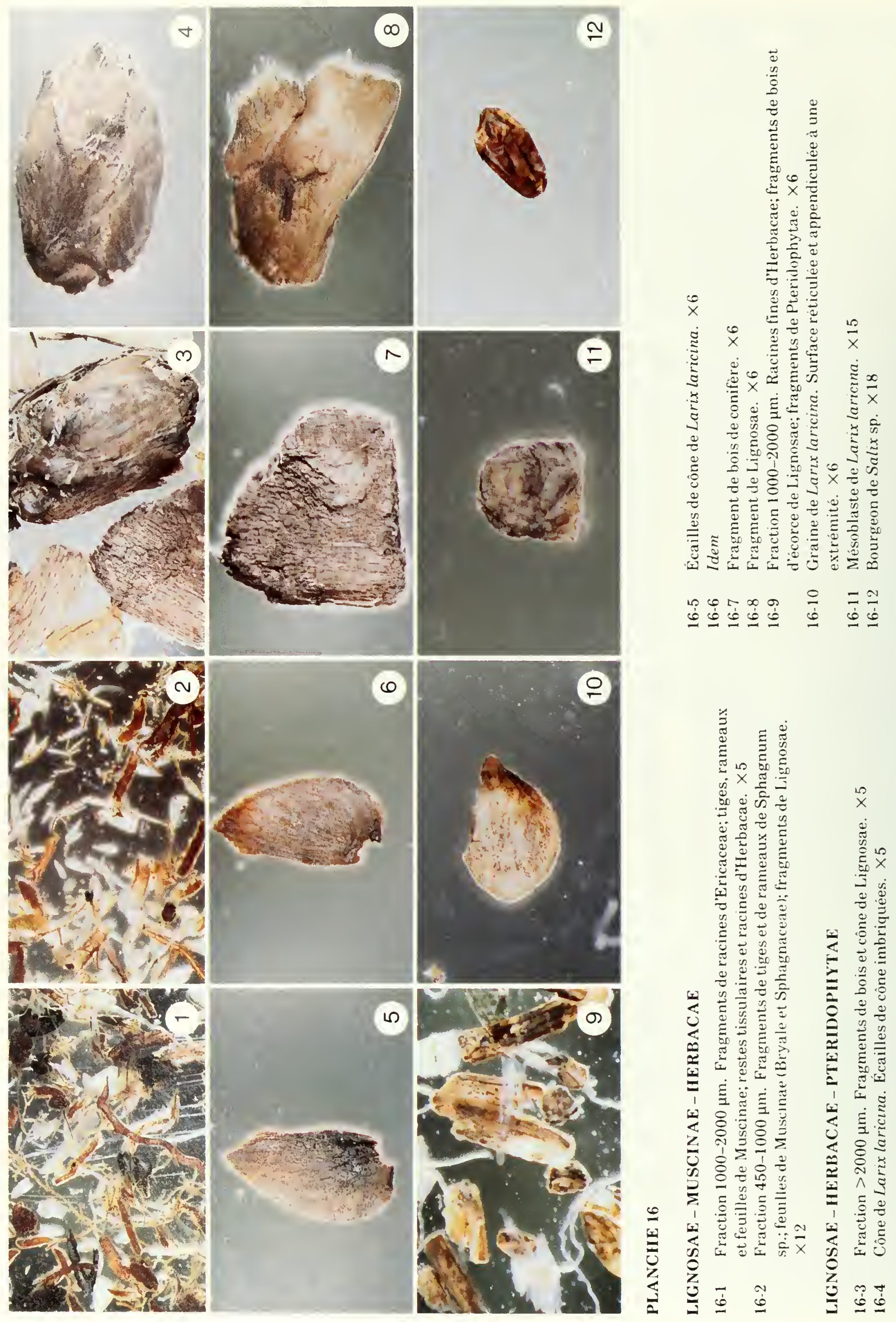



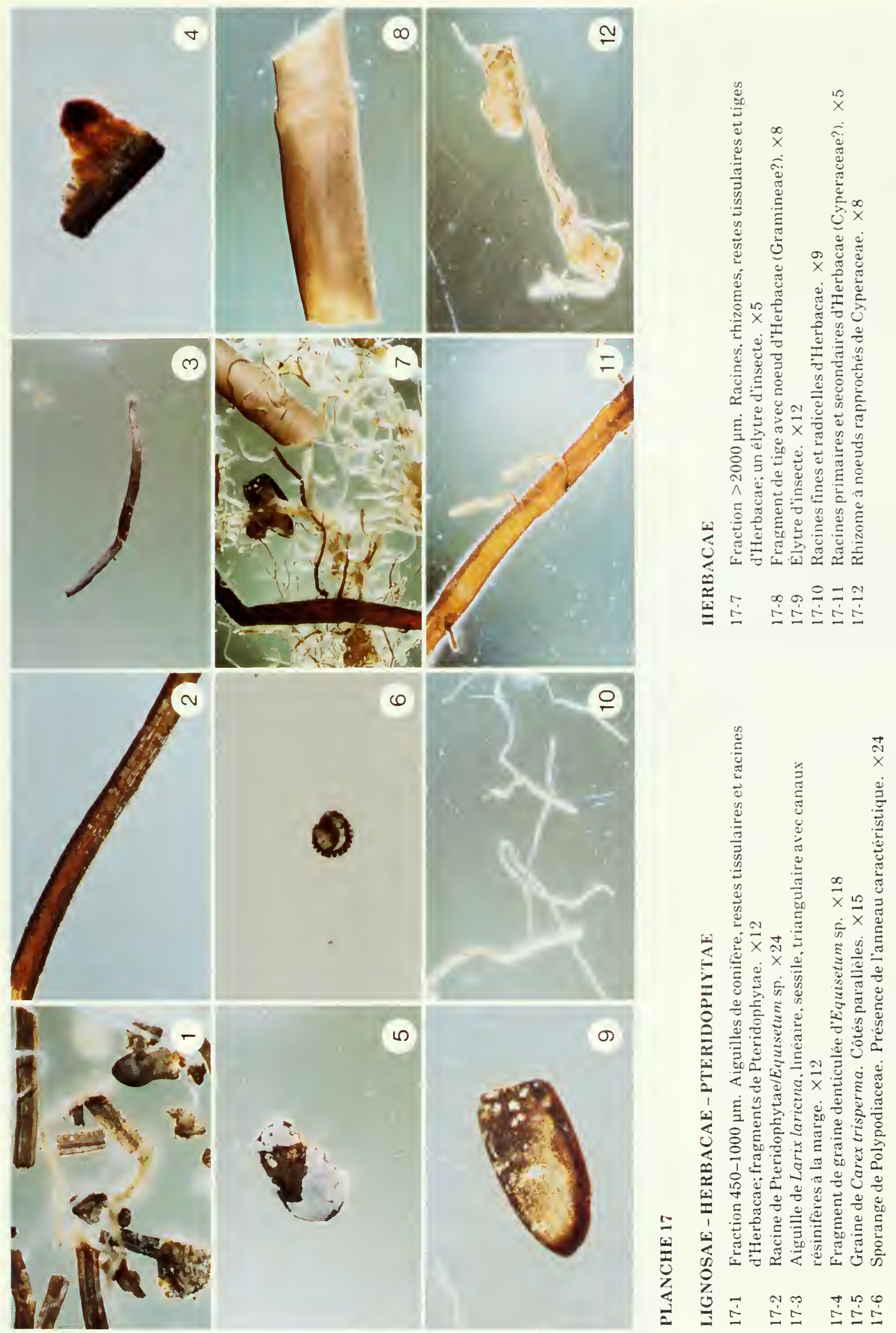

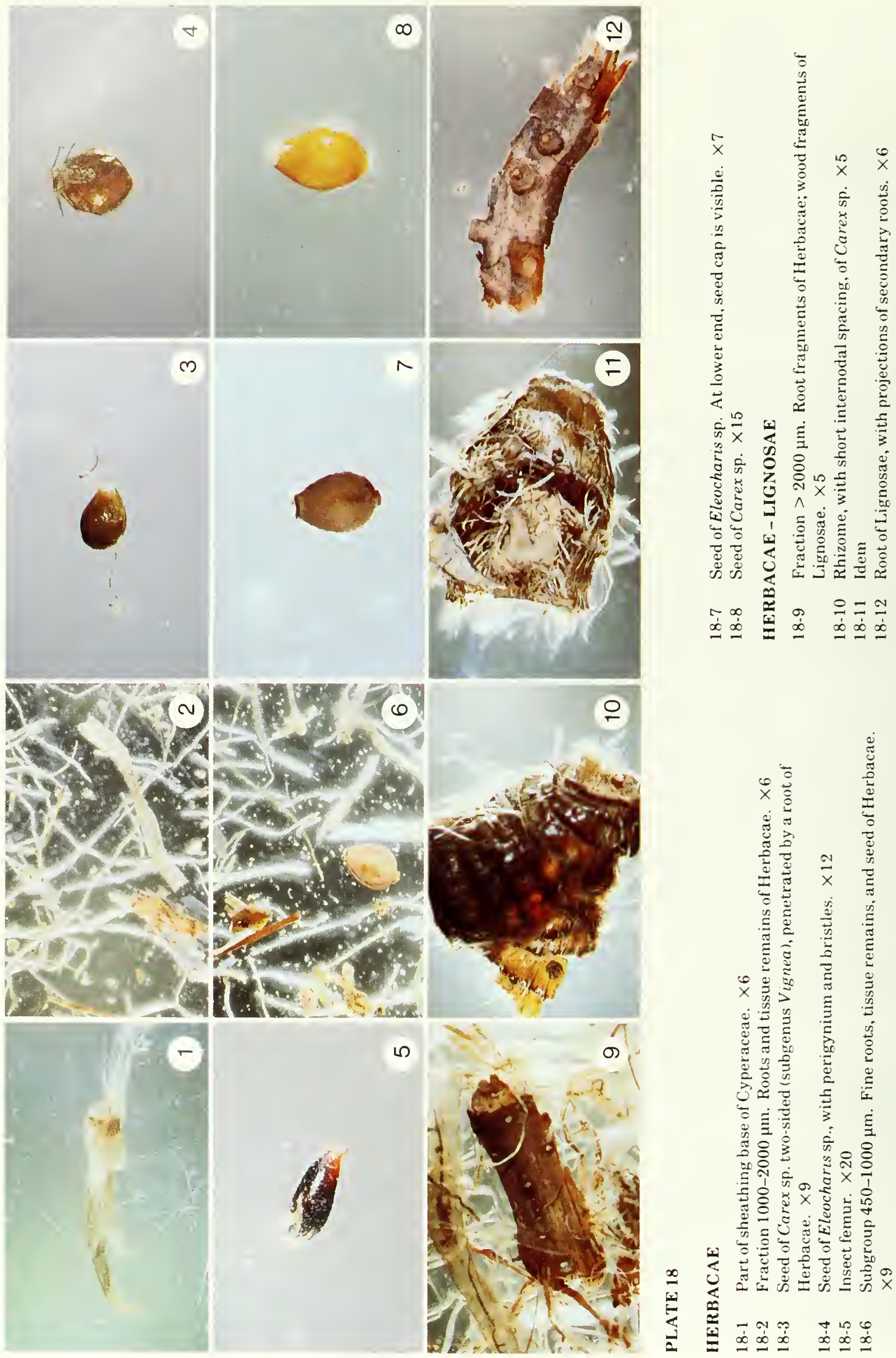

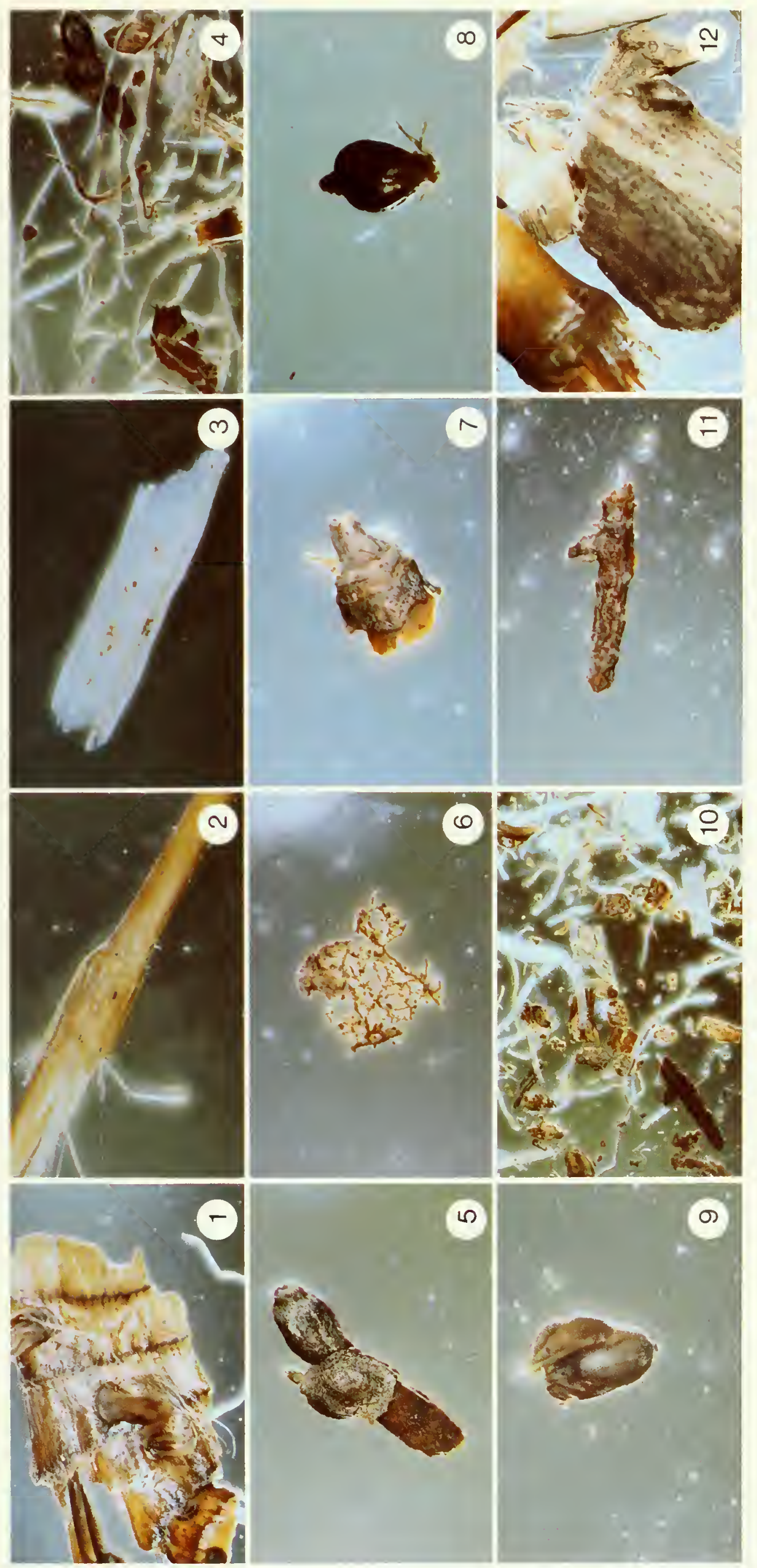

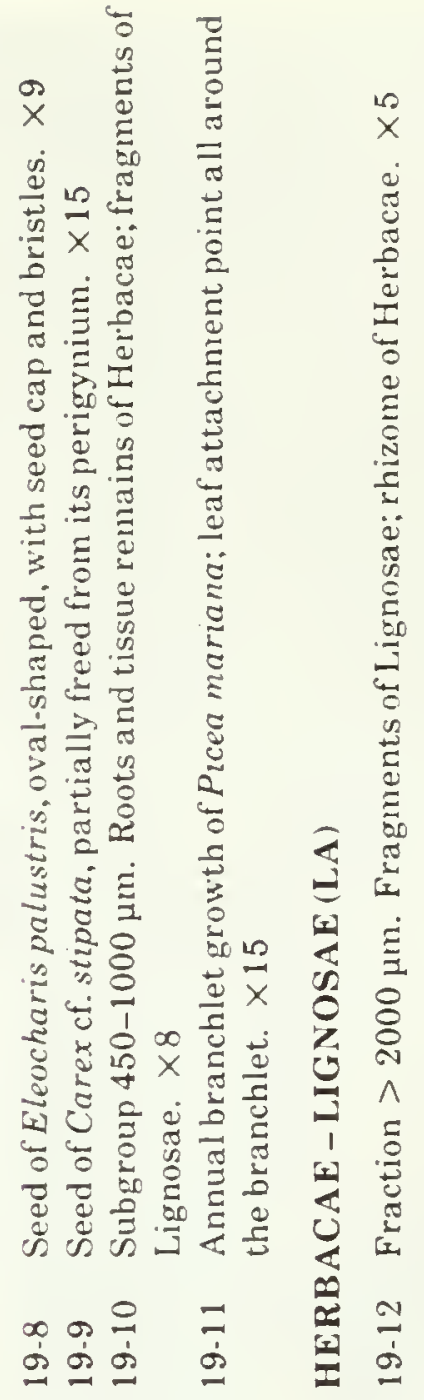

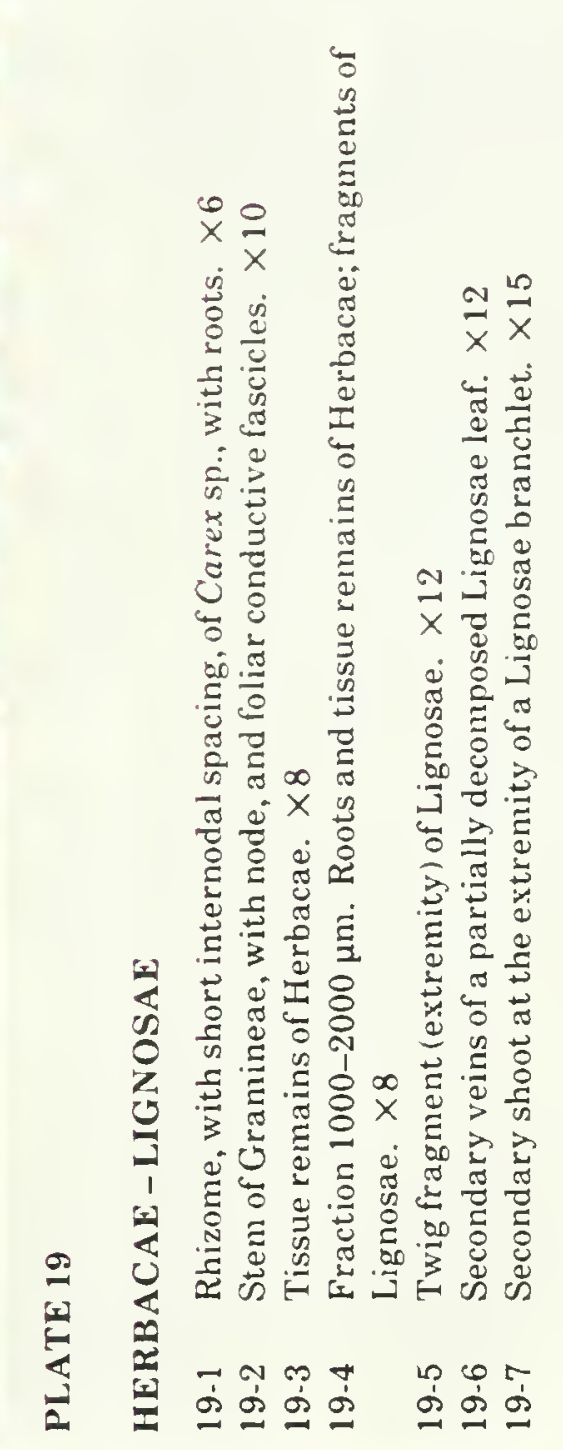




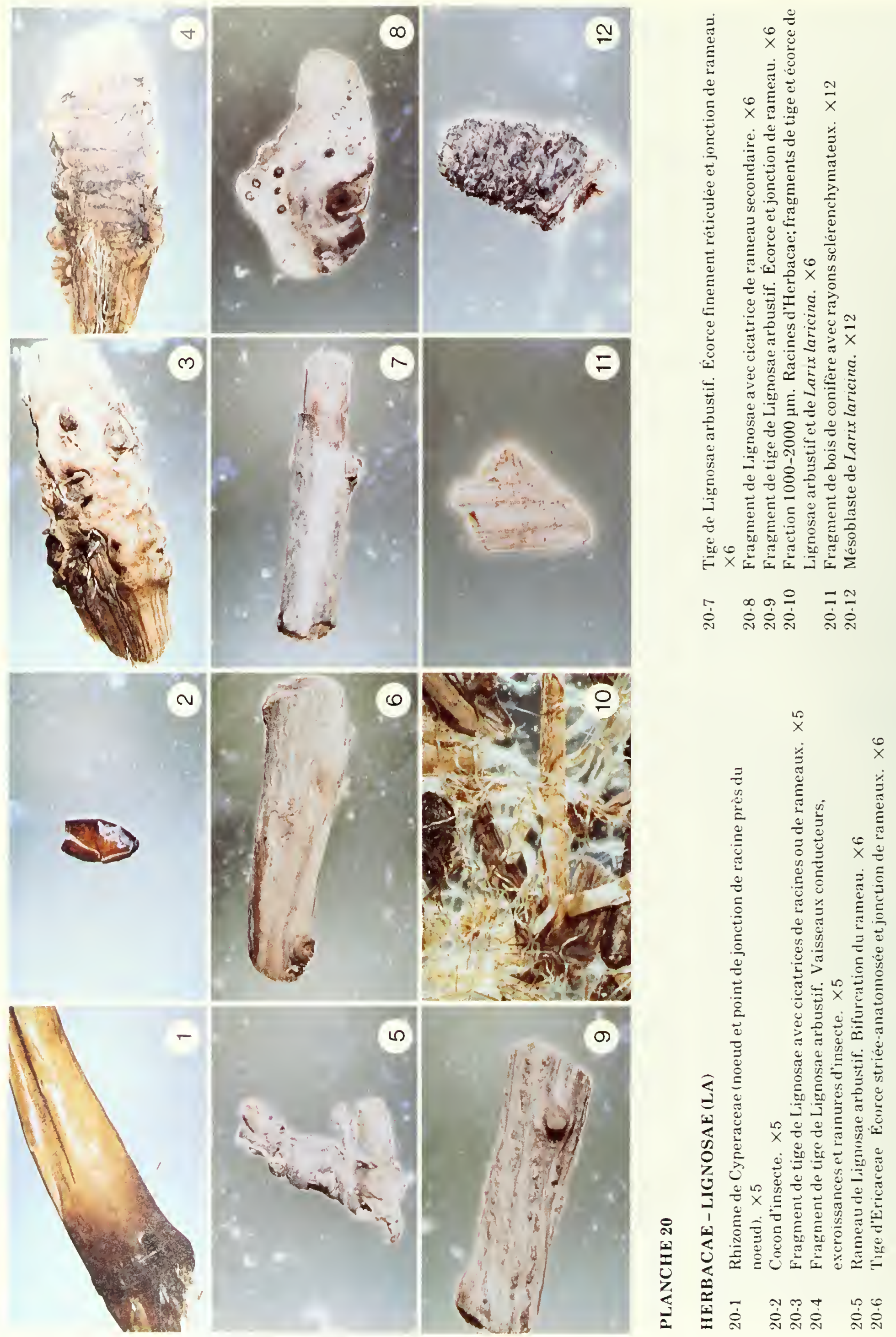



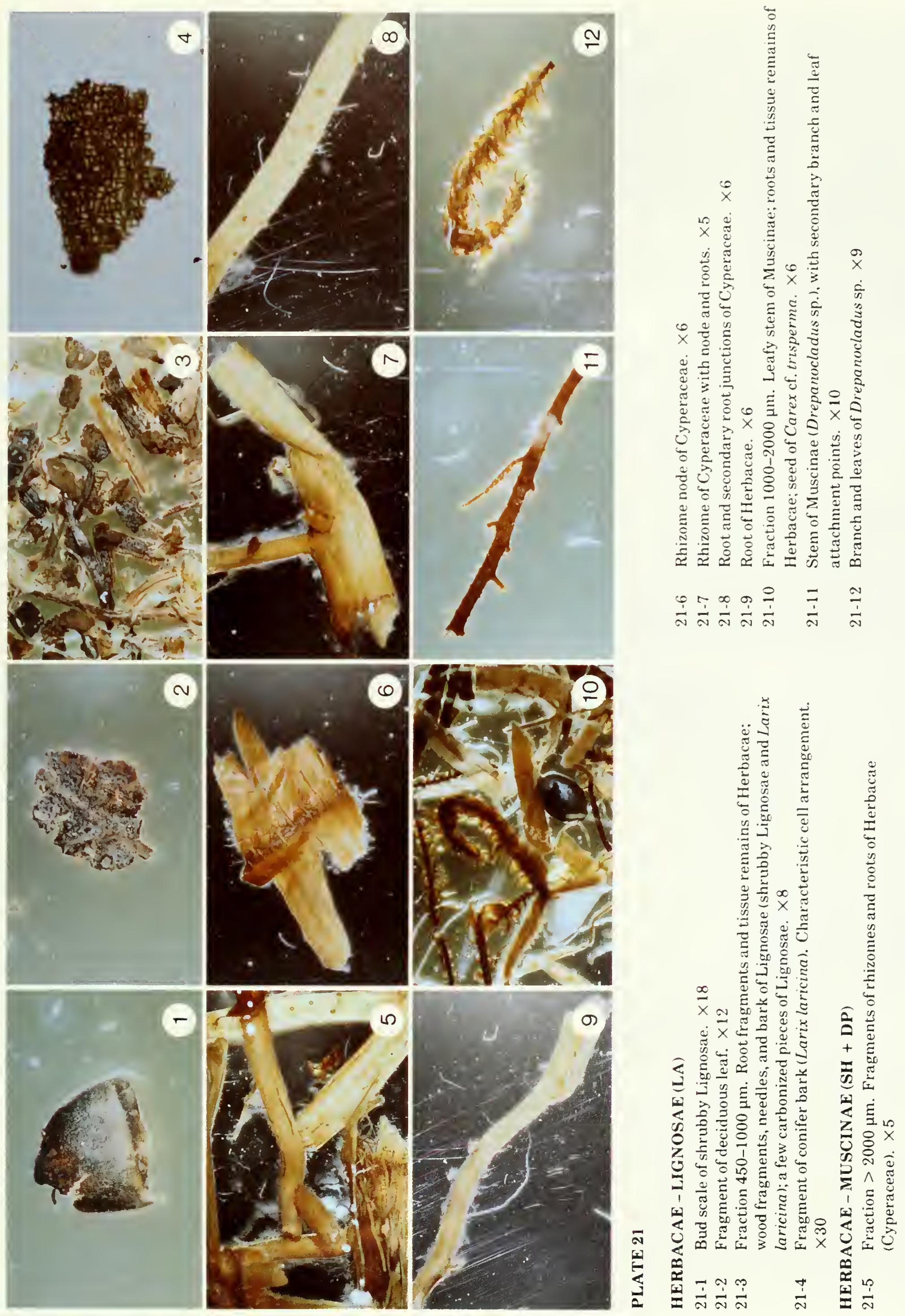


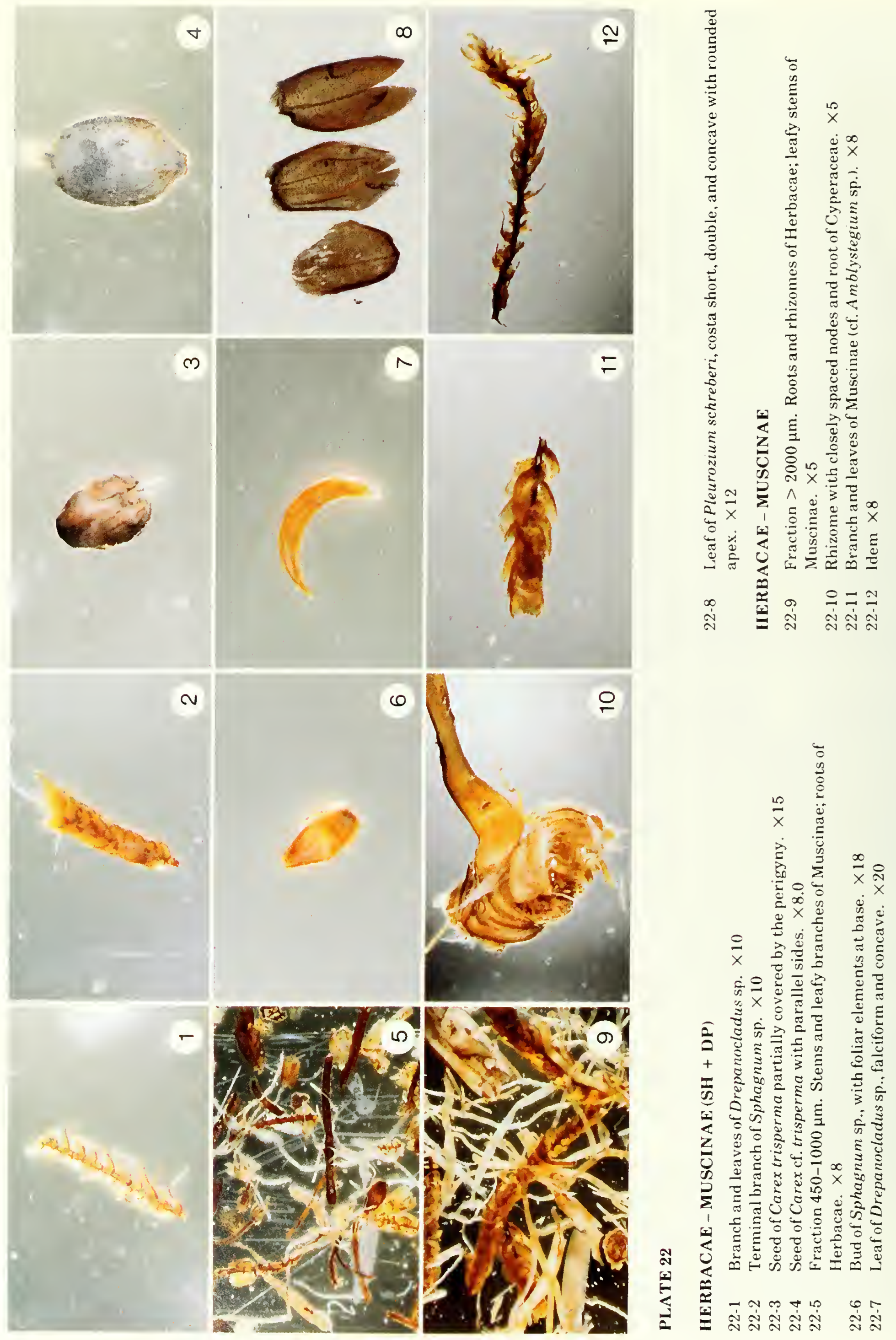



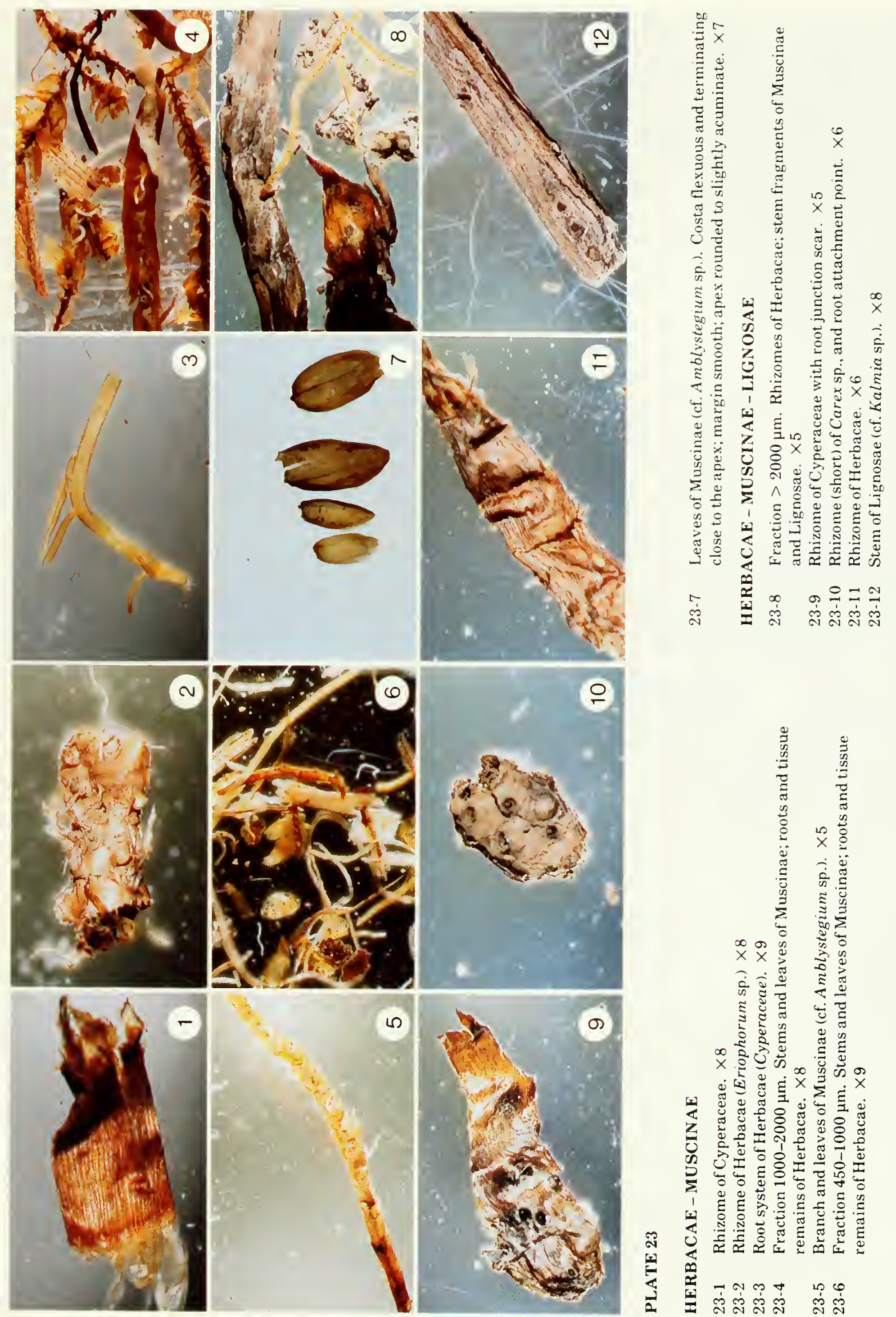

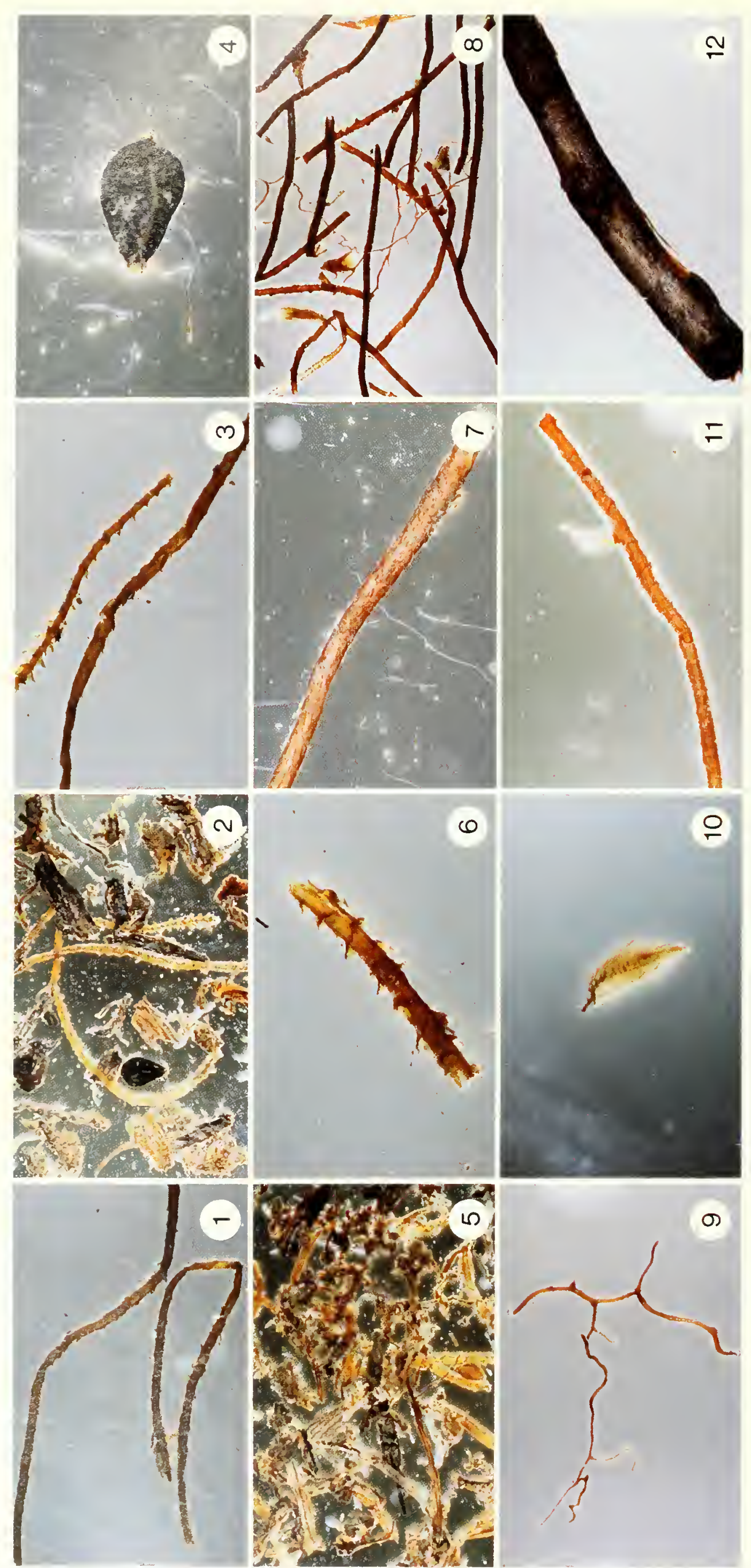

$\sigma$
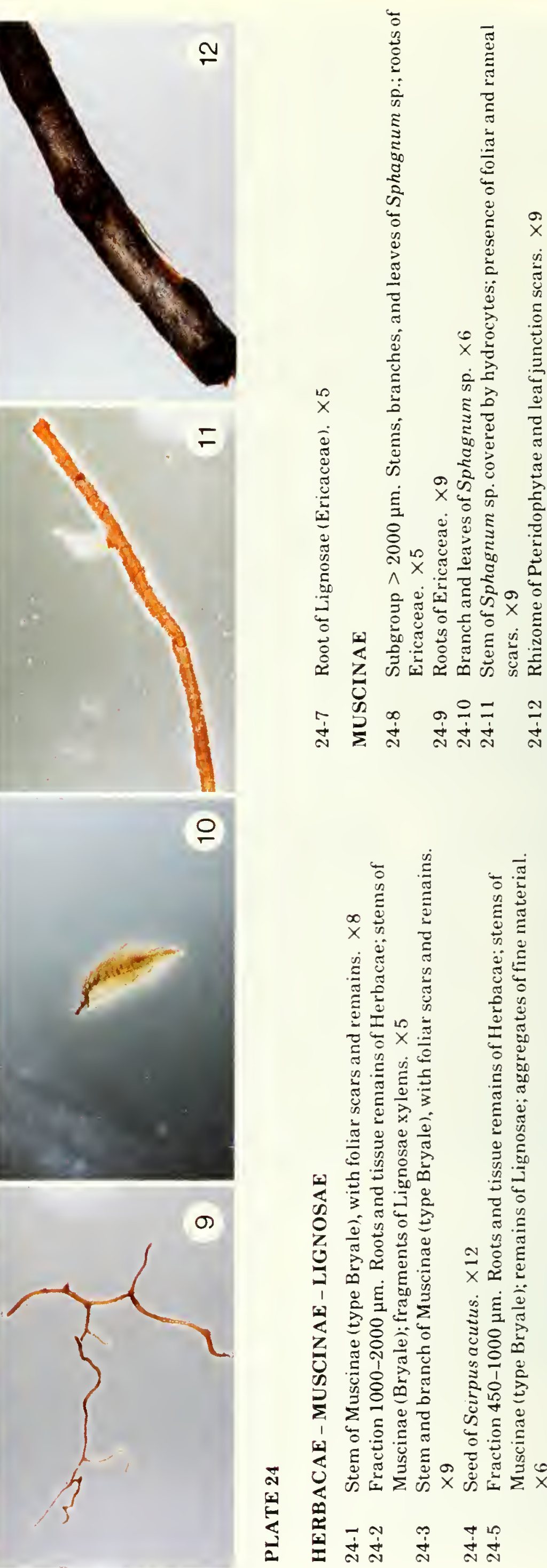


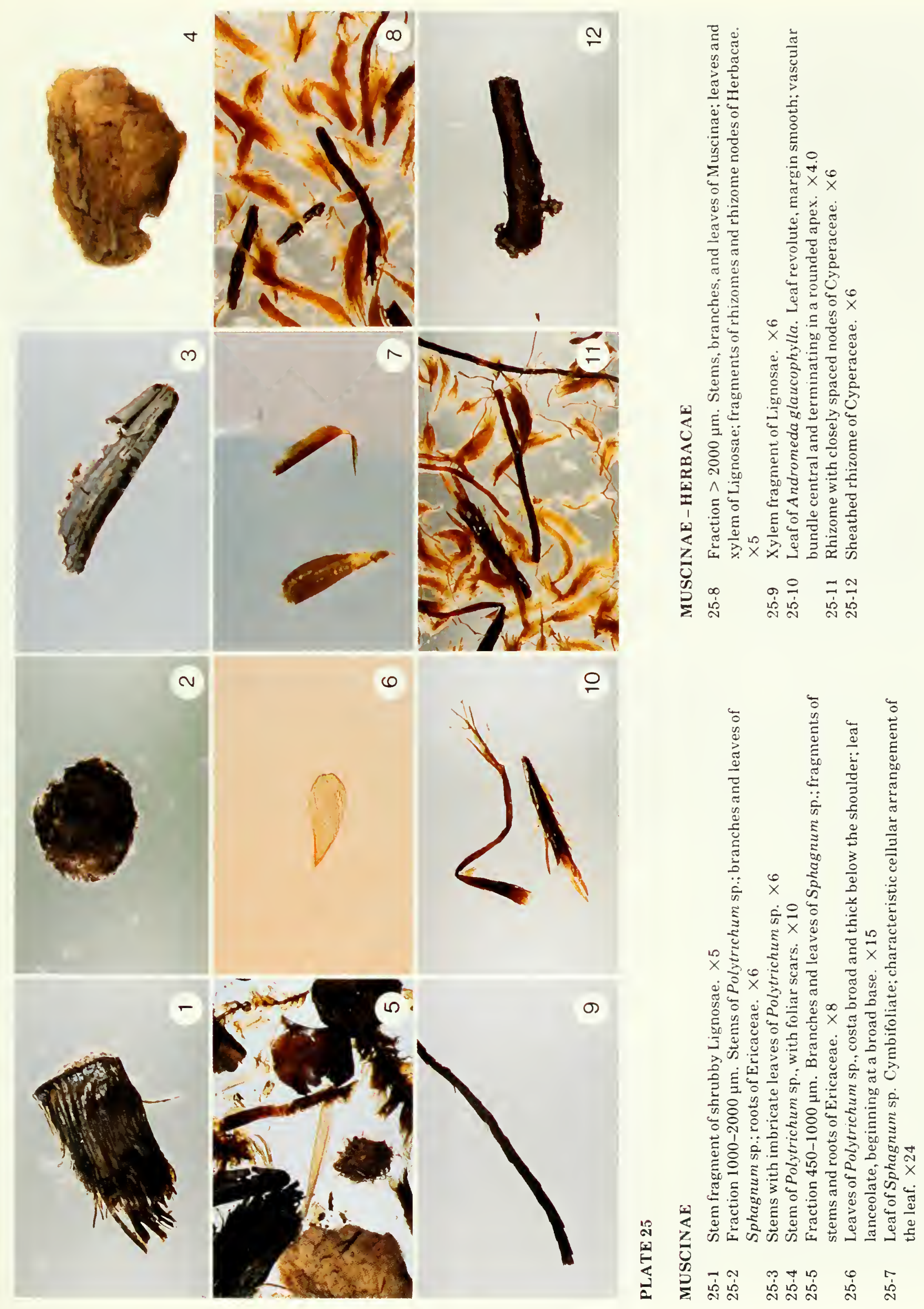



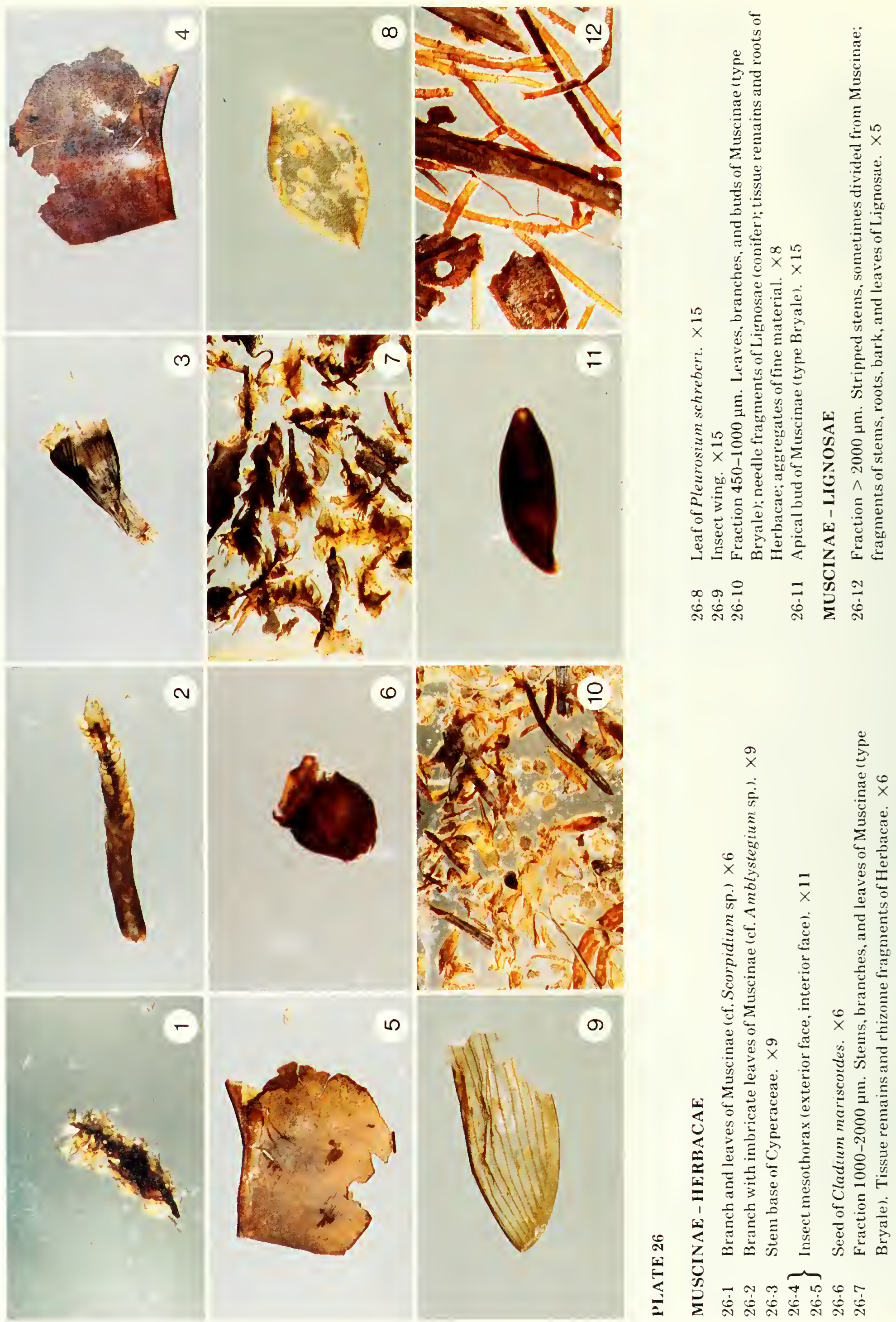

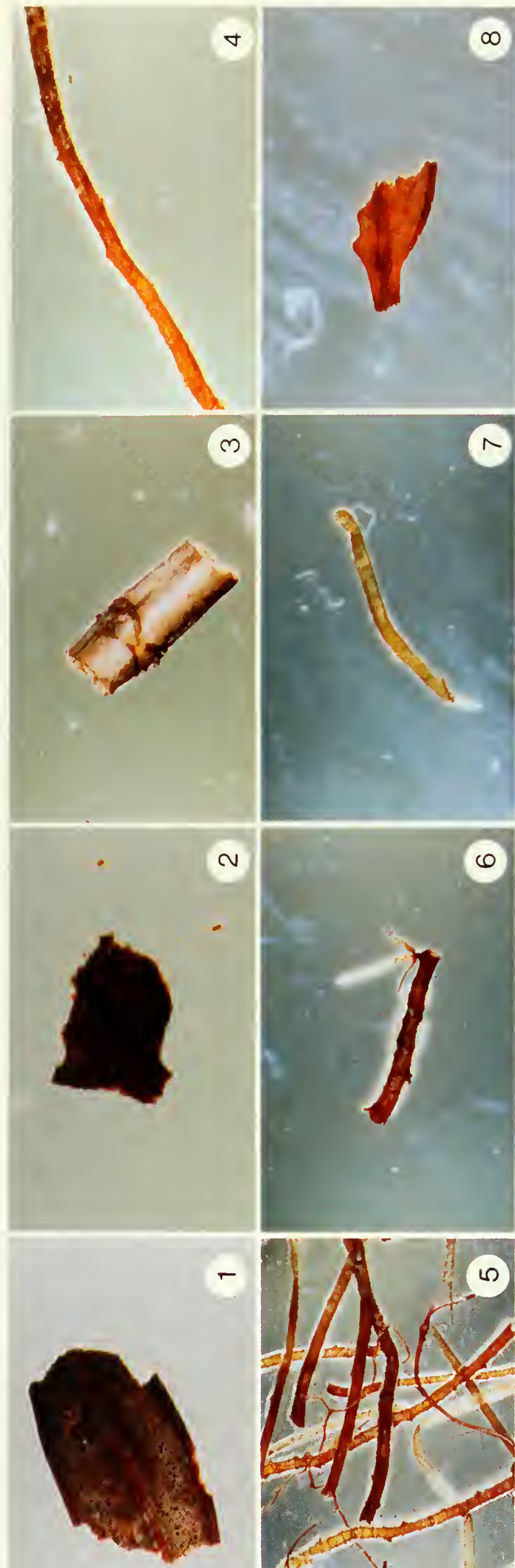
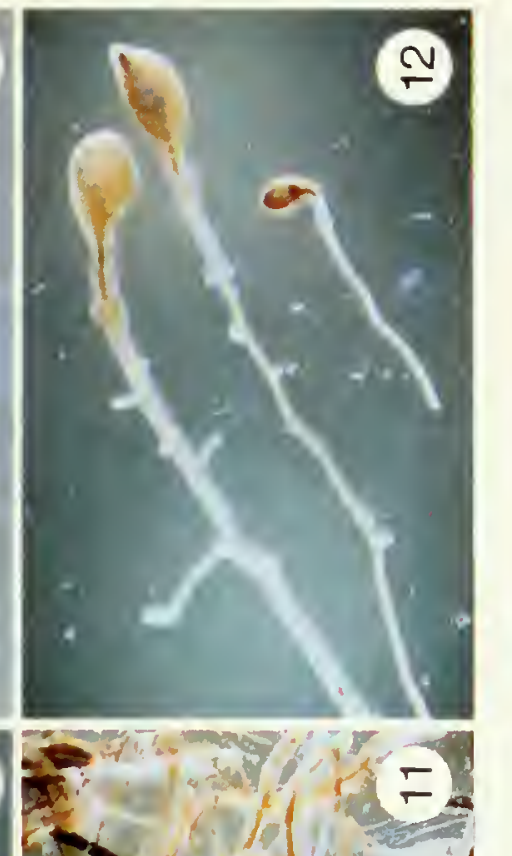

\section{(7.}

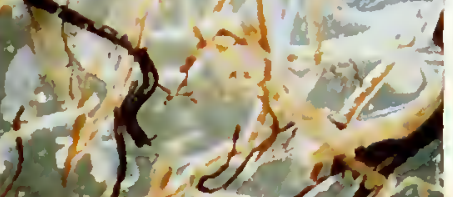

41
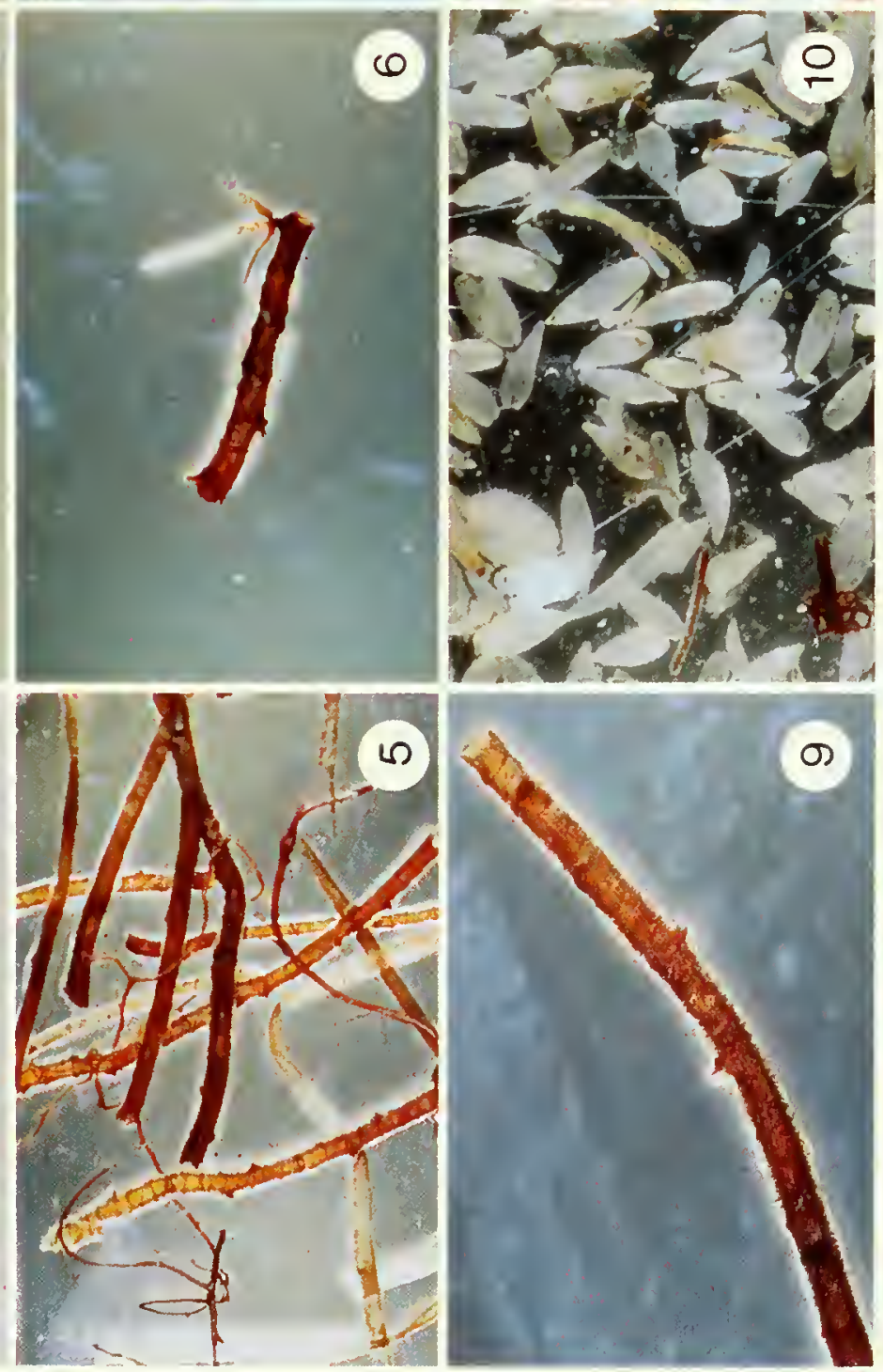

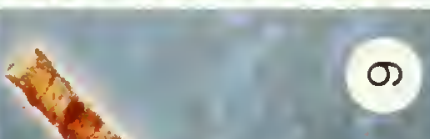

a)
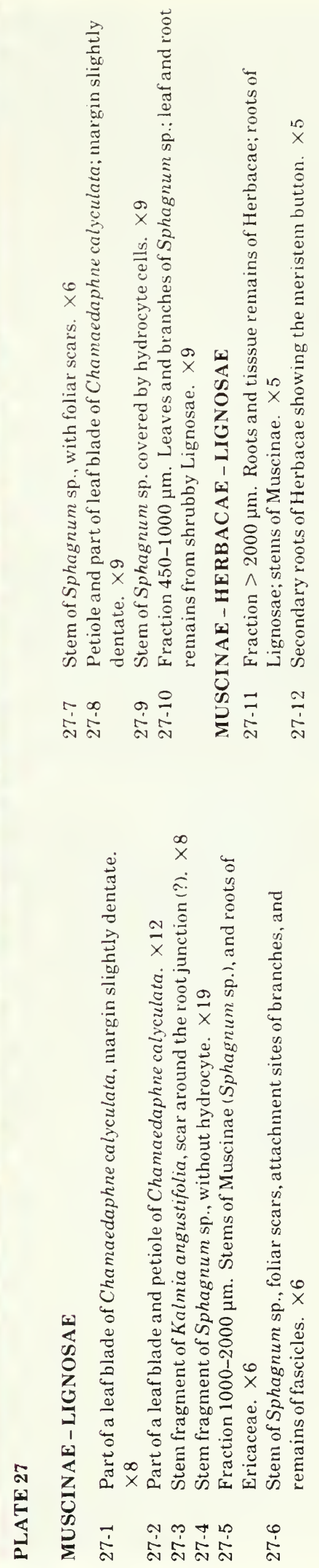

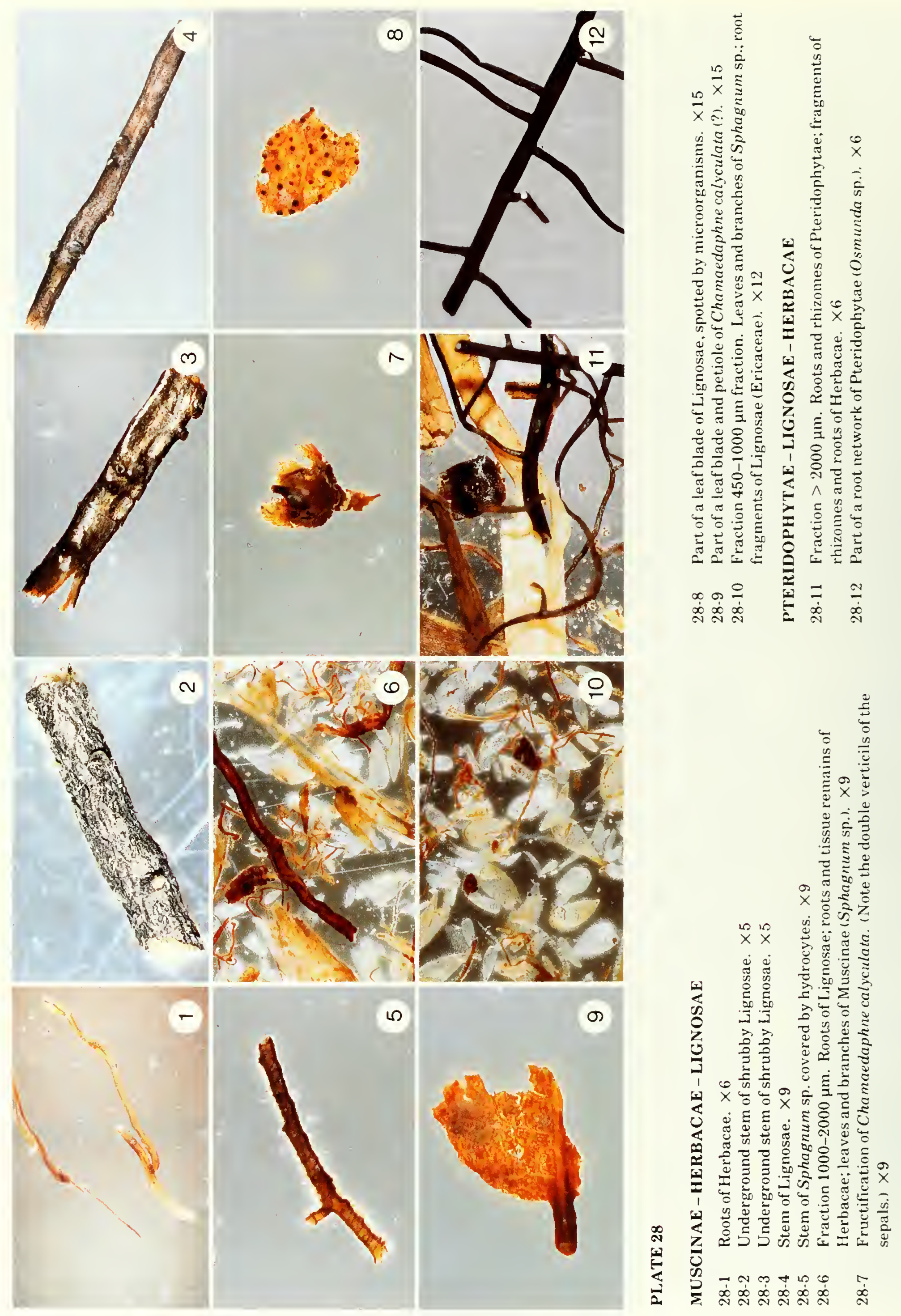

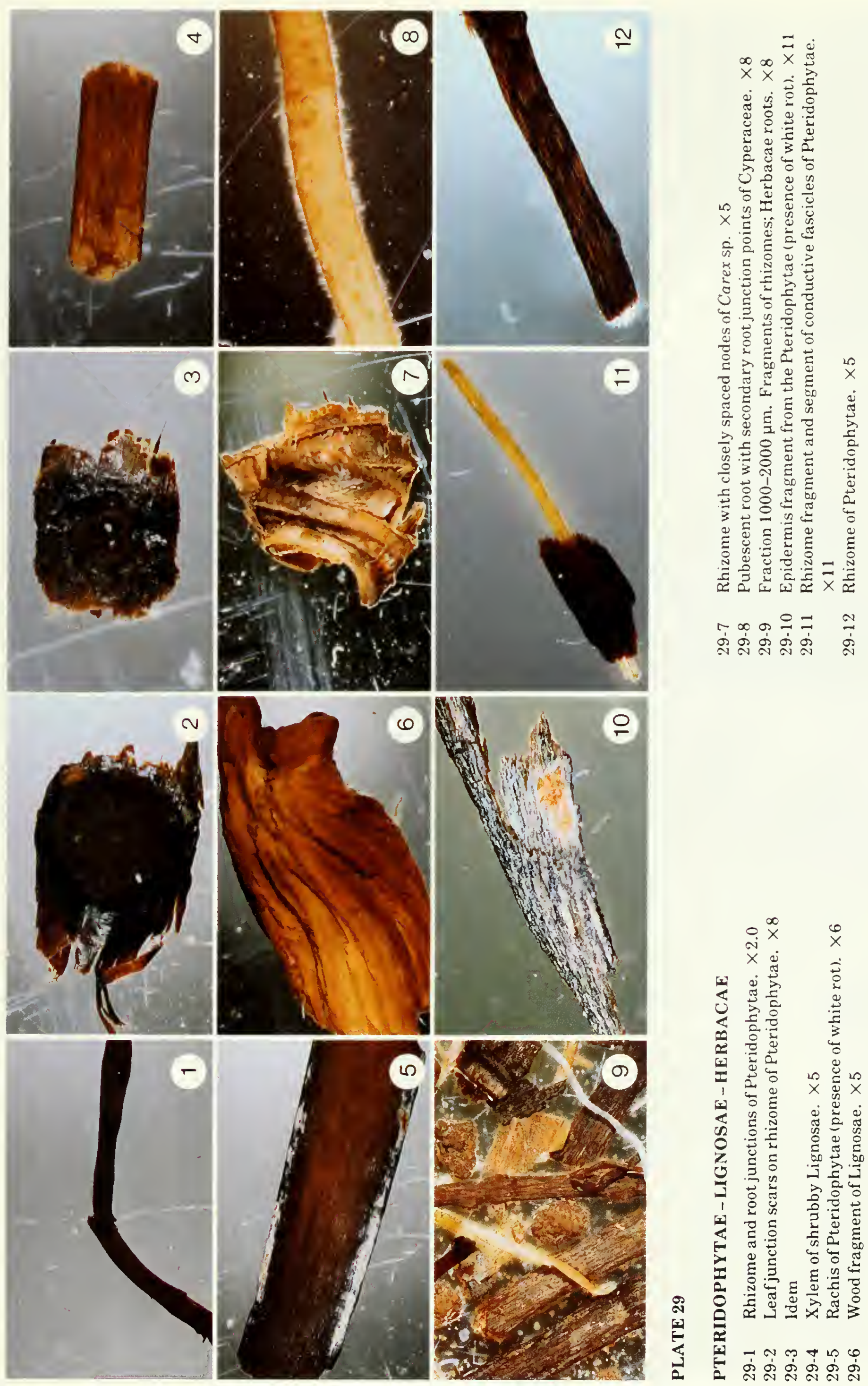

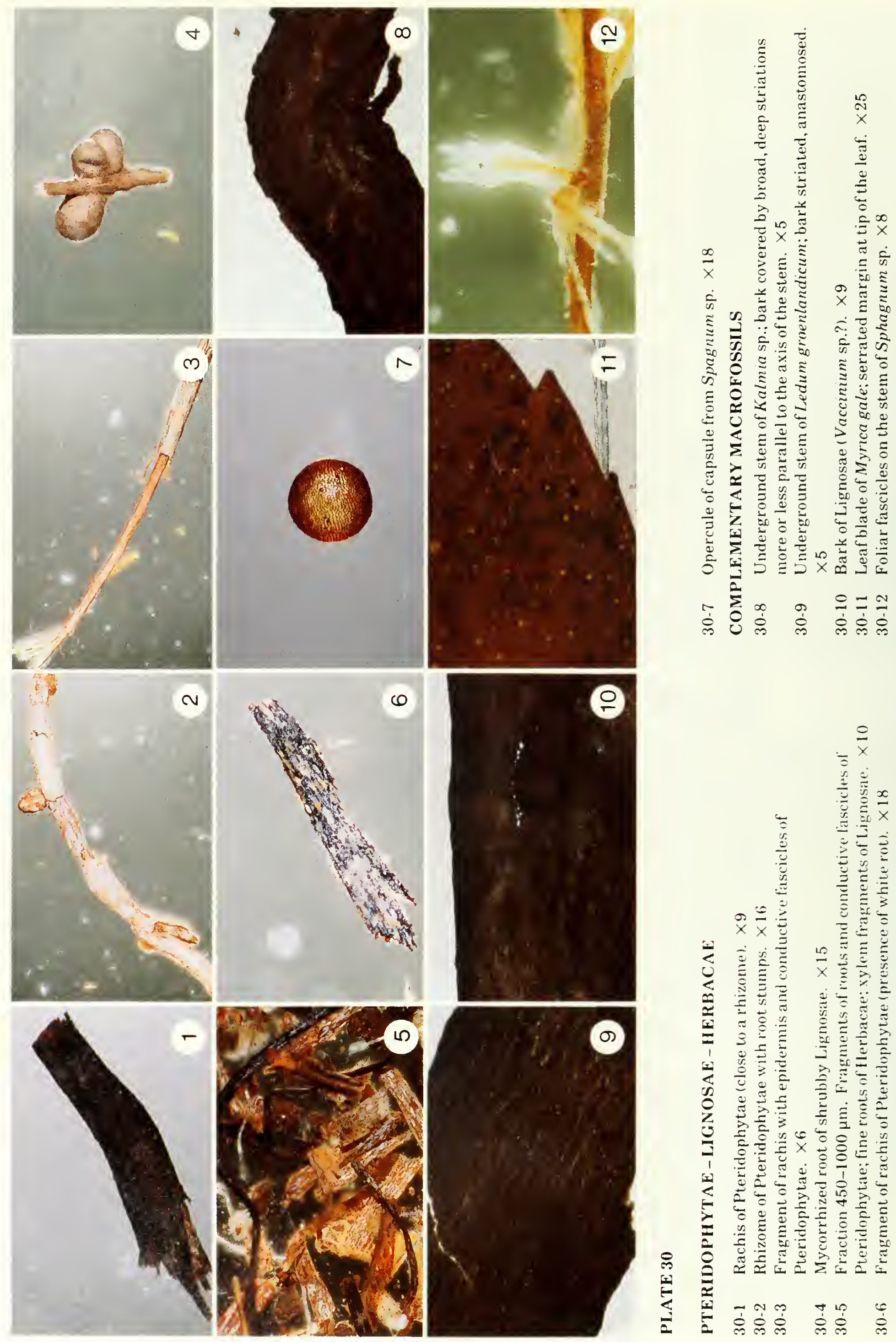


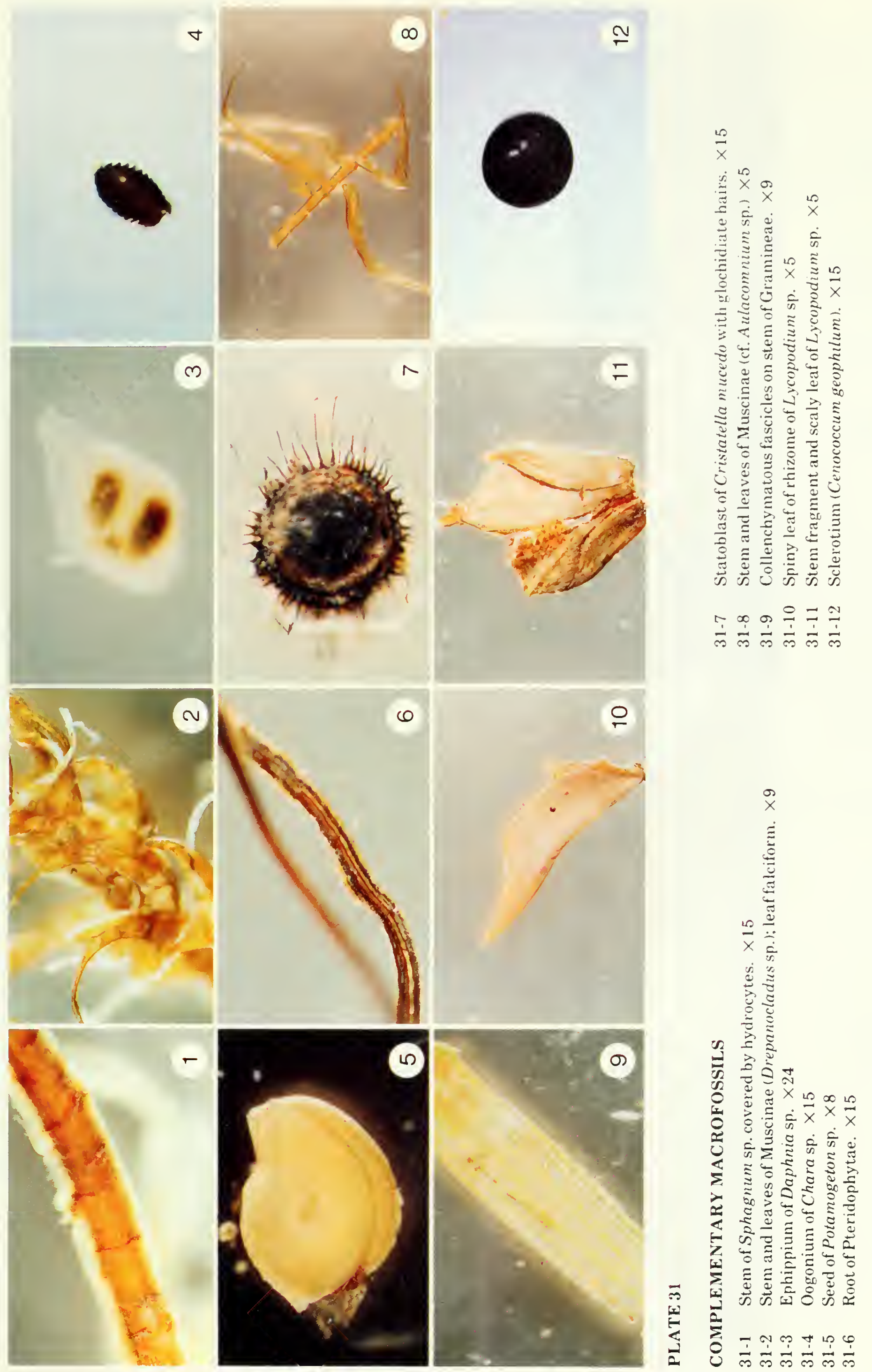



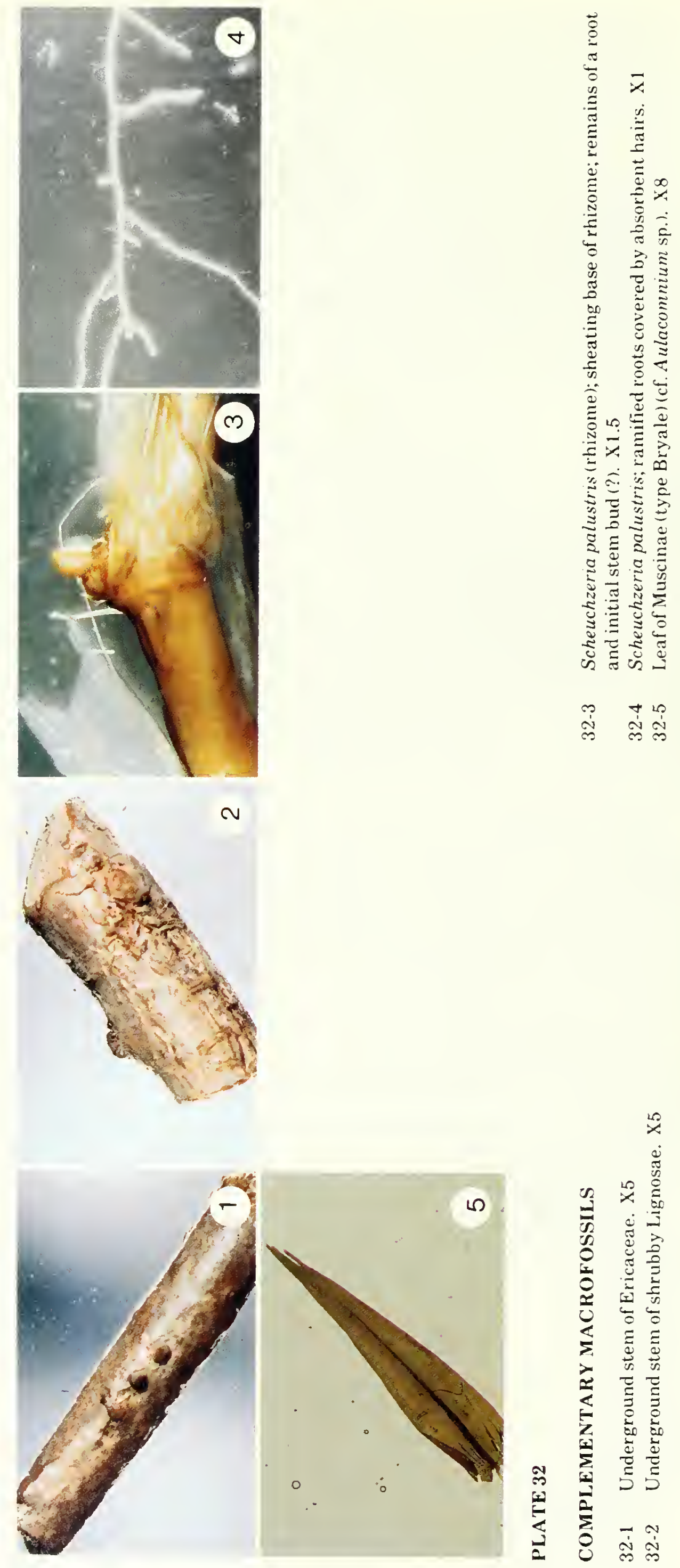


\section{LIS'T OF TAXA ILLUSTRATED IN THE GUIDE}

(The figures in lightface refer to the macrofossils; those in boldface refer to the reference elements.)

\begin{tabular}{|c|c|c|c|c|}
\hline & $\begin{array}{l}\text { Wlongated } \\
\text { structures }\end{array}$ & Leaves & Seeds & Others \\
\hline Abies balsamea & $4-1$ & & & \\
\hline Alnus rugosa & $3-11$ & & & \\
\hline Amblystegium (cf.) & $26-2$ & $23-7$ & & $\begin{array}{l}22-11,22-12 \\
23-5\end{array}$ \\
\hline Andromeda glaucophylla & $1-2,1-9$ & $\begin{array}{l}2-9,2-10 \\
25-10\end{array}$ & 6-6 & \\
\hline $\begin{array}{l}\text { A. glaucophylla } \\
\text { Kalmia polifolia }\end{array}$ & & $15-5$ & & \\
\hline Aulacomnium sp. & $31-8$ & $32-5$ & & \\
\hline Bryales & $15-11,24-1$ & & & $\begin{array}{l}24-3,24-6 \\
26-11\end{array}$ \\
\hline Calamagrostis canadensis & & & $10-1$ & \\
\hline Calla palustris & $8-2,9-6$ & & & \\
\hline Carexaquatilis & & & $10-7$ & \\
\hline C. canescens & & & $10-11$ & \\
\hline C. cephalantha & & & $10-8$ & \\
\hline C. crinita & & & $11-4,13-6$ & \\
\hline C. exilis & & & $10-9$ & \\
\hline C. flava & & & $11-1$ & \\
\hline C. gynocrates & & & $11-5$ & \\
\hline C. interior & & & 11.7 & \\
\hline C. lasiocarpa & $8-4,9-7$ & & $11-6$ & \\
\hline C. limosa & $9-8$ & & $11-3$ & \\
\hline C. oligosperma & & & $10-10$ & $9-10$ \\
\hline C. pauciflora & & & 11.2 & \\
\hline C. paupercula & & & $10-5$ & \\
\hline Carex sp. & $\begin{array}{l}8-3,18-10 \\
18-11,19-1 \\
29-7\end{array}$ & & $18-3,18-8$ & $23-10$ \\
\hline C. stipata & & & $\begin{array}{l}10-6,13-6 \\
19-9\end{array}$ & \\
\hline C. stricta & $8-5$ & & & \\
\hline C. trisperma & & & $\begin{array}{l}10-12,17-5 \\
22-3\end{array}$ & \\
\hline Carex cf. trisperma & & & $22-4$ & \\
\hline Cenococcum geophilum & & & & $31-12$ \\
\hline \multirow[t]{2}{*}{ Chamaedaphne calyculata } & $\begin{array}{l}1-1,1-8 \\
3-9\end{array}$ & $\begin{array}{l}2-7,2-8,14-1 \\
14-7,27-1\end{array}$ & $6-2$ & $\begin{array}{l}4-11,5-2 \\
27-8,28-7 \\
28-9\end{array}$ \\
\hline & & $27-2$ & & \\
\hline Chamaedaphnesp. & & & & $14-2$ \\
\hline Chara sp. & & & & $31-4$ \\
\hline Cladium mariscoides & $\begin{array}{l}7 \cdot 7,8 \cdot 8 \\
8 \cdot 11\end{array}$ & & $26-6$ & \\
\hline Climacium americanum & $11-9$ & $11 \cdot 12$ & & \\
\hline $\begin{array}{l}\text { Conifer } \\
\text { Cristatella mucedo }\end{array}$ & $13-3,16-7$ & & & $\begin{array}{l}13-5,20-11 \\
31-7\end{array}$ \\
\hline
\end{tabular}




\begin{tabular}{|c|c|c|c|c|}
\hline & $\begin{array}{l}\text { Elongated } \\
\text { structures }\end{array}$ & Leaves & Seeds & Others \\
\hline Cyperaceae & $\begin{array}{l}17-12,18-1 \\
21-6,21-7 \\
21-8,23-1 \\
23-3,25-11\end{array}$ & & & $\begin{array}{l}20-1,22-10 \\
23-9,23-10 \\
23-11,25-12 \\
26-3,29-8\end{array}$ \\
\hline $\begin{array}{l}\text { Daphniasp. } \\
\text { Deciduous }\end{array}$ & & & & $\begin{array}{l}31-3 \\
21-2\end{array}$ \\
\hline Dicranum polysetum & & $12-2$ & & \\
\hline D. undulatum & $11-10$ & $12-3$ & & \\
\hline $\begin{array}{l}\text { Drepanocladus sp. } \\
\text { Eleocharis elliptica }\end{array}$ & $\begin{array}{l}21-11,21-12 \\
7-8,8-12\end{array}$ & $22-7$ & & $31-2$ \\
\hline E. palustris & & & $19-8$ & \\
\hline Eleocharis sp. & & & $18-4,18-7$ & \\
\hline Equisetum sp. & & & & $17-4$ \\
\hline Ericaceae & $\begin{array}{l}14-5,20-6,24-7 \\
24-9,32-1\end{array}$ & & & \\
\hline Eriophorum gracile & $7-12,9-4$ & & & \\
\hline Eriophorum sp. & $23-2$ & & & \\
\hline E. spissum & $8-7,8-10$ & & $10-3,15-6$ & \\
\hline E. virginicum & $8-6$ & & $10-4$ & \\
\hline Gramineae & 19-2 & & & $31-9$ \\
\hline Herbacae & $\begin{array}{l}13-7,13-8 \\
14-11,17-8 \\
17-10,17-11,21-9\end{array}$ & & & $\begin{array}{l}19-3,27-12, \\
28-1\end{array}$ \\
\hline Hylocomium splendens & & $12-5,12-6$ & & \\
\hline Hypnum linbergii & & $12-8$ & & \\
\hline $\begin{array}{l}\text { Juncus effusus } \\
\text { Juniperus communis }\end{array}$ & $7-10,9-2$ & $6-1$ & $10-2$ & \\
\hline J.horizontalis & $4-2$ & & $7-1$ & \\
\hline Kalmia angustifolia & $1-3,27-3$ & $\begin{array}{l}2 \cdot 11,2 \cdot 12 \\
4-12\end{array}$ & & \\
\hline Kalmia cf. & $23-12$ & & & \\
\hline Kalmia polifolia & $4-10$ & & & \\
\hline Kalmia sp. & $30-8$ & $14-3$ & & \\
\hline Larix laricina & $4-3,4-4$ & $17-3$ & $16-10$ & $\begin{array}{l}16-4,16-5 \\
16-6,16-11 \\
20-12,21-4\end{array}$ \\
\hline Ledum groenlandicum & $\begin{array}{l}1-6,2-4 \\
3 \cdot 12,30-9\end{array}$ & $3-3,3-4$ & & \\
\hline Lignosae & $\begin{array}{l}13-2,16-8 \\
18-12,19-7\end{array}$ & $\begin{array}{l}14-9,19-6 \\
28-8\end{array}$ & & $\begin{array}{l}19-5,20-3 \\
20-8,24-7 \\
25-9,29-6\end{array}$ \\
\hline Lignosae, shrubby & $\begin{array}{l}20-4,20-5 \\
20-7,20-9\end{array}$ & & & $\begin{array}{l}21-1,25-1, \\
29-4,30-4, \\
28-2,28-3, \\
28-4,32-2\end{array}$ \\
\hline $\begin{array}{l}\text { Lycopodium sp. } \\
\text { Menyanthes trifoliata } \\
\text { Mnium affine }\end{array}$ & $8-9$ & $\begin{array}{l}31-10,31-11 \\
12 \cdot 1\end{array}$ & $9-11$ & \\
\hline Myricagale & $\begin{array}{l}1-5,2-2 \\
2-3\end{array}$ & $\begin{array}{l}3-2,5-1 \\
5-3,30-11\end{array}$ & $6-7$ & $3-10$ \\
\hline
\end{tabular}




\begin{tabular}{|c|c|c|c|c|}
\hline & $\begin{array}{l}\text { Elongated } \\
\text { structures }\end{array}$ & Leaves & Seeds & Others \\
\hline Nemopanthus mucronata & $2-6,4-7$ & & $6-10$ & \\
\hline Osmunda sp. & & & & $28-12$ \\
\hline Picea glauca & & $5-9,5-10$ & $7-3$ & \\
\hline P. mariana & $19-11$ & $\begin{array}{l}5-6,5-12 \\
15-2\end{array}$ & $6-8$ & \\
\hline Pinus banksiana & & & $7-5$ & \\
\hline P. divaricata & & $5-8$ & & \\
\hline P. resinosa & & & $7-4$ & \\
\hline P.strobus & & $5-11$ & $6-11$ & \\
\hline Pleurozium schreberi & $11-11$ & $\begin{array}{l}12-11,15-7 \\
15-8,22-8 \\
26-8\end{array}$ & & \\
\hline Polygonum lapathifolium & & & $11-8$ & \\
\hline Polypodiaceae & & & & $17-6$ \\
\hline Polytrichum sp. & $25-4$ & $12-7,25-6$ & & $25-3$ \\
\hline Potamogeton $\mathrm{sp}$ & & & $31-5$ & \\
\hline Potentilla palustris & $5-4,5-5$ & & $6-9$ & \\
\hline Pteridophytae & $\begin{array}{l}29-1,29-12 \\
30-3,30-6\end{array}$ & & & $\begin{array}{l}24-12,29-2, \\
29-3,29-5, \\
29-10,29-11, \\
30-1,30-2, \\
31-6\end{array}$ \\
\hline $\begin{array}{l}\text { Pteridophytae/ } \\
\text { Equisetum sp. }\end{array}$ & $17-2$ & & & \\
\hline Ptilium crista-castensis & $12-4$ & & & \\
\hline Rhododendron canadensis & $4-8,4-9$ & & & \\
\hline Rhynchospora alba & & & $9-12$ & \\
\hline Salix sp. & & & $16-12$ & \\
\hline Scheuchzeria palustris & $\begin{array}{l}7-11,9-3 \\
32-3,32-4\end{array}$ & $9-9$ & & \\
\hline Scirpus acutus/S. validus & $7-9,9-1$ & & $24-4$ & \\
\hline Scorpidium sp. & & & & $26-1$ \\
\hline Sphagnum sp. & $\begin{array}{l}12-9,14-8, \\
15-3,15-9 \\
15-10,15-12, \\
30-12,31-1\end{array}$ & $15-1,25-7$ & & $\begin{array}{l}22-2,22-6, \\
24-10,27-4, \\
27-6,27-7 \\
27-9,28-5 \\
30-7\end{array}$ \\
\hline Taxus canadensis & & $5-7$ & $7-2$ & \\
\hline Thuja occidentalis & $4-5,4-6$ & & $7-6$ & \\
\hline Tomenthypnum nitens & & $12-10$ & & \\
\hline Tsuga canadensis & & & $6-12$ & \\
\hline Typha sp. & $8-1,9-5$ & & & \\
\hline Vaccinium angustifolium & $\begin{array}{l}1-4,1-10 \\
1-11,1-12 \\
2-1\end{array}$ & $3-1$ & & \\
\hline$V$. macrocarpon & $2-5$ & $3-7,3-8$ & & \\
\hline V. myrtilloides & & & $6-4$ & \\
\hline V. oxycoccos & $1-7,2-5$ & $3-5,3-6$ & $6-3$ & \\
\hline Vaccinium sp. & $\begin{array}{l}13-11,13-12, \\
30-10\end{array}$ & & & \\
\hline V.uliginosum & & & $6-5$ & \\
\hline
\end{tabular}



